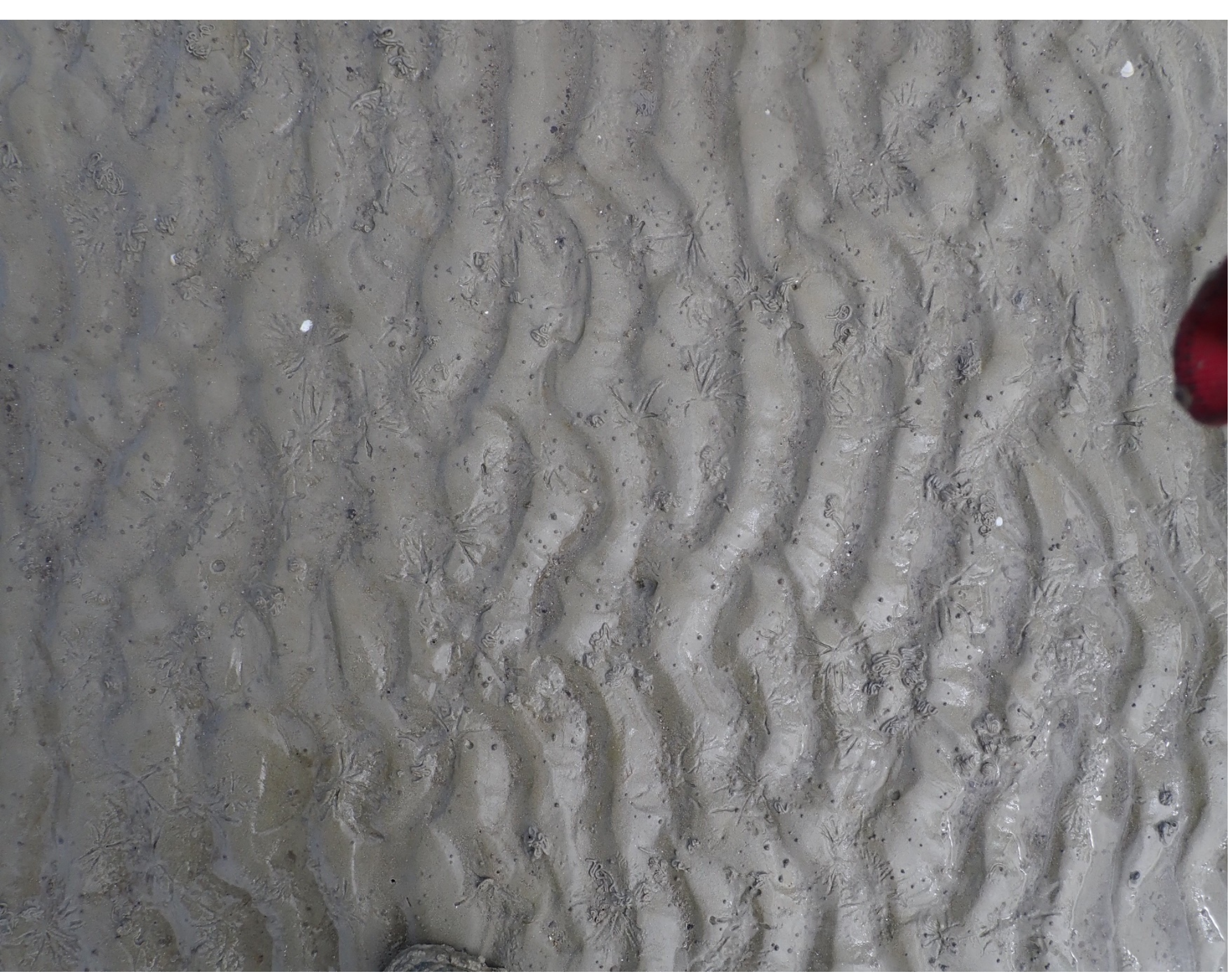

\title{
T0 monitoring bodemdieren en slibgehalte bij het schor van Bath
}




\section{T0 monitoring bodemdieren en slibgehalte bij het schor van Bath}

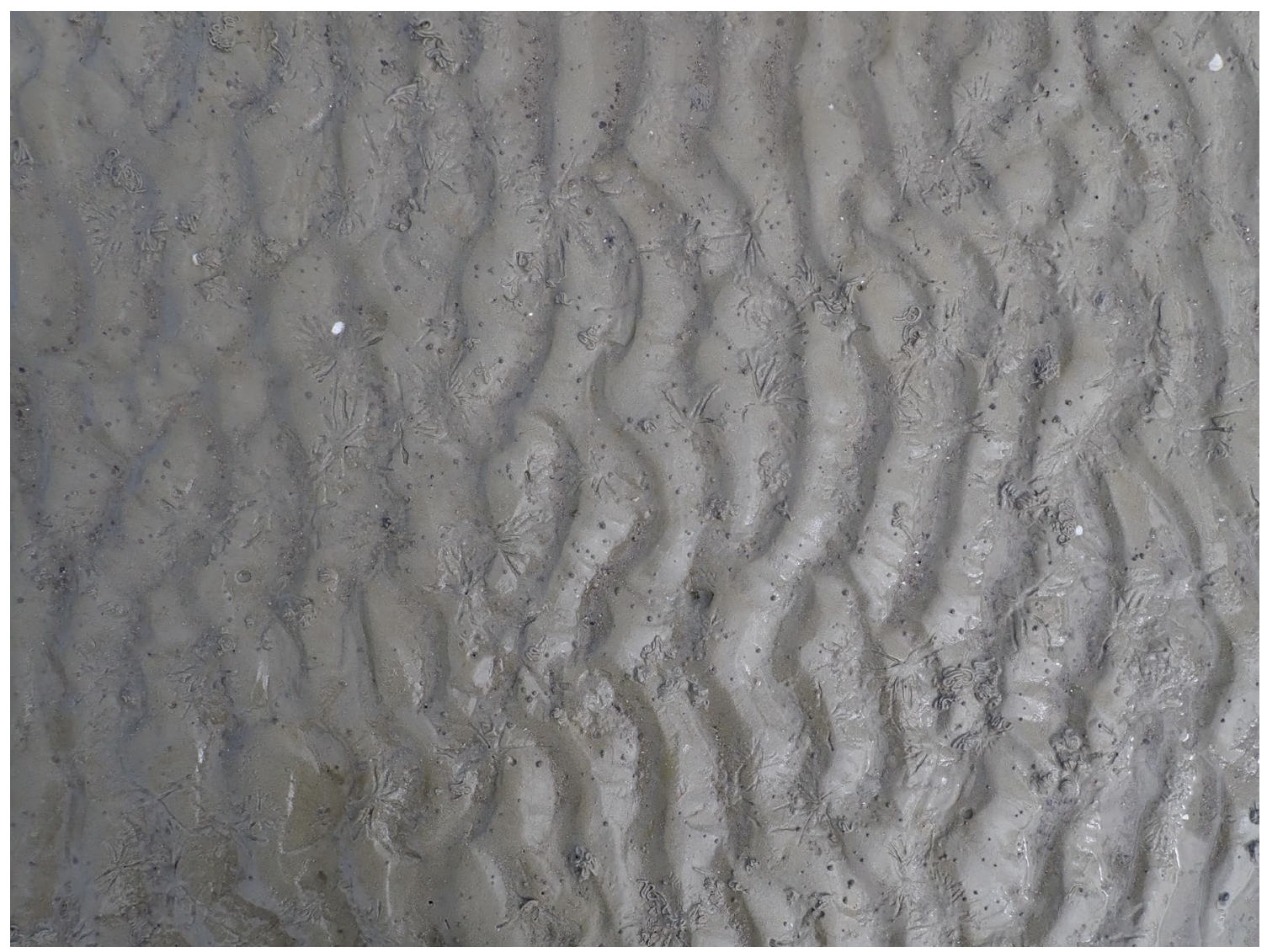




\section{(c) Wageningen Marine Research}

Wageningen Marine Research, instituut binnen de rechtspersoon Stichting

Wageningen Research, hierbij vertegenwoordigd door Dr. M.C.Th. Scholten, Algemeen directeur

KvK nr. 09098104,

WMR BTW nr. NL 8113.83.696.B16.

Code BIC/SWIFT address: RABONL2U

IBAN code: NL 73 RABO 0373599285
Wageningen Marine Research aanvaardt geen aansprakelijkheid voor gevolgschade, noch voor schade welke voortvloeit uit toepassingen van de resultaten van werkzaamheden of andere gegevens verkregen van Wageningen Marine Research. Opdrachtgever vrijwaart Wageningen Marine Research van aanspraken van derden in verband met deze toepassing.

Alle rechten voorbehouden. Niets uit deze uitgave mag weergegeven en/of gepubliceerd worden, gefotokopieerd of op enige andere manier gebruikt worden zonder schriftelijke toestemming van de uitgever of auteur. 
Keywords: intergetijdengebied, Westerschelde, slibgehalte, droogvalduur, bodemdieren, buitendijkse maatregelen.

\author{
Opdrachtgever: Provincie Zeeland \\ T.a.v.: Eva Haverkorn \\ Abdij 6 \\ 4331 BK Middelburg
}

Dit rapport is gratis te downloaden van https://doi.org/10.18174/523394

Wageningen Marine Research verstrekt geen gedrukte exemplaren van rapporten.

Wageningen Marine Research is ISO 9001:2015 gecertificeerd.

Foto omslag: sporen van hoge dichtheden van de platte slijkgaper Scrobicularia plana op het slik van Bath 



\section{Inhoud}

$\begin{array}{lr}\text { Samenvatting } & 7\end{array}$

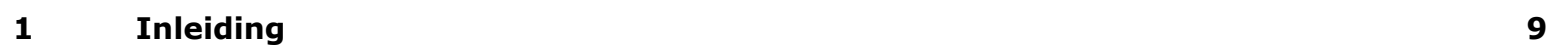

$\begin{array}{lll}1.1 & \text { Achtergrond } & 9\end{array}$

$\begin{array}{llr}1.2 & \text { Probleemstelling } & 9\end{array}$

2 Doelstelling $r$

$\begin{array}{llr}3 & \text { Afbakening } & 10\end{array}$

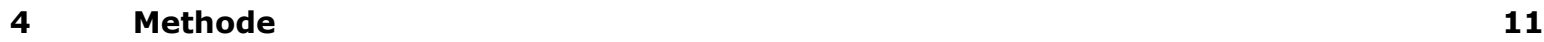

4.1 T0 Monitoring $\quad 11$

4.1.1 Gebiedsbeschrijving 12

$\begin{array}{ll}4.1 .2 & \text { Locatie keuze bemonstering } \\ \end{array}$

4.2 Bodemdieren $\quad 15$

4.2.1 Dichtheidbepaling 15

4.2.2 Biomassabepaling 15

4.2.3 Schelplengtes en leeftijdsbepaling $\quad 15$

$\begin{array}{ll}\text { 4.2.4 Benthische indicatoren } & 15\end{array}$

$\begin{array}{ll}4.3 \text { Sediment } & 16\end{array}$

4.4 Bodemdieren in relatie tot ecotopen 16

4.5 Vergelijking met MWTL $\quad 16$

$\begin{array}{lll}4.6 & \text { Statistiek } & 16\end{array}$

$\begin{array}{llr}5 & \text { Resultaten } & 17\end{array}$

$\begin{array}{llr}5.1 & \text { Bodemdieren } & 17\end{array}$

$\begin{array}{lll}5.1 .1 & \text { Soortenrijkdom } & 17\end{array}$

$\begin{array}{lll}5.1 .2 & \text { Dichtheid } & 17\end{array}$

$\begin{array}{lll}5.1 .3 & \text { Biomassa } & 19\end{array}$

$\begin{array}{lll}5.1 .4 & \text { Schelplengtes } & 20\end{array}$

$\begin{array}{lll}5.2 & \text { Sediment } & 21\end{array}$

$\begin{array}{lll}5.3 & \text { Relaties } & 23\end{array}$

5.3.1 Soortenrijkdom, dichtheid en biomassa in relatie tot sedimentsamenstelling. 23

5.3.2 Soortenrijkdom, dichtheid en biomassa in relatie tot droogvalduur $\quad 24$

5.3.3 Bodemdieren in relatie tot ecotopen $\quad 26$

5.4 Vergelijking met MWTL bodemdieren $\quad 26$

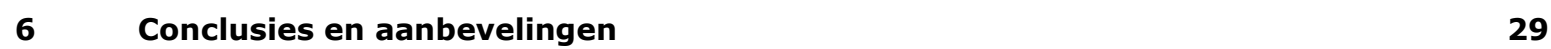

$\begin{array}{lll}6.1 & \text { Aanbevelingen vervolgmonitoring } & 32\end{array}$

$\begin{array}{llr}7 & \text { Kwaliteitsborging } & 34\end{array}$

$\begin{array}{lr}\text { Literatuur } & 35\end{array}$

$\begin{array}{lll}\text { Bijlage } 1 & \text { Coördinaten bemonsteringslocaties } & 36\end{array}$

$\begin{array}{llr}\text { Bijlage } 2 & \text { Conversiefactoren } & 37\end{array}$

$\begin{array}{lll}\text { Bijlage } 3 & \text { Verspreidingskaarten dichtheden en biomassa per soort } & 38\end{array}$ 


\section{Samenvatting}

Als onderdeel van het natuurpakket Westerschelde (NPW) wil de Provincie Zeeland getijdennatuur herstellen in de Westerschelde middels een aantal buitendijkse maatregelen, dit zijn maatregelen die in het estuarium zelf worden uitgevoerd. Deze maatregelen richten zich met name op uitbreiding en kwaliteitsverbetering van laagdynamische natuur middels aanleg of ophoging van strekdammen of het aanpassen van geulen. Eén van de kansrijke projecten is de ontwikkeling van het buitengebied bij Bath. De doelstelling is het creëren van laagdynamisch zandig tot matig slibrijk intergetijdengebied, met ervoor een laagdynamisch ondiep watergebied. Het gebied bij Bath wordt in zijn huidige toestand gekenmerkt door een steeds verder bloot spoelende veenbank nabij de laagwaterlijn. De uitgangssituatie wordt derhalve (geheel of grotendeels) als hoogdynamisch, ecologisch arm gebied omschreven. Door de aanleg van strekdammen wordt getracht de hydrodynamiek te verlagen waardoor slib en fijn zand kan sedimenteren op en tussen de klei- en veenbanken.

Om de effecten van deze maatregel, middels monitoring, te kunnen evalueren, is het van belang om goed de huidige situatie (zogen. referentiesituatie of nul-situatie) te kennen. Doel van dit project was het opstellen en uitvoeren van een monitoring op bodemdieren en sedimentsamenstelling om de nulsituatie (TO) in kaart te brengen. De bodemdiergemeenschap is uitgedrukt op basis van de dichtheid, de biomassa en de soorten-samenstelling per ecotoop, en de relatie met hoogteligging en sedimentsamenstelling is onderzocht. De resultaten geven de ecologische toestand in het najaar van 2019 van het gebied bij Bath weer voor bodemdieren, vóór de aanleg van de strekdammen. Dit dient als uitgangspunt voor verandering in kwaliteit in de jaren volgend na aanleg van de strekdammen.

In het najaar van 2019 heeft Wageningen Marine Research een bodemdier- en sedimentbemonstering uitgevoerd op het slik bij Bath op 44 locaties langs zes dwarsraaien die lopen van de schorrand tot de laagwaterlijn. Het intergetijdengebied bij Bath bestaat voor het merendeel uit fijnzandig tot slibrijk sediment en heeft gemiddeld een mediane korrelgrootte van $107.7 \pm 59.6 \mu \mathrm{m}$ en een slibgehalte van $24.0 \pm 23.4 \%$. In totaal werden 36 verschillende bodemdiertaxa aangetroffen. Op alle bemonsterde locaties werden bodemdieren aangetroffen. Soortenrijkdom is gemiddeld $7.8 \pm 0.3$ taxa per bemonsterd station. Totale dichtheden en totale biomassa per locatie verschillen ruimtelijk binnen het gebied, variërend tussen 84 en 24446 ind. $\mathrm{m}^{-2}$ en 0.01 en $67.57 \mathrm{~g} \mathrm{AFDW} \mathrm{m}^{-2}$. De totale dichtheid neemt toe richting de hogere, slibrijke gebieden. De totale biomassa laat geen relatie zien met sedimentsamenstelling. In de klei- en veenbanken komen heel wat soorten voor, en er zijn geen significante verschillen in soortenrijkdom, dichtheid en biomassa vastgesteld in het hardsubstraat (kleien veenbanken) ten opzichte van de andere aanwezige ecotopen binnen het gebied. Wel zijn dichtheden en biomassa's relatief laag in deze gebieden.

Tijdens de T0-monitoring zijn drie exoten gevonden: twee schelpdieren, de brakwaterkorfschelp Potamocorbula amurensis en de Amerikaanse strandschelp Mulinia lateralis, en de Oostzeegroenworm Marenzelleria neglecta. Deze kwamen met name voor in het gebied tussen de toekomstige strekdammen (gebied met een droogvalduur van $50 \%$ of minder). P. amurensis werd aangetroffen in de klei- en veenbanken en op schelpenbanken.

In tegenstelling tot parameters zoals sediment hoogte, sediment samenstelling en vogels welke jaarlijks gemonitord zullen worden na aanleg van de strekdammen staat een bodemdierbemonstering alleen gepland voor T1 en T5, 1 jaar (2021) en 5 jaar (2026) na aanleg. Door eens per vijf jaar de bodemdieren te bemonsteren in combinatie met grote jaar-op-jaar variaties verkrijg je geen inzicht in de ontwikkeling in de tijd van het voedselaanbod. Ons advies is om minstens één extra bemonsterjaar toe te voegen om inzicht te verkrijgen in deze ontwikkeling. De geplande T1 en T5, 1 jaar (2021) en 5 jaar (2026) na aanleg van de strekdammen, kan met enkele kleine aanpassingen op eenzelfde manier uitgevoerd worden als de T0. De T0-monitoring geeft een goed beeld van de ruimtelijke spreiding van soorten en sedimentsamenstelling binnen het gebied. De locaties van de bemonsteringspunten langs de raaien zijn op basis van de droogvalduur bepaald. Dit kan van jaar tot jaar verschillen door morfologische veranderingen, mede door de aanleg van de strekdammen. Het bepalen van de bemonsterpunten langs de raai middels droogvalduur heeft de voorkeur boven stationaire punten, omdat de kans bestaat bij stationaire punten dat een gradiënt in droogvalduur verloren gaat wanneer het gebied morfologisch 
verandert. Afhankelijk van de ontwikkeling tussen de strekdammen en op basis van een visuele inspectie kan besloten worden om extra bemonsteringslocaties toe te voegen.

In een vervolgmonitoring adviseren wij de stations gelegen op de $10 \%$ en $20 \%$ droogvalduur niet te voet te bemonsteren, maar vanuit een boot, mits haalbaar. Op de $10 \%$ en $20 \%$ droogvalduur bevinden zich oude afgravingen die soms meer dan $50 \mathrm{~cm}$ diep zijn. Wanneer deze geulen naar verwachting opslibben is het een verraderlijk gebied om te voet te betreden.

Tot slot is het belangrijk de biologische monitoring (zowel bodemdieren maar ook het gebruik van het gebied door vogels) te koppelen aan een gedegen morfologische (sedimentatie/erosie, sedimentsamenstelling) en hydrologische (stroming, golven) monitoring, incl. modellering. Het monitoringsplan voorziet in het monitoren van deze parameters. 


\section{Inleiding}

\subsection{Achtergrond}

De Westerschelde is een Natura 2000-gebied dat van internationaal belang is voor een groot aantal vogels. Met name de bij eb droogvallende slikken en zandplaten zijn essentiële foerageerhabitats voor tienduizenden steltlopers waaronder scholeksters, wulpen, bonte strandlopers en zilverplevieren. De aantallen vogels die van de Westerschelde gebruik maken, worden deels bepaald door landelijke en internationale trends, maar ook door factoren binnen de Westerschelde. In de Westerschelde is de afgelopen decennia de dynamiek in het watersysteem sterk toegenomen. De stroomsnelheden en getijdenvolumes zijn toegenomen waardoor het evenwicht tussen erosie en sedimentatie is verstoord. Daardoor zijn de afgelopen jaren verschillende kenmerkende leefgebieden in oppervlakte veranderd. Het oppervlak van de geulen is afgenomen met 1.5\% tussen 2010 en 2015 . Tussen 2010 en 2011 is het intergetijdengebied toegenomen met 3\% als gevolg van het storten van baggermateriaal op een aantal plaatranden. Hierdoor is de oppervlakte hoogdynamisch intergetijdengebied afgenomen en de oppervlakte laagdynamisch intergetijdengebied toegenomen. Na 2011 is het oppervlak constant, maar worden de intergetijdengebieden wel steiler en hoger (T2015, Barneveld et al. 2018). Verschillende vogelsoorten zijn afhankelijk van deze getijdennatuur. In het licht van de instandhoudingsdoelen die zijn opgenomen in het Aanwijzingsbesluit Natura 2000 Westerschelde \& Saeftinghe (2010) en het Wijzigingsbesluit (2012) ligt er een herstelopgave voor het behoud van de bestaande natuurwaarden en waar mogelijk het herstellen en veilig stellen van deze natuurwaarden in de Westerschelde. In het kader van deze herstelopgave heeft de provincie Zeeland, op verzoek van het Rijk, een taakstelling voor natuurontwikkeling in de Westerschelde. In het verdrag, betreffende de uitvoering van de Ontwikkelingsschets 2010 Schelde-estuarium, staat dat in totaal 600 hectare estuariene natuur (schorren en slikken) aan de Nederlandse zijde (Westerschelde) moet worden gerealiseerd. Dit zogenaamde Natuurpakket Westerschelde omhelst de uitbreiding van de estuariene natuur (schorren en slikken) met 600 hectare op drie locaties: de Hedwigepolder, natuurgebied het Zwin en het Middengebied van Zeeuws-Vlaanderen met onder andere Perkpolder, Waterdunen en een aantal buitendijkse maatregelen. De Hedwigepolder en het Zwin zijn onderdeel van de Scheldeverdragen tussen Nederland en Vlaanderen.

\subsection{Probleemstelling}

Als onderdeel van het NatuurPakket Westerschelde (NPW) wil de Provincie Zeeland getijdennatuur herstellen in de Westerschelde middels een aantal buitendijkse maatregelen, dit zijn maatregelen die in het estuarium zelf worden uitgevoerd. Deze maatregelen richten zich met name op uitbreiding en kwaliteitsverbetering van laagdynamische natuur middels aanleg van strekdammen of het aanpassen van geulen. Eén van de kansrijke projecten is de ontwikkeling van het buitendijkse gebied bij Bath (Figuur 1). Bath is geselecteerd als één van de vijf gebieden geschikt voor dit type van natuurherstel in de Westerschelde. Thans gaat het om: Baalhoek en Knuitershoek (gerealiseerd), Bath en Ossenisse (in uitvoering) en Zimmerman (in voorbereiding). In de gebieden Baalhoek en Knuitershoek zijn in 2017 reeds strekdammen aangelegd en wordt middels het project Buitendijkse Maatregelen de uitbreiding en kwaliteitsverbetering van laagdynamische natuur gemonitord (Wiesenborn et al, 2019).

Zoals beschreven staat in het Monitoringsplan Buitendijkse Maatregelen bij Bath (Provincie Zeeland) is de doelstelling het creëren van laagdynamisch zandig tot matig slibrijk intergetijdengebied, met ervoor een laagdynamisch ondiep watergebied. Volgens dit monitoringsplan wordt het gebied in zijn huidige toestand gekenmerkt door een steeds verder bloot spoelende veenbank. De uitgangssituatie wordt derhalve (geheel of grotendeels) als hoogdynamisch, ecologisch arm gebied omschreven. Door de aanleg van strekdammen wordt getracht de hydrodynamiek te verlagen waardoor slib en fijn zand kan sedimenteren op en tussen de klei- en veenbanken (Figuur 2). Om de effecten van deze maatregel, middels monitoring, te kunnen evalueren, is het van belang om goed de huidige situatie (zogen. referentiesituatie of nul-situatie) te kennen. Het meten van de kwaliteit van de natur is geen eenvoudige opgave. Het bepalen van het vertrekpunt, de huidige toestand of nul-situatie, en de gewenste kwaliteitsverbetering, dient zorgvuldig te gebeuren. 


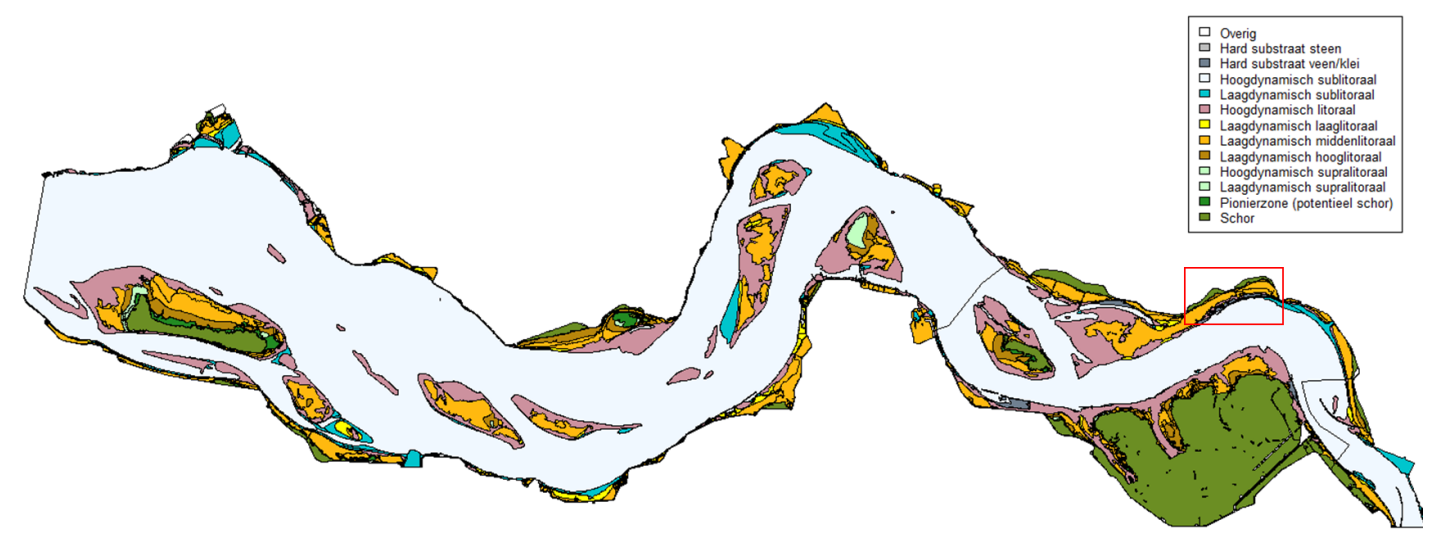

Figuur 1. Ecotopenkaart Westerschelde 2016 met aanduiding (rood kader) van het slikken- en schorrengebied bij Bath.

\section{Doelstelling}

Om een goede uitspraak te kunnen doen over de kwaliteitsverbetering van laagdynamische natuur na aanleg van de buitendijkse inrichtingsmaatregelen bij Bath is inzicht nodig in de huidige ecologische toestand. Daarom is dit project gestart met als doel het opstellen en uitvoeren van een monitoring op bodemdieren en sedimentsamenstelling om de nul-situatie (TO) in kaart te brengen. Bodemdieren vormen een essentieel onderdeel van het ecosysteem. Ze zijn een voedselbron voor vogels en vissen en beïnvloeden de bodem- en waterkwaliteit door de uitwisseling van nutriënten en zuurstof tussen de bodem en de waterkolom. Naast omgevingsfactoren zoals zoutgehalte, droogvalduur en hydrodynamiek is de korrelgrootteverdeling en het slibgehalte van de bodem een bepalende factor voor het voorkomen van bodemdieren. De meeste bodemdieren hebben een brede tolerantie in relatie tot sedimentsamenstelling, maar er zijn ook gespecialiseerde soorten die gebonden zijn aan slib. Slikrijke bodems kunnen tevens nutriënten beter vast houden en hebben doorgaans een hoger percentage aan organisch materiaal. De bodemdiergemeenschap is uitgedrukt op basis van de dichtheid, de biomassa en de soortensamenstelling per ecotoop, en de relatie met hoogteligging en sediment samenstelling is onderzocht. De resultaten geven de ecologische toestand in het najaar van 2019 van het gebied bij Bath weer voor bodemdieren, vóór de aanleg van de strekdammen. Dit dient als uitgangspunt voor verandering in kwaliteit in de jaren volgend na aanleg van de strekdammen. Tevens is er een advies gegeven voor de door de Provincie Zeeland geplande vervolgbemonstering (T1: 1 jaar na aanleg van de strekdammen en T5: 5 jaar na aanleg van de strekdammen).

\section{Afbakening}

Deze studie brengt de huidige ecologische toestand van de slikken van Bath in kaart, met een focus op de bodemdieren en de sedimentsamenstelling, op basis van een bemonstering in het najaar van 2019. Beide parameters worden verwacht te veranderen door de aanleg van de strekdammen en zijn daarom goede indicatoren om de maatregel te evalueren.

Zowel de bodemdieren- als de sedimentsamenstelling worden beïnvloed door de heersende hydrodynamiek, welke door de strekdammen zal worden beïnvloed. Metingen naar hydrodynamiek vormden geen onderdeel van dit project, maar in 2017 is reeds een 13-uurs stroommeting uitgevoerd in de geul voor de slikken bij Bath en zijn stroomsnelheidsmetingen op 18 vaste punten op het slik, verdeeld over negen raaien, gedurende één maand uitgevoerd door RWS (vanaf 22 maart 2017). In de aanbevelingen wordt ingegaan op het belang van deze stroomsnelheidsmetingen na aanleg van de strekdammen (voorzien in het door de provincie opgestelde monitoringsprogramma) in relatie tot het voorkomen van bodemdieren. Daarnaast is door WMR in 2016 een ecomorfologische quickscan uitgevoerd die tevens onderdeel vormt van de T0-situatie en in deze studie gebruikt is bij het opstellen van de monitoring (Ysebaert en Brummelhuis, 2016). 


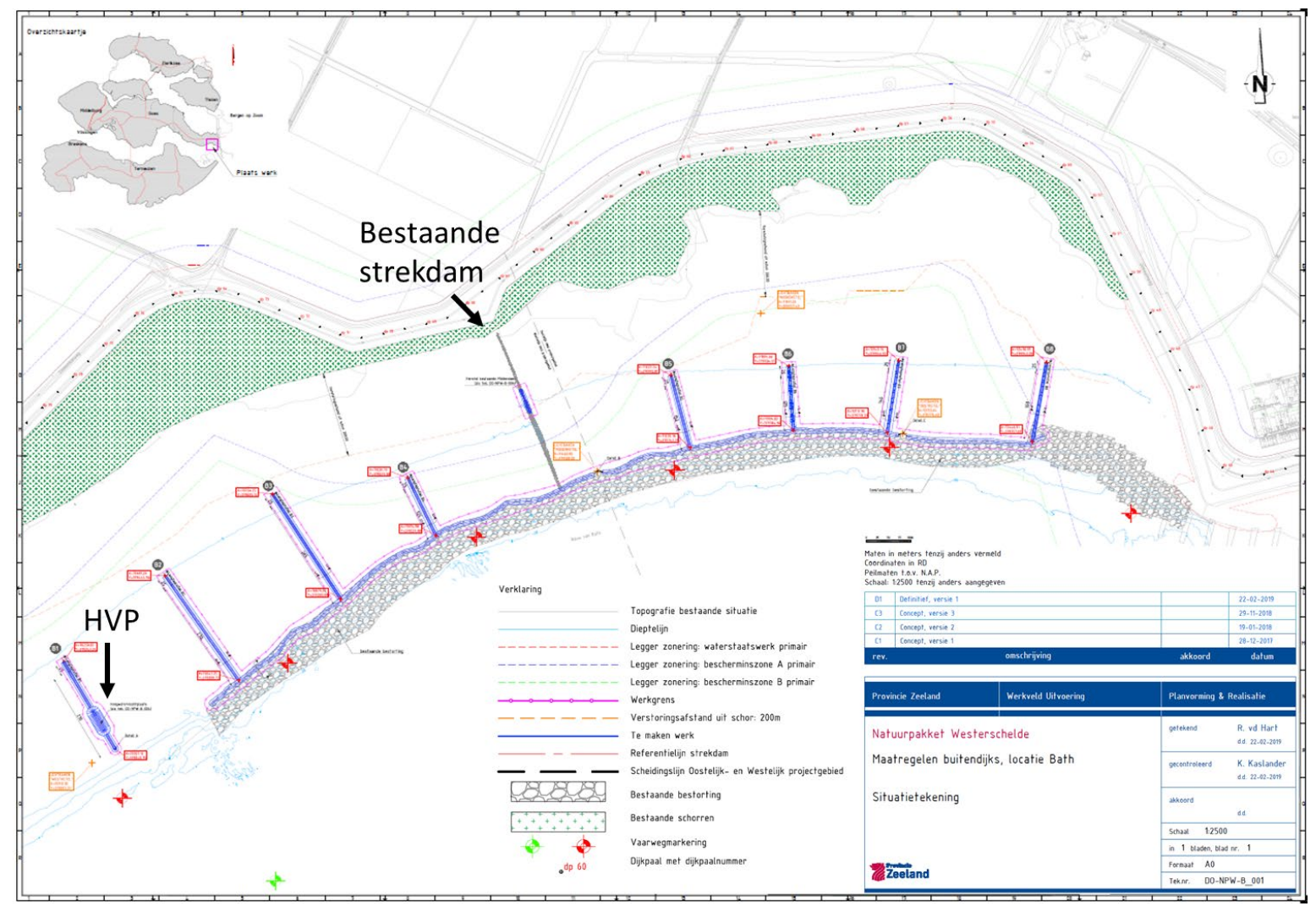

Figuur 2. Overzicht van de geplande werkzaamheden projectlocatie Bath. De blauwe lijnen geven de nieuw aan te leggen strekdammen weer. Op de meest westelijke strekdam bevindt zich een hoogwatervluchtplaats (HVP). De bestaande strekdam die het gebied in een westelijk en oostelijk deel opdeelt wordt halverwege hersteld (Provincie Zeeland).

\section{Methode}

Om te achterhalen wat de nul-situatie (TO) voor bodemdieren en de sedimentsamenstelling is, hebben we een T0 monitoringsplan opgesteld, rekening houdend met de huidige gradiënten in omgevingsfactoren en de verwachte veranderingen na aanleg van de strekdammen.

Deze monitoring dient antwoord te geven op de volgende vragen:

1. Wat is de huidige kwaliteit van het intergetijdengebied bij Bath uitgedrukt in termen van soortenrijkdom, biomassa, en dichtheid aan bodemdieren. Welke gebieden/ecotopen zijn het rijkst/armst aan bodemdieren in de huidige situatie?

2. Wat is de huidige sedimentsamenstelling en het slibgehalte in het intergetijdengebied bij Bath en hoe varieert dit binnen het gebied?

\subsection{T0 Monitoring}

Voor het opstellen van het monitoringsplan is gebruik gemaakt van de ecomorfologische quickscan uitgevoerd door WMR in 2016 (Ysebaert en Brummelhuis, 2016), de verwachte bodemontwikkeling (zie Dam \& van de Rest, 2015 alternatief 3A (uitvoeringsvariant), na 18 jaar) en de ecotopenkaart uit 2016. Tijdens het opstellen van de T0 monitoring en het uitvoeren van de analyses is gebruik gemaakt van de ecotopenkaart uit 2016 omdat de ecotopenkaart uit 2018 nog niet voor handen was. 


\subsubsection{Gebiedsbeschrijving}

Het intergetijdengebied bij Bath toont een gradiënt in sedimentsamenstelling langsheen de hoogtegradiënt (van meer slibrijk sediment in het hoog en middenhoog litoraal naar meer fijn zandig en zandig sediment lager in het litoraal) en langs een oost naar west gradiënt (van meer fijn zandig/zandig sediment in het westen naar slibrijk sediment in het oosten) (Ysebaert \& Brummelhuis, 2016). Deze gradiënten zijn tevens zichtbaar in de ecotopenkaart van 2016 (Figuur 3). In het laag litoraal bevinden zich klei- en veenbanken en schelpenbanken (zie figuur 5 in Ysebaert en Brummelhuis, 2016). De reeds aanwezige strekdam het gebied op in een westelijk en oostelijk deel (zie Figuur 2). Figuur 3 toont de ecotopenkaart van 2016 en 2018. Hierin zijn de steeds verder bloot-spoelende klei- en veenbanken goed zichtbaar.
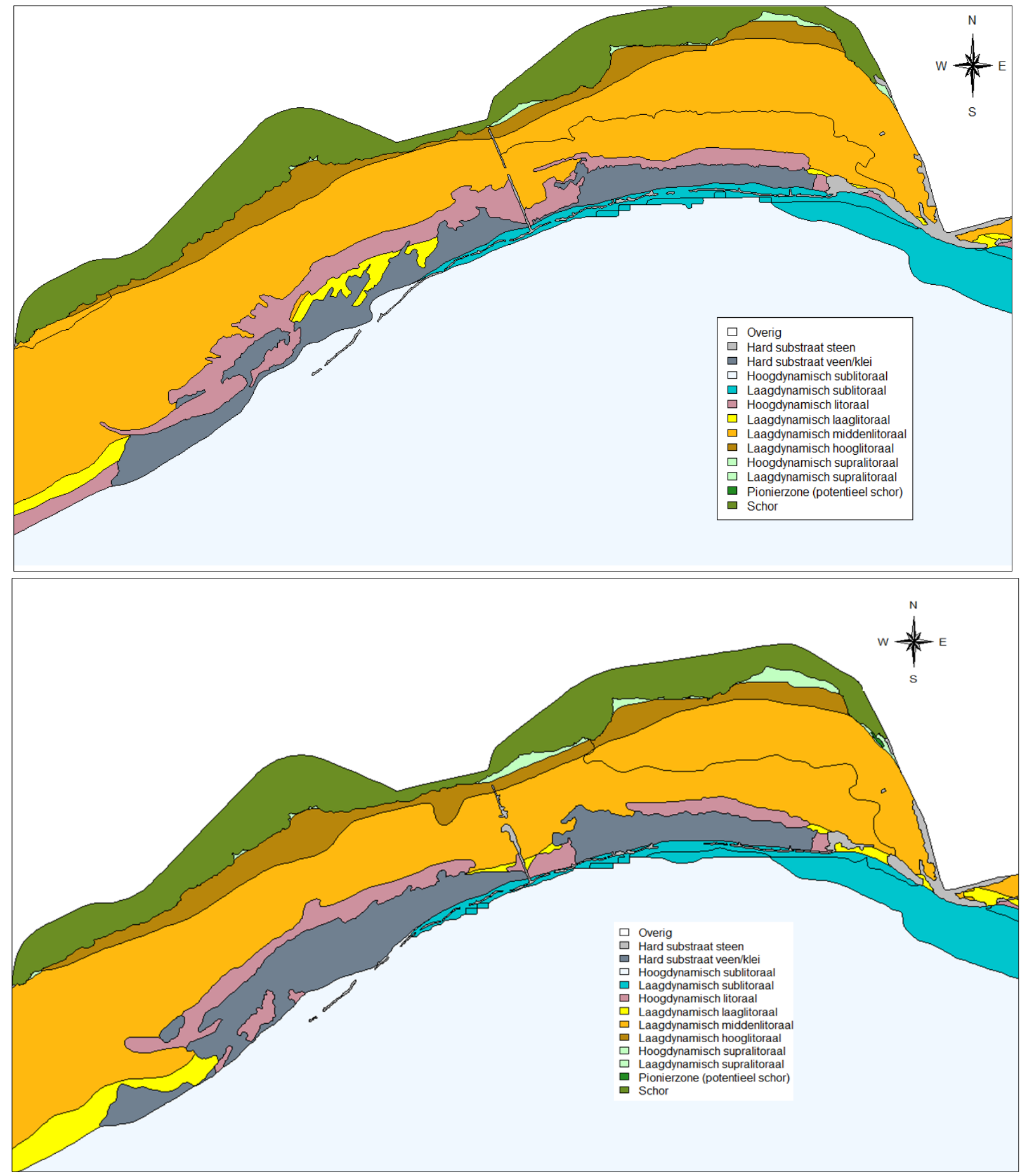

Figuur 3. Ecotopenkaart 2016 (boven) en 2018 (onder) van het slikken- en schorrengebied bij Bath. 


\subsubsection{Locatie keuze bemonstering}

Om variatie langs de hoogtegradiënt goed te ondervangen is gekozen voor een bemonstering langs zes dwarsraaien die lopen van de schorrand tot de laagwaterlijn (Figuur 4). Verschillen tussen het westelijke en oostelijke deel worden ondervangen door aan weerszijden van de huidige strekdam drie dwarsraaien te plaatsen. Het gebied rondom de bestaande strekdam wordt niet bemonsterd omdat veranderingen door aanleg van de nieuwe strekdammen mogelijk onder invloed staan van de bestaande strekdam. Grootste morfologische veranderingen worden aan het uiteinde van de strekdammen, rond de Om NAP lijn verwacht (Figuur 5) (Dam \& van de Rest, 2015). De bemonsteringsstrategie houdt hier rekening mee en besteedt extra aandacht aan dit gebied. Om variatie tussen de strekdammen te ondervangen is gekozen voor extra monsterstations loodrecht op de raai op de 0m NAP (50\% droogvalduur) lijn.

Het uiteindelijke ontwerp bestaat dus uit drie raaien ten westen (1, 2 en 3 ) en drie raaien ten oosten $(4,5$ en 6$)$ van de bestaande strekdam (Figuur 4). De raaien liggen in het midden van de geplande strekdammen, loodrecht op de geulwandbestorting, parallel georiënteerd aan de strekdammen. Per raai zijn zes locaties geselecteerd op basis van de droogvalduur, een belangrijke sturende parameter voor het voorkomen van bodemdieren. Figuur 4 toont de zes raaien met bemonsterpunten op 10, 20, 40, 50, 70 en $80 \%$ droogvalduur (dvd). De kale klei/veenbanken bevinden zicht op -2 m NAP ( $10 \%$ dvd). De punten op 10, 20, 40 en 50\% dvd bevinden zich tussen de toekomstige strekdammen. Op de $50 \%$ droogvalduurlijn van de raaien 2 en 5 liggen extra punten loodrecht op de raai om variatie tussen de strekdammen te ondervangen (Figuur 4). Middels de op droogvalduur gekozen bemonsterpunten ondervangen we ook variatie in de aanwezige ecotopen (Tabel 1). In totaal zijn 44 stations (Bijlage 1) bemonsterd om de variatie in het gebied te ondervangen. De T0 bemonstering is uitgevoerd op 3 september 2019.

Tabel 1. Aantal bemonsterde stations per ecotoop, op basis van de ecotopenkaart uit 2016.

\begin{tabular}{lr}
\hline Ecotoop & $\mathbf{n}$ \\
\hline Hardsubstraat (kale klei/veenbanken) & 10 \\
Hoogdynamisch litoraal & 10 \\
Laagdynamisch laaglitoraal & 1 \\
Laagdynamisch middenlitoraal & 18 \\
Laagdynamisch hooglitoraal & 5 \\
\hline
\end{tabular}




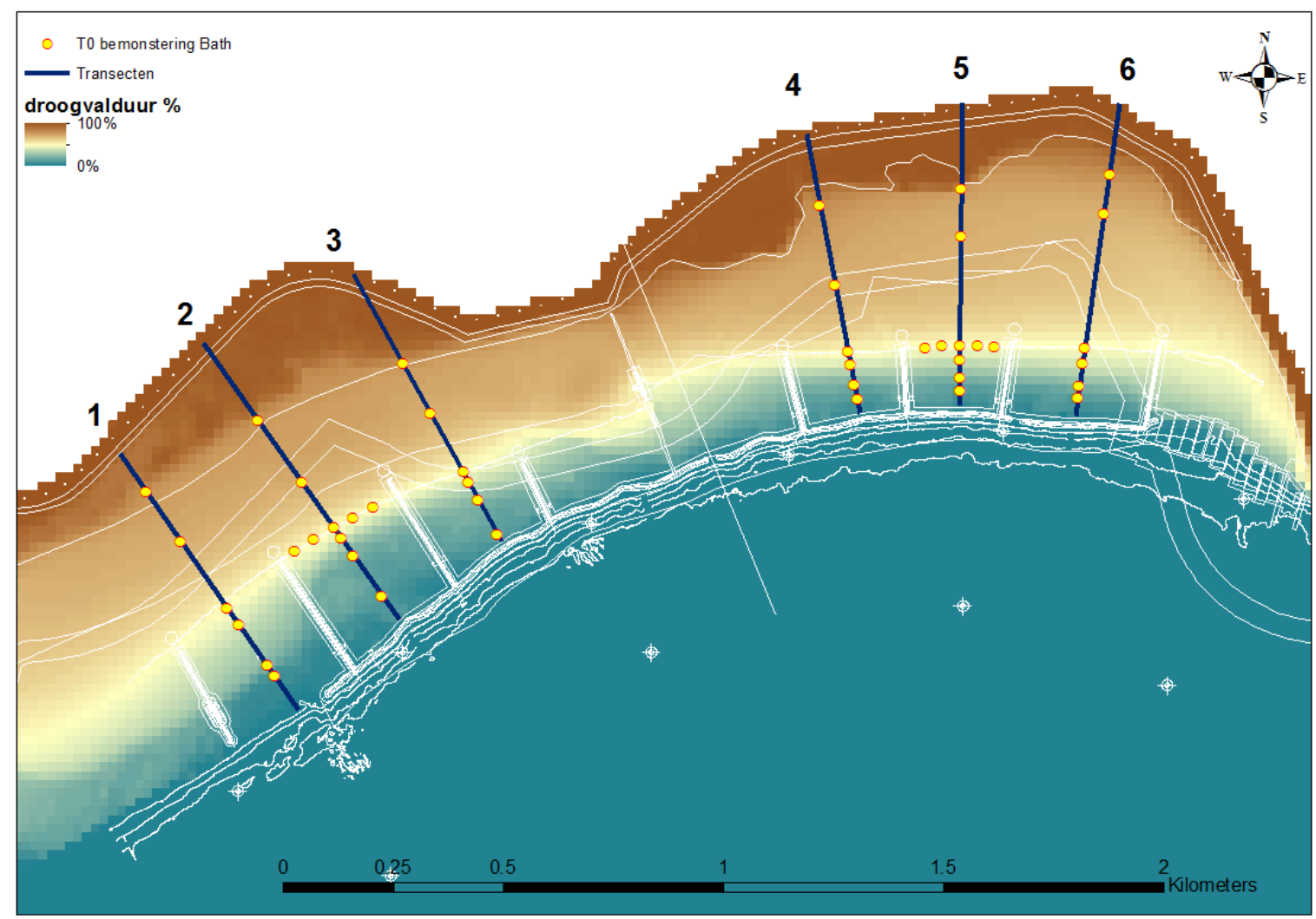

Figuur 4. Droogvalduurkaart (2016) met de 44 bemonsteringslocaties (gele stippen) gelegen op zes raaien (donkerblauwe lijnen) in het intergetijdengebied bij Bath. Drie raaien liggen in het oostelijk deel en drie in het westelijk deel. Per raai bevinden de bemonsteringslocaties zich op 10, 20, 40, 50, 70 en 80\% droogvalduur. Op raai 2 en 5 zijn bij 50\% droogvalduur extra bemonsteringslocaties loodrecht, geplaatst om de variatie tussen de toekomstige strekdammen te ondervangen.

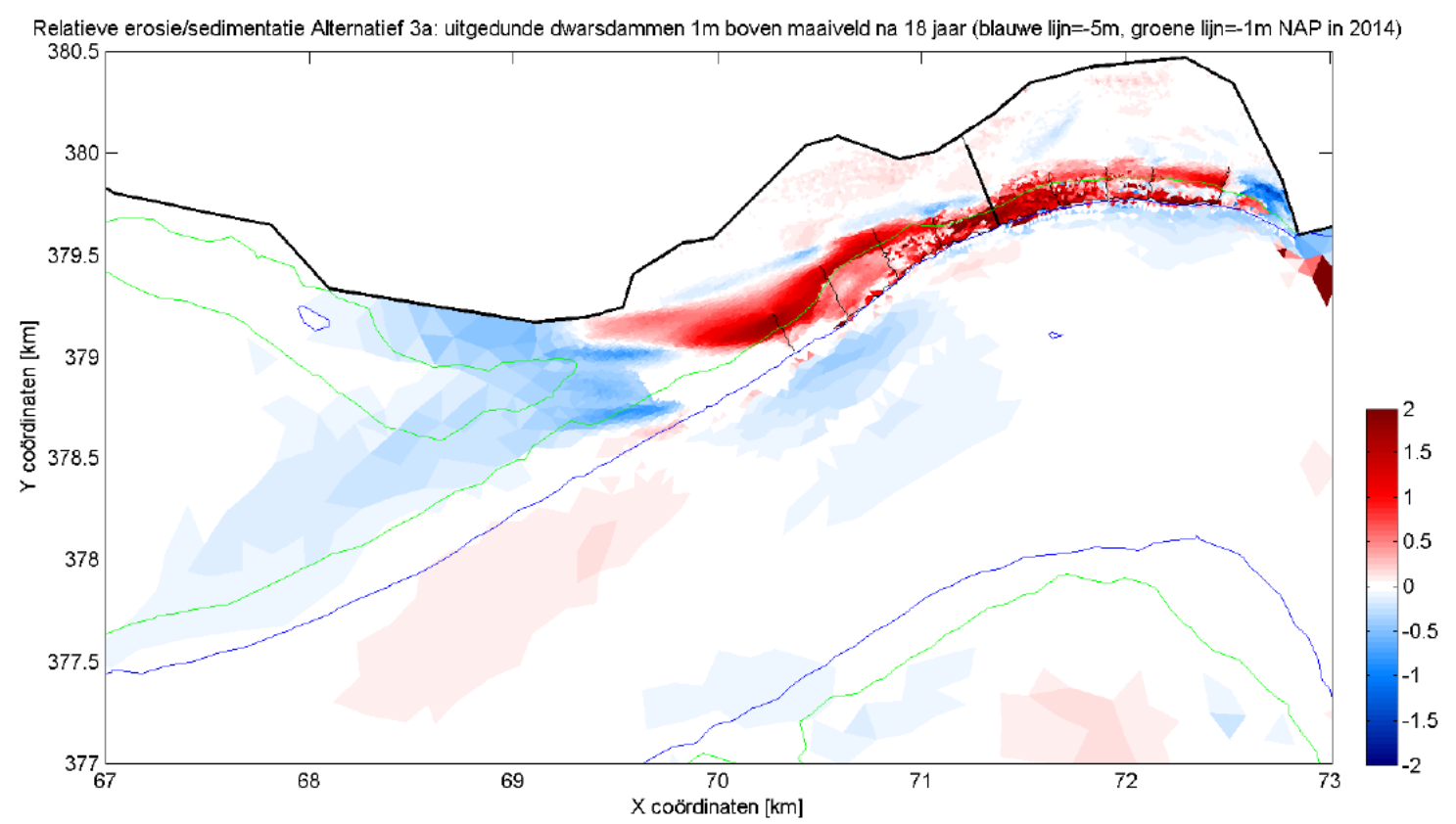

Figuur 5. Relatieve bodemontwikkeling (in meters) voor alternatief $3 \mathrm{~A}$ na achttien jaar (Dam \& van de Rest, 2015). De blauwe lijn geeft de -1m NAP diepte lijn weer. De groene lijn de 0m NAP diepte lijn. 


\subsection{Bodemdieren}

In het najaar van 2019 heeft Wageningen Marine Research een bemonstering van de bodemdieren uitgevoerd op de 44 locaties. Middels coördinaten in een handheld GPS zijn de posities van de locaties bepaald in het veld. De stations zijn bemonsterd door op korte onderlinge afstand (binnen $1 \mathrm{~m}^{2}$ ) driemaal een steekbuis met een diameter van $10 \mathrm{~cm}$ te steken (totale opp. $0.0236 \mathrm{~m}^{2}$ ) tot de beoogde steekdiepte van $35 \mathrm{~cm}$. De monsters zijn, na samenvoegen van de drie deelmonsters, gespoeld op een zeef met 1 $\mathrm{mm}$ maaswijdte. Na het zeven is het residu in een monsterpot overgebracht. De pot wordt van voldoende water voorzien i.v.m. uitdroging van het monster. Direct bij terugkomst op het lab zijn de monsters gefixeerd door $\mathrm{pH}$-geneutraliseerde formaldehyde toe te voegen in de monsterpot tot een concentratie van minimaal $4 \%$ formaline. Alvorens verdere verwerking van de monsters zijn de monsters nagespoeld, gekleurd met bengaals rose en vervolgens uitgezocht. De dieren zijn uit de residuen gezocht; met het blote oog en met behulp van een binoculair.

De analyse van de bodemdieren is uitgevoerd volgens protocol E_4_102 Procedure analyse macrobenthosmonsters uitzoeken, determineren en verwerken (deze is in revisie). Tot het benthos wordt gerekend, alle levende (ongewervelde) organismen ( $\geq 1 \mathrm{~mm}$ ) die in en op de bodem leven. Alle dieren werden, zo mogelijk, tot op soortniveau gedetermineerd en de aantallen werden bepaald. Nemertea, Plathyhelminthes, Anthozoa,, Oligochaeta, Ophistobranchia, Cnidaria, werden tot op phylum, of klasse uitgezocht.

\subsubsection{Dichtheidbepaling}

Bij de verwerking van de monsters kunnen incomplete dieren (fragmenten) worden aangetroffen. Slechts fragmenten met een herkenbaar onderdeel (uniek voor een individu) zijn als individu geteld. Voor de meeste diergroepen is dat de kop (of het deel met de mond) en voor de schelpdieren is dat het slot. Wanneer van een bepaalde soort enkel fragmenten zonder kop of slot gevonden zijn, tellen die fragmenten samen voor één individu.

\subsubsection{Biomassabepaling}

Biomassa van bodemdieren wordt standaard uitgedrukt als asvrij drooggewicht (AFDW) en uiteindelijk omgerekend tot $\mathrm{g}$ AFDW per $\mathrm{m}^{2}$. AFDW is verkregen op basis van AFDW/natgewicht-conversiefactoren (zie Bijlage 2) zoals beschreven in Craeymeersch \& Escaravage (2014). Bij het bepalen van het natgewicht zijn de organismen eerst op filtreerpapier drooggedept totdat het aan het lichaam hangende vocht door het papier is opgenomen.

\subsubsection{Schelplengtes en leeftijdsbepaling}

Van alle aangetroffen individuen is de schelplengte gemeten met een digitale schuifmaat. Schelplengte is de grootste lengte van de schelp. Er zijn leeftijdsbepalingen uitgevoerd voor kokkels, maar niet voor de overige schelpdiersoorten. Gezien de lage aantallen kokkels wordt hier in de resultaten niet verder op ingegaan.

\subsubsection{Benthische indicatoren}

Gebaseerd op de bodemdiermonsters zijn een aantal biologische indicatoren gedefinieerd die gelinkt kunnen worden aan abiotische parameters (sedimentsamenstelling, droogvalduur):

(1) Soortenrijkdom, een maat voor de diversiteit (aantal verschillende taxa) van de macrofauna gemeenschap per monsterstation. Soortenrijkdom is het aantal soorten per monster.

(2) Dichtheid, het aantal individuen van een soort omgerekend naar aantal per $\mathrm{m}^{2}$.

(3) Biomassa, het totale asvrij drooggewicht in $\mathrm{g}$ per $\mathrm{m}^{2}$.

(4) Dominante, veel voorkomende soorten, zowel in termen van dichtheid als biomassa. 


\subsection{Sediment}

Voor het bepalen van het slibgehalte is op iedere locatie een vast volume van de bovenste $3 \mathrm{~cm}$ van het sediment bemonsterd middels een spuit $(3 \mathrm{~cm} \varnothing)$. Direct bij terugkomst op het lab zijn de monsters in een diepvries $\left(-20^{\circ} \mathrm{C}\right)$ geplaatst. Vervolgens zijn ze gevriesdroogd en is de korrelgrootteverdeling geanalyseerd bij het NIOZ met behulp van laserdiffractie (Malvern Particle Analyzer P2000). Hieruit wordt de mediane korrelgrootte verkregen (D50) en de verdeling grof zand, middel fijn zand, fijn zand, zeer fijn zand en slib. De slibfractie betreft de fractie $<63 \mu \mathrm{m}$.

\subsection{Bodemdieren in relatie tot ecotopen}

De ecotopenkaart van 2016 voor de Westerschelde, ingezoomd op het projectgebied Bath, laat zien dat de slikken van Bath in hoofdzaak bestaan uit laagdynamisch middelhooggelegen (DVD 25-75\%) litoraal. De bemonsteringslocaties lagen in het hardsubstraat (kale klei/veenbanken) $(n=10)$, hoogdynamisch litoraal $(n=10)$, laagdynamisch laag- $(n=1)$, midden- $(n=18)$ en hooglitoraal $(n=5)($ Tabel 1$)$. We hebben gekeken of er ecotopen zijn die het rijkst of armst aan bodemdieren zijn in de huidige situatie.

\subsection{Vergelijking met MWTL}

Om een beeld te krijgen hoe arm of rijk Bath aan bodemdieren is in vergelijking tot het omliggende gebied hebben we naar de soortenrijkdom, totale dichtheden en biomassa's per ecotoop gekeken in vergelijking met data verkregen uit de MWTL-bodemdierenmonitoring. Een vergelijking met de MWTLdata was niet voorzien binnen deze opdracht. We hebben daarom voor deze vergelijking geen recente MWTL-data opgevraagd, maar gebruik gemaakt van een oudere opgewerkte MWTL-dataset uit de periode 2010-2014. De stations van de MWTL monitoring zijn bemonsterd door op korte onderlinge afstand (binnen $0.5 \mathrm{~m}^{2}$ ) tweemaal een steekbuis met een diameter van $10 \mathrm{~cm}$ te steken (totale opp. $0.0156 \mathrm{~m}^{2}$ ) tot de beoogde steekdiepte van $35 \mathrm{~cm}$.

\subsection{Statistiek}

Middels regressieanalyses is gekeken of er een relatie is tussen de biologische indicatoren (soortenrijkdom, dichtheid en biomassa) en droogvalduur. Om te testen of ecotopen rijker of armer zijn aan soortenrijkdom, dichtheid of biomassa is een one-way ANOVA uitgevoerd. Indien er een significant verschil aanwezig was tussen de ecotopen is een post-hoc-Tukey toets uitgevoerd. Dichtheid en biomassa waren niet normaal verdeeld en zijn eerst log-getransformeerd. 


\section{$5 \quad$ Resultaten}

\subsection{Bodemdieren}

\subsubsection{Soortenrijkdom}

Op alle bemonsterde locaties op het slik bij Bath werden bodemdieren aangetroffen in het najaar van 2019. In totaal zijn 36 verschillende taxa gevonden (Tabel 2). Het gemiddelde aantal taxa per station was $7.8 \pm 0.3$ (gemiddelde \pm standaard error), variërend tussen minimaal 2 en maximaal 13 taxa op één locatie. Aan de westzijde van de bestaande strekdam (raai 1, 2 en 3, zie Figuur 4) is geen duidelijk verschil in soortenrijkdom zichtbaar tussen de stations (Figuur 6). Aan de oostzijde van de bestaande strekdam is de soortenrijkdom lager in het laaggelegen deel van de middelste raai (raai 5). De meest voorkomende soort die op het slik bij Bath werd aangetroffen was de rode draadworm Heteromastus filiformis (in 95\% van de stations aangetroffen), gevolgd door de zandpijp Pygospio elegans (75\%), de lijnpissebed Cyathura carinata (68\%), de zeeduizendpoot Hediste diversicolor (66\%), en de brakwaterkorfschelp Potamocorbula amurensis (57\%) (Tabel 2). Laatstgenoemde is een invasieve exoot in de Westerschelde (Kattenwinkel, 2019). Het zelfde geldt voor de Oostzeegroenworm Marenzelleria neglecta (VLIZ Alien Species Consortium, 2011) en de Amerikaanse strandschelp Mulinia lateralis (Craeymeersch et al. 2019), welke aangetroffen werden op 18 en $9 \%$ van de stations, respectievelijk.

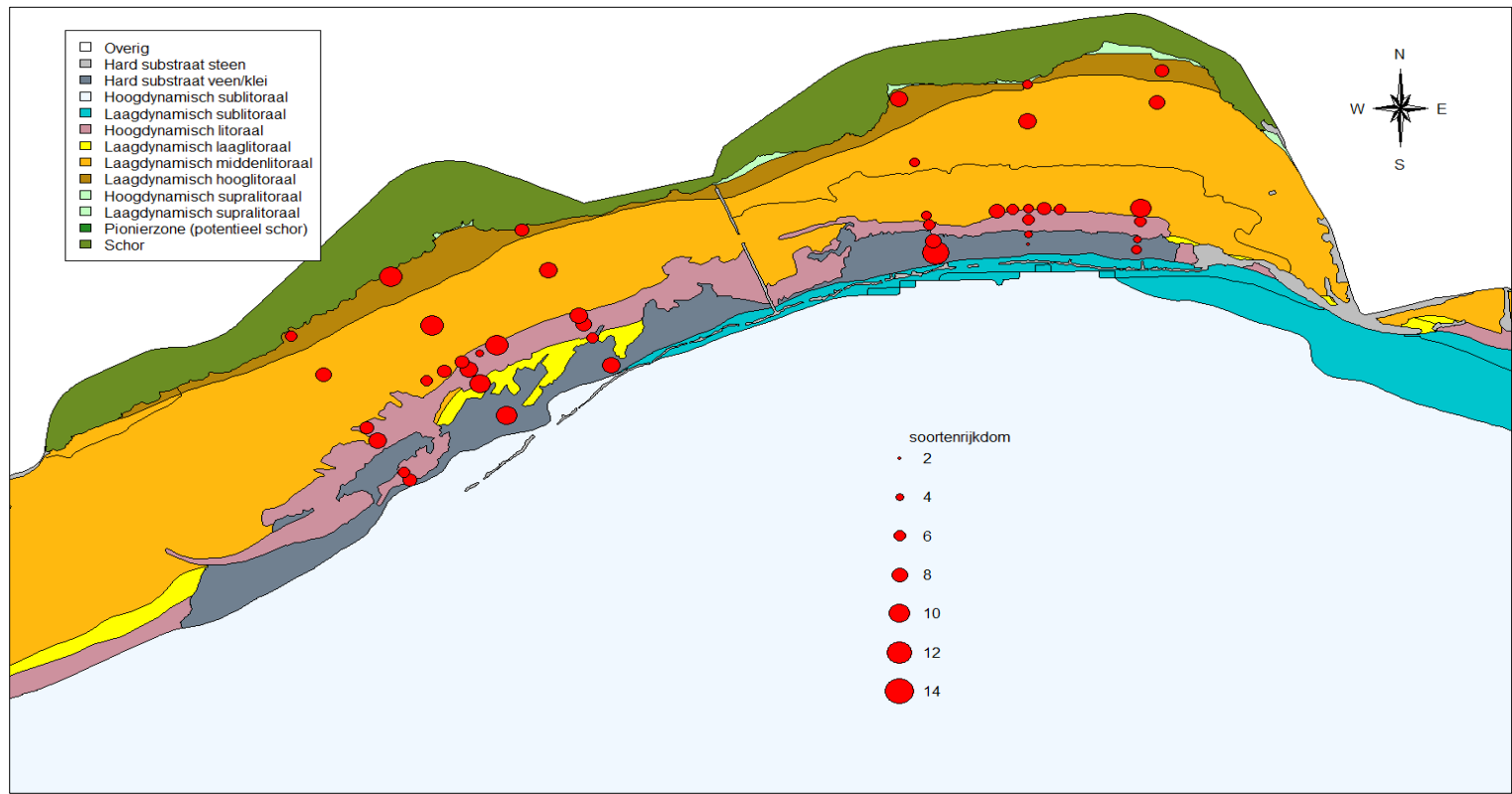

Figuur 6. Soortenrijkdom (aantal soorten) per bemonsteringslocatie. Hoe groter het bolletje hoe meer soorten. Achtergrondkaart: Ecotopenkaart RWS 2016.

\subsubsection{Dichtheid}

Totale dichtheden per locatie verschillen ruimtelijk binnen het gebied (Figuur 7), variërend tussen 84 en 24446 ind. $\mathrm{m}^{-2}$. Aan de westzijde van de bestaande strekdam in het laagdynamisch midden en hoog litoraal werden hogere dichtheden aangetroffen dan in het hoogdynamisch litoraal en op de veen- en kleibanken. Aan de oostzijde van de bestaande strekdam liggen de totale dichtheden een stuk lager in vergelijking tot dichtheden in hetzelfde ecotoop aan de westzijde van de strekdam. De slijkgarnaal Corophium volutator had met gemiddeld $775 \pm 358$ individuen per $\mathrm{m}^{2}$ de hoogste dichtheid in het gebied, gevolgd door $P$. elegans (699 \pm 406 ind. $\left.\mathrm{m}^{-2}\right), C$. carinata $\left(613 \pm 130\right.$ ind. $\mathrm{m}^{-2}$ ) en H. diversicolor $\left(425 \pm 131\right.$ ind $\mathrm{m}^{-2}$ ), zie Tabel 2 . Voor alle soorten die op meer dan twee locaties voorkomen en in dichtheden van meer dan 84 individuen per $\mathrm{m}^{2}$ zijn per soort verspreidingskaarten opgenomen in Bijlage 3. 
Tabel 2. Voorkomen (\% van de 44 stations waar een soort is aangetroffen), dichtheden (aantal individuen per $\mathrm{m}^{2}$ ) en biomassa's ( $\mathrm{g}$ asvrij drooggewicht per $\mathrm{m}^{2}$ ) per aangetroffen taxa op de slikken van Bath. Taxa staan geordend naar hun voorkomen.

\begin{tabular}{|c|c|c|c|}
\hline Soort/Taxa & Voorkomen (\%) & Dichtheid ind. $\mathrm{m}^{-2}$ & Biomassa in $\mathrm{g} \mathrm{m}^{-2}$ \\
\hline Heteromastus filiformis & 95 & $613 \pm 130$ & $0.91 \pm 0.16$ \\
\hline Pygospio elegans & 75 & $699 \pm 406$ & $0.04 \pm 0.02$ \\
\hline Cyathura carinata & 68 & $398 \pm 109$ & $0.11 \pm 0.03$ \\
\hline Hediste diversicolor & 66 & $425 \pm 131$ & $1.47 \pm 0.45$ \\
\hline Potamocorbula amurensis & 57 & $77 \pm 16$ & $1.04 \pm 0.31$ \\
\hline Nereididae & 55 & $159 \pm 37$ & $0.03 \pm 0.01$ \\
\hline Corophium volutator & 50 & $775 \pm 358$ & $0.20 \pm 0.09$ \\
\hline Limecola balthica & 50 & $144 \pm 64$ & $0.83 \pm 0.22$ \\
\hline Scrobicularia plana & 45 & $82 \pm 24$ & $4.88 \pm 1.79$ \\
\hline Alitta succinea & 39 & $70 \pm 23$ & $0.17 \pm 0.06$ \\
\hline Polydora cornuta & 23 & $90 \pm 41$ & $0.01 \pm 0.00$ \\
\hline Marenzelleria neglecta & 18 & $16 \pm 7$ & $0.10 \pm 0.03$ \\
\hline Cerastoderma edule & 16 & $14 \pm 6$ & $0.10 \pm 0.07$ \\
\hline Eteone & 16 & $8 \pm 3$ & $0.00 \pm 0.00$ \\
\hline Hypereteone foliosa & 11 & $9 \pm 4$ & $0.00 \pm 0.00$ \\
\hline Oligochaeta & 11 & $5 \pm 2$ & $0.00 \pm 0.00$ \\
\hline Streblospio benedicti & 11 & $8 \pm 3$ & $0.00 \pm 0.00$ \\
\hline Mulinia lateralis & 9 & $5 \pm 2$ & $0.02 \pm 0.01$ \\
\hline Mya arenaria & 9 & $7 \pm 4$ & $0.00 \pm 0.00$ \\
\hline Crangon crangon & 7 & $6 \pm 4$ & $0.01 \pm 0.01$ \\
\hline Nemertea & 7 & $3 \pm 2$ & $0.00 \pm 0.00$ \\
\hline Peringia ulvae & 7 & $17 \pm 10$ & $0.00 \pm 0.00$ \\
\hline Bivalvia & 5 & $2 \pm 1$ & $0.00 \pm 0.00$ \\
\hline Cirratulidae & 5 & $2 \pm 1$ & $0.00 \pm 0.00$ \\
\hline Microdeutopus & 5 & $3 \pm 2$ & $0.00 \pm 0.00$ \\
\hline Aphelochaeta & 2 & $1 \pm 1$ & $0.00 \pm 0.00$ \\
\hline Arenicola marina & 2 & $1 \pm 1$ & $0.15 \pm 0.15$ \\
\hline Bathyporeia pilosa & 2 & $1 \pm 1$ & $0.00 \pm 0.00$ \\
\hline Capitella & 2 & $2 \pm 2$ & $0.00 \pm 0.00$ \\
\hline Carcinus maenas & 2 & $1 \pm 1$ & $0.01 \pm 0.01$ \\
\hline Caridea & 2 & $1 \pm 1$ & $0.00 \pm 0.00$ \\
\hline Ensis & 2 & $2 \pm 2$ & $0.01 \pm 0.01$ \\
\hline Idotea emarginata & 2 & $1 \pm 1$ & $0.00 \pm 0.00$ \\
\hline Melita palmata & 2 & $1 \pm 1$ & $0.00 \pm 0.00$ \\
\hline Nephtys & 2 & $0 \pm 0$ & $0.00 \pm 0.00$ \\
\hline Petricolaria pholadiformis & 2 & $5 \pm 5$ & $0.00 \pm 0.00$ \\
\hline Totaal & 36 & $3652 \pm 722$ & $10.08 \pm 2.04$ \\
\hline
\end{tabular}




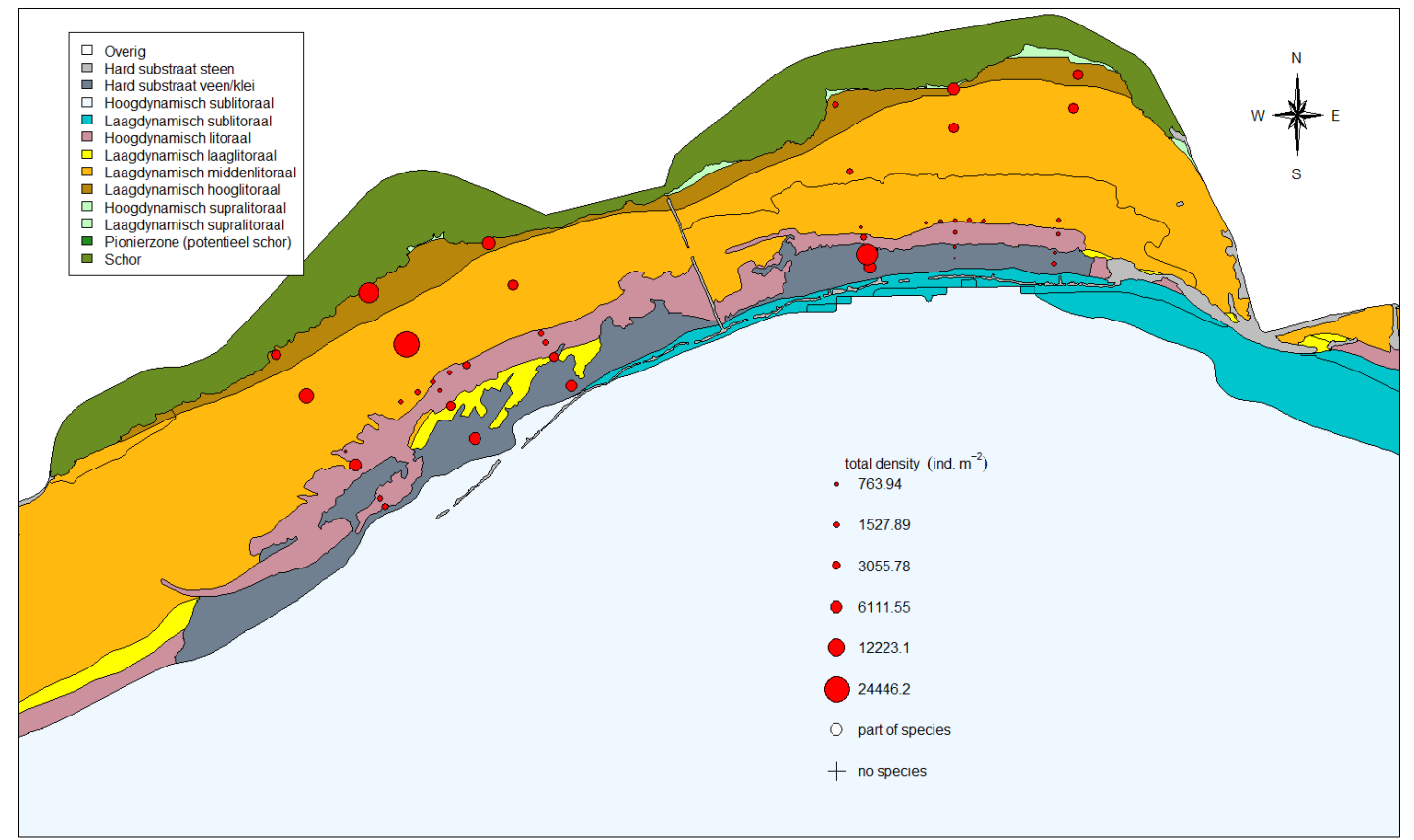

Figuur 7. Totale dichtheid (individuen $\mathrm{m}^{-2}$ ) per bemonsteringslocatie. Hoe groter het bolletje hoe meer individuen per $\mathrm{m}^{2}$. Achtergrondkaart: Ecotopenkaart RWS 2016.

\subsubsection{Biomassa}

Totale biomassa per locatie verschilt ruimtelijk (Figuur 8), variërend tussen 0.01 en $67.57 \mathrm{~g} \mathrm{AFDW} \mathrm{m}^{-2}$. In tegenstelling tot de totale dichtheid is biomassa het hoogst aan de oostzijde van de bestaande strekdam. Biomassa neemt toe richting het schor, waar ook de hoogste dichtheden van de platte slijkgaper Scrobicularia plana en $\mathrm{H}$. diversicolor gevonden worden, zie bijlage 3. S. plana had met een gemiddelde biomassa van $4.88 \pm 1.79 \mathrm{~g}$ AFDW per $\mathrm{m}^{2}$ de hoogste biomassa in het gebied (Tabel 2), gevolgd door de $H$. diversicolor $(1.47 \pm 0.45), P$. amurensis $(1.04 \pm 0.31), H$. filiformis $(0.91 \pm 0.16)$ en het nonnetje Limecola balthica $(0.83 \pm 0.22)$. Voor alle soorten die op meer dan twee locaties voorkomen en in dichtheden van meer dan 84 individuen per $\mathrm{m}^{2}$ zijn voor de biomassa verspreidingskaarten per soort opgenomen in Bijlage 3.

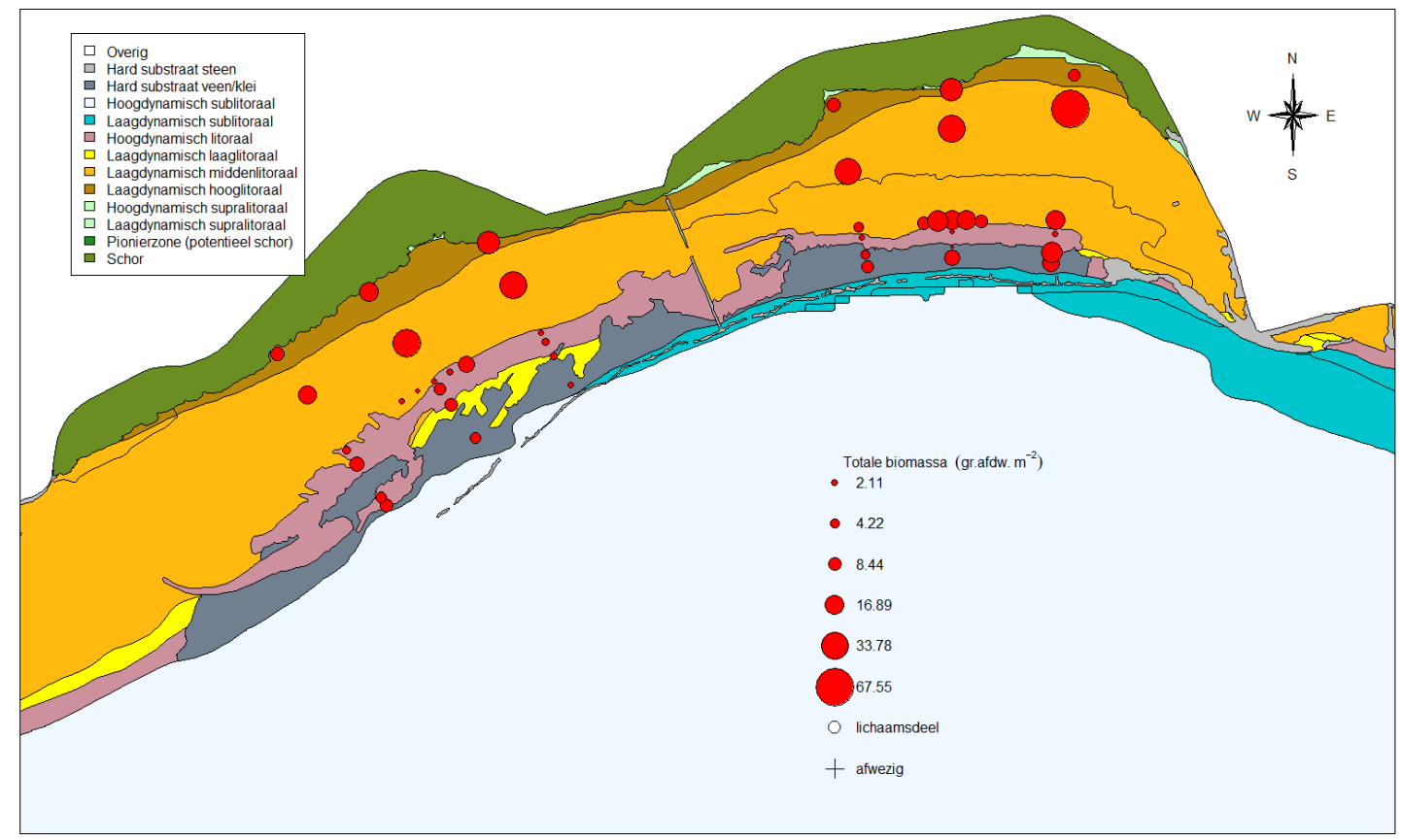

Figuur 8. Totale biomassa ( $\mathrm{g}$ AFDW $\mathrm{m}^{-2}$ ) per bemonsteringsstation. Hoe groter het bolletje hoe meer individuen per $\mathrm{m}^{2}$. Achtergrondkaart: Ecotopenkaart RWS 2016. 


\subsubsection{Schelplengtes}

In totaal komen er acht soorten schelpdieren voor op het slik bij Bath, zijnde $P$. amurensis $(n=76), S$. plana $(n=72)$, L. balthica $(n=141)$, de kokkel Cerastoderma edule $(n=12)$, de Amerikaanse boormossel Petricolaria pholadiformis $(n=5), M$. lateralis $(n=4$; lengtes $1,5,5$ en $9 \mathrm{~mm})$, het mesheft Ensis sp. $(n=2$; lengtes 13 en $17 \mathrm{~mm})$, en de strandgaper Mya arenaria ( $n=3$; lengtes 2, 2 en 3 mm). Figuur 9 toont de lengtes van de vier meest voorkomende schelpdieren. Individuen van $C$. edule werden voornamelijk bij 20 en $40 \%$ droogvalduur (dvd) gevonden en hadden een gemiddelde lengte van $7.1 \pm$ $4.4 \mathrm{~mm}$ (gemiddelde $\pm \mathrm{sd}$ ). Individuen van $L$. balthica hadden een gemiddelde schelplengte van $7.1 \pm$ $2.6 \mathrm{~mm}$. Het is bekend dat jonge nonnetjes in hoge dichtheden voorkomen hoger in de getijdenzone welke ze gebruiken als kinderkamer (Armonies en Hellwig-Armonies, 1992) alvorens ze migreren naar de lager gelegen gebieden in de getijdenzone (Beukema, 1993, Bouma et al. 1998). De meeste nonnetjes bevonden zich in het hoog litoraal ( $80 \% \mathrm{dvd}$ ) waar ze een scheplengte van $6.4 \pm 1.8 \mathrm{~mm}$ hadden, Figuur 10. P. amurensis had een gemiddelde lengte van $9.4 \pm 4.8 \mathrm{~mm}$. P. pholadiformis kwam op één locatie voor (raai $2, \mathrm{dvd} 10 \%$ ) en had een gemiddelde lengte van $1.8 \pm 0.8 \mathrm{~mm}$. S. plana had een gemiddelde lengte van $19.9 \pm 9.0 \mathrm{~mm}$. Hoogste dichtheden werden gevonden bij $70 \%$ droogvalduur, waar ook de individuen het grootste waren (gemiddelde lengte van $21.3 \pm 8.8 \mathrm{~mm}$ ), zie Figuur 10.

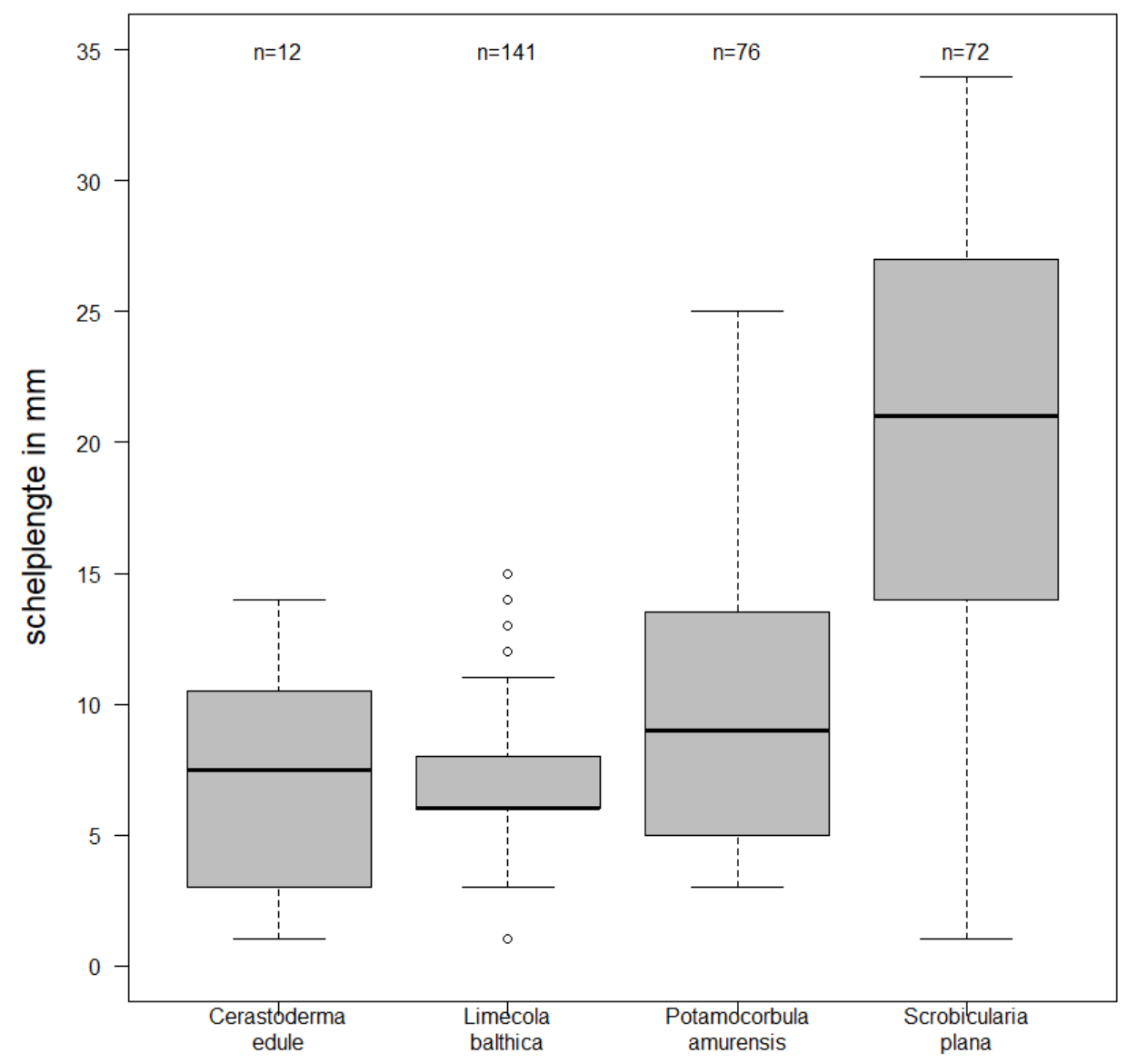

Figuur 9. Schelplengtes (in $\mathrm{mm}$ ) voor de vier meest voorkomende schelpdieren. 

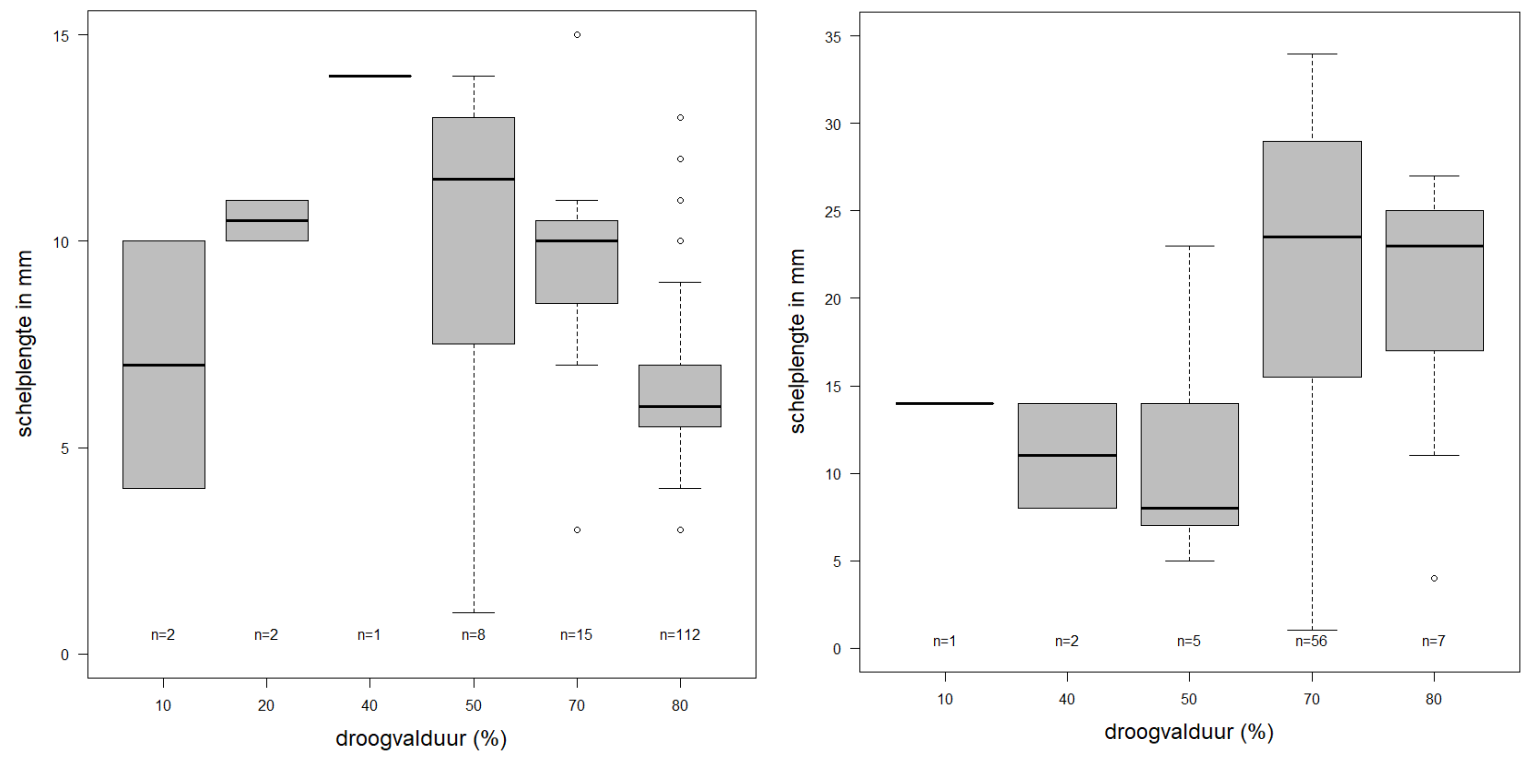

Figuur 10. Schelplengtes (in $\mathrm{mm}$ ) van nonnetjes L. balthica (links) en platte slijkgapers S. plana (rechts) per droogvalduur.

\subsection{Sediment}

Het intergetijdengebied bij Bath bestond voor het merendeel uit fijnzandig slibrijk sediment (Figuur 11). Het gebied had gemiddeld een mediane korrelgrootte van $107.7 \pm 59.6 \mu \mathrm{m}$ en een slibgehalte van 24.0 $\pm 23.4 \%$. Op een aantal locaties was het niet mogelijk een sedimentmonster te nemen door een dikke schelpenlaag (raai 1 , dvd $10 \%$ en $20 \%$ en raai 5 , dvd $40 \%$ ), zie Figuur 12 . Figuur 13 laat de ruimtelijke verdeling van de mediane korrelgrootte (D50) zien over het gebied. De D50 neemt toe van de laagwaterlijn tot 50\% droogvalduur. Daarna neem de D50 af met toenemende droogvalduur (Figuur 14). Hoogste D50 bevind zich op raai 5 (oostelijk van de bestaande strekdam) bij een droogvalduur van $50 \%$. Dit gebied wordt gekenmerkt door grof sediment, zie Bijlage 4 . Het slibpercentage varieerde ruimtelijk binnen het gebied en was het hoogste in het laaggelegen gebied (Figuur 15). Hoogste slibpercentage (89.7\%) werd aangetroffen op raai 2 bij een droogvalduur van $10 \%$.

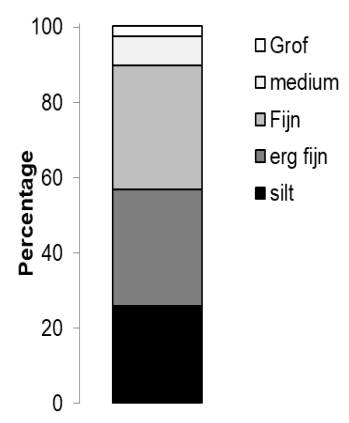

Figuur 11. Verdeling sedimentsamenstelling slikken van Bath. 


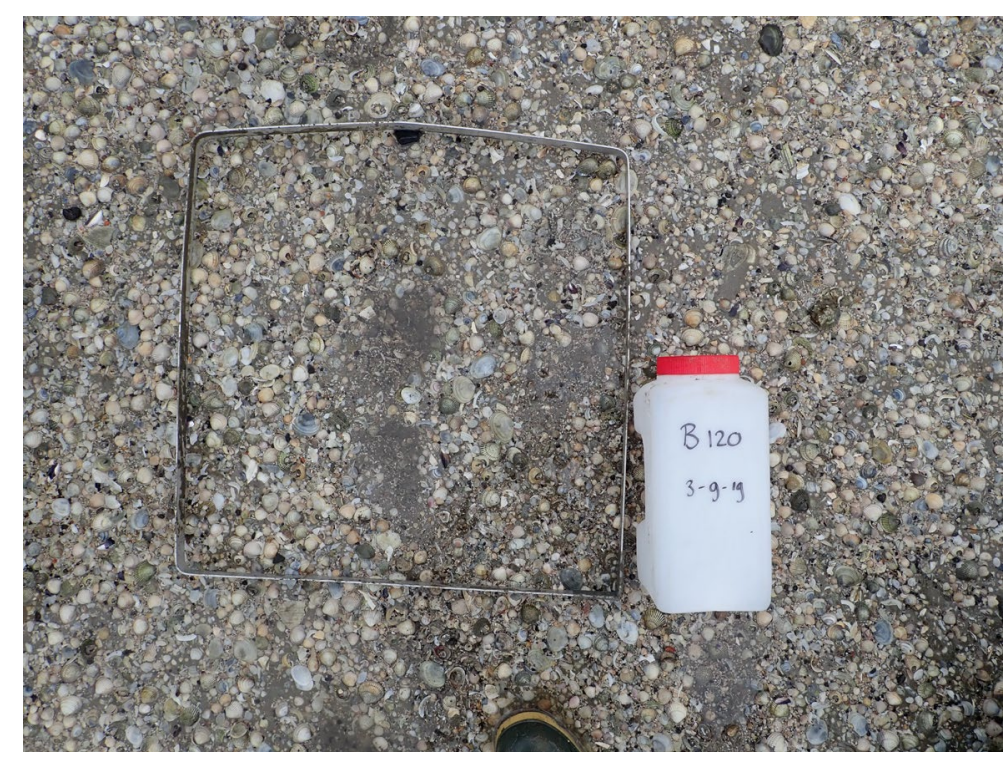

Figuur 12. Dikke schelpenlaag op raai 1 bemonsterstation op $20 \%$ droogvalduur.

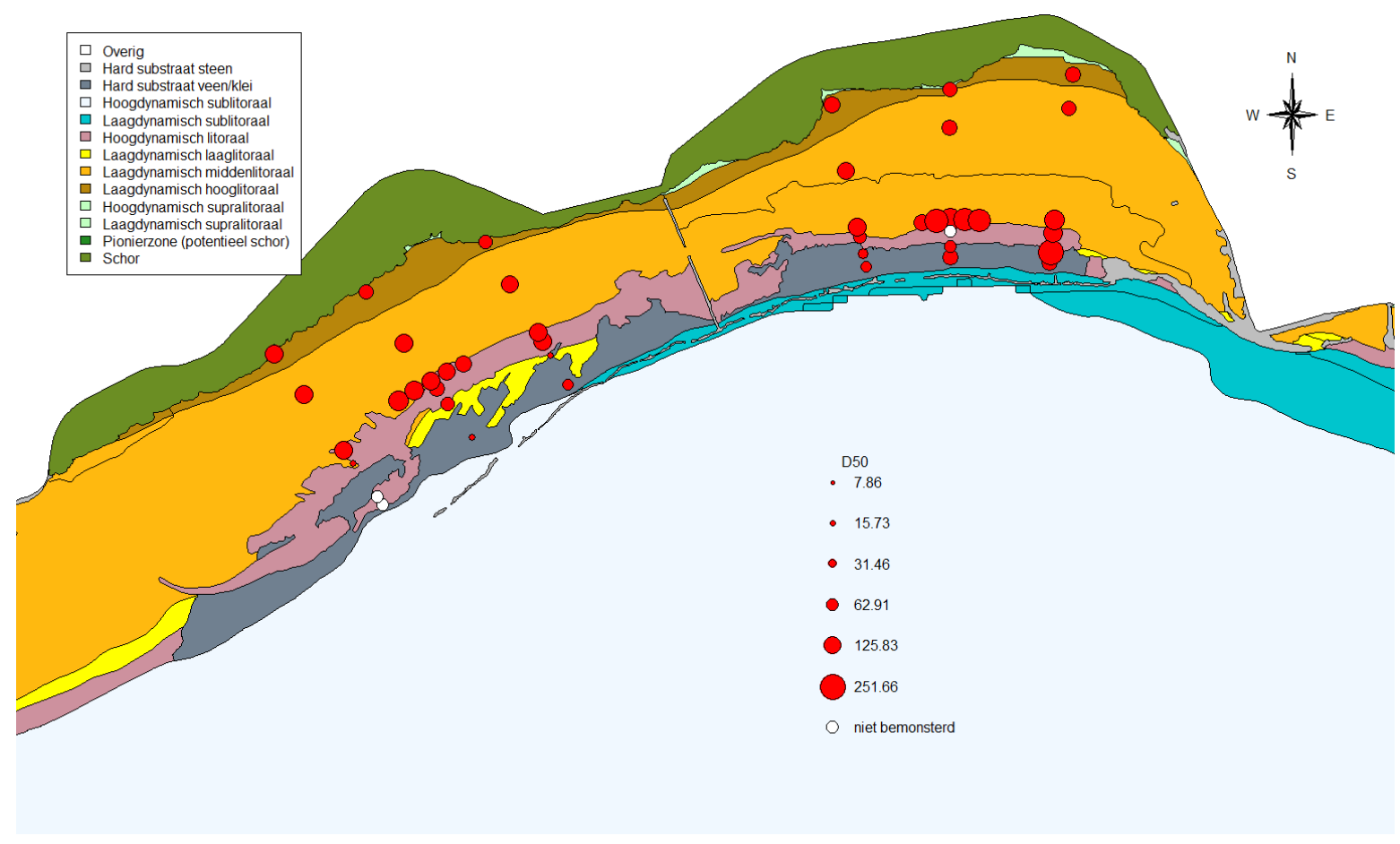

Figuur 13. Mediane korrelgrootte (D50) per bemonsteringslocatie. Hoe groter het bolletje hoe grover het sediment. Achtergrondkaart: Ecotopenkaart RWS 2016. 

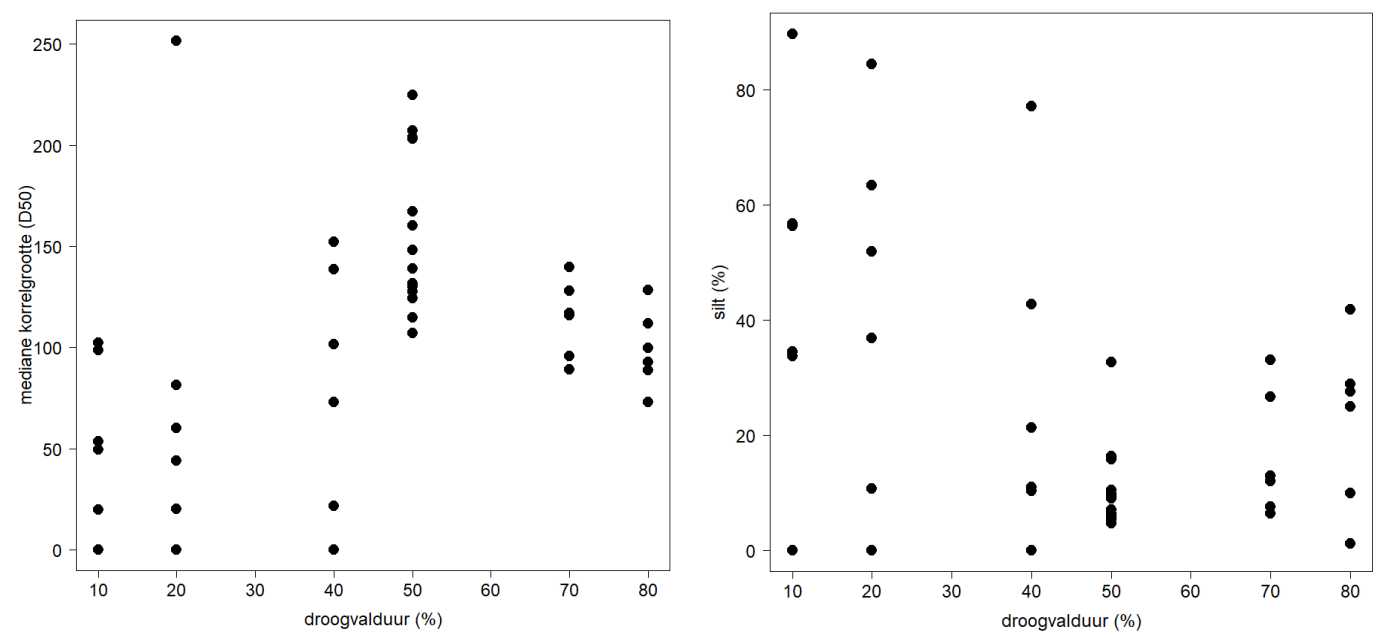

Figuur 14. Mediane korrelgrootte (D50) (links) en percentage slib (rechts) per droogvalduur.

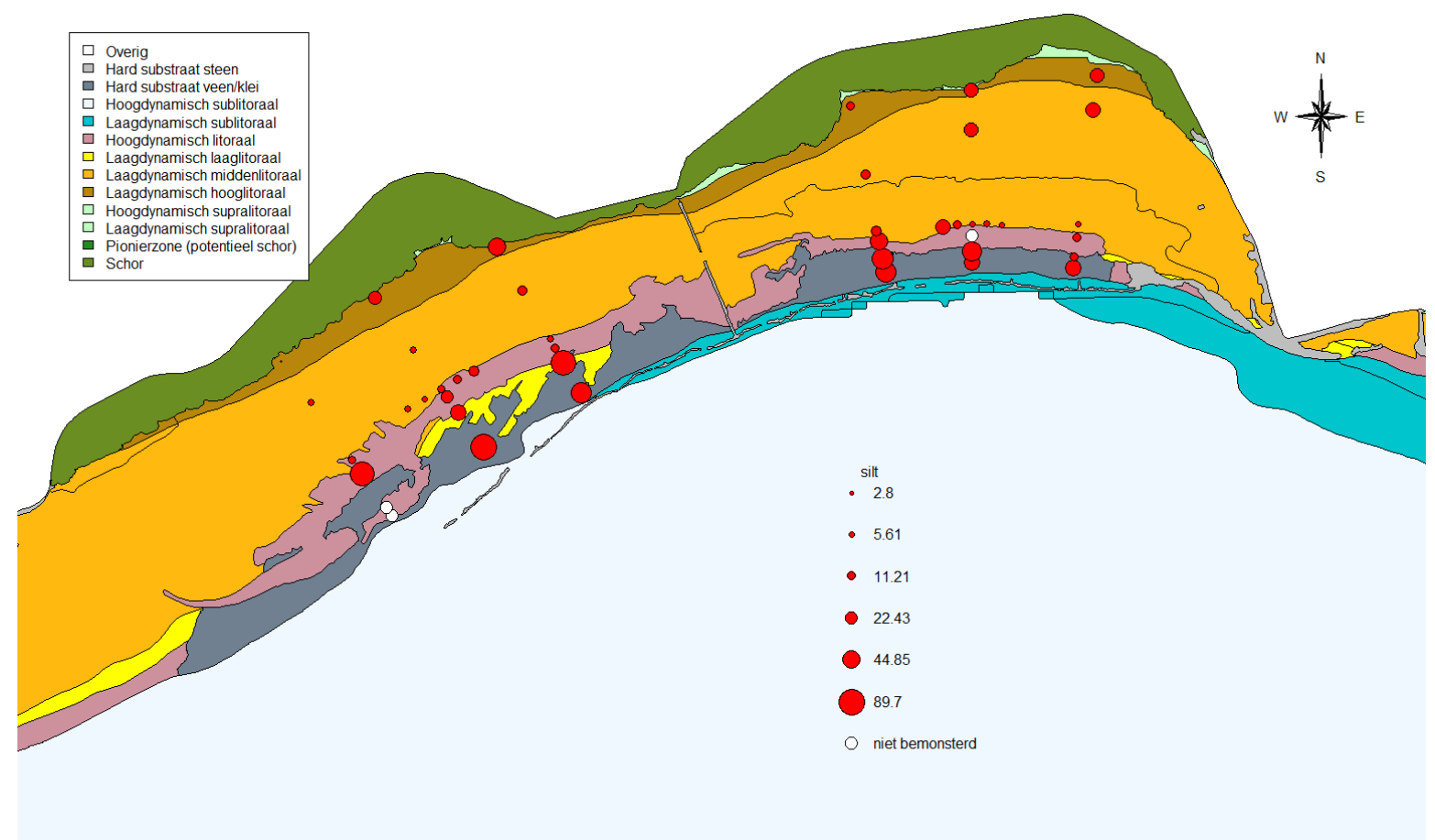

Figuur 15. Slib percentage per bemonsterstation. Hoe groter het bolletje hoe slibrijker. Achtergrondkaart: Ecotopenkaart RWS 2016.

\subsection{Relaties}

\subsubsection{Soortenrijkdom, dichtheid en biomassa in relatie tot sedimentsamenstelling.}

De soortenrijkdom laat geen significante relatie zien met de mediane korrelgrootte $(F(1,42)=0.59, p$ $=0.447)$ en het slibgehalte $(F(1,42)=0.47, p=0.495)$, maar wel met het gehalte aan zeer fijn zand $(F(1,42)=4.39, p=0.042)$ en middel fijn zand $(F(1,42)=5.03, p=0.03)$, Figuur 16 . De totale biomassa laat geen significante relatie zien met de mediane korrelgrootte $(F(1,42)=2.35, p=0.133)$, het slibgehalte $(F(1,42)=0.52, p=0.475)$ en de overige sedimentklassen. De totale dichtheid neemt significant af met een toename in de mediane korrelgrootte $(F(1,42)=6.49, p=0.015)$ en middel fijn zand $(F(1,42)=15.21, p=0.000)$ en neemt significant toe met een toename in slibgehalte $(F(1,42)=$ $5.25, p=0.027)$, Figuur 16 . 

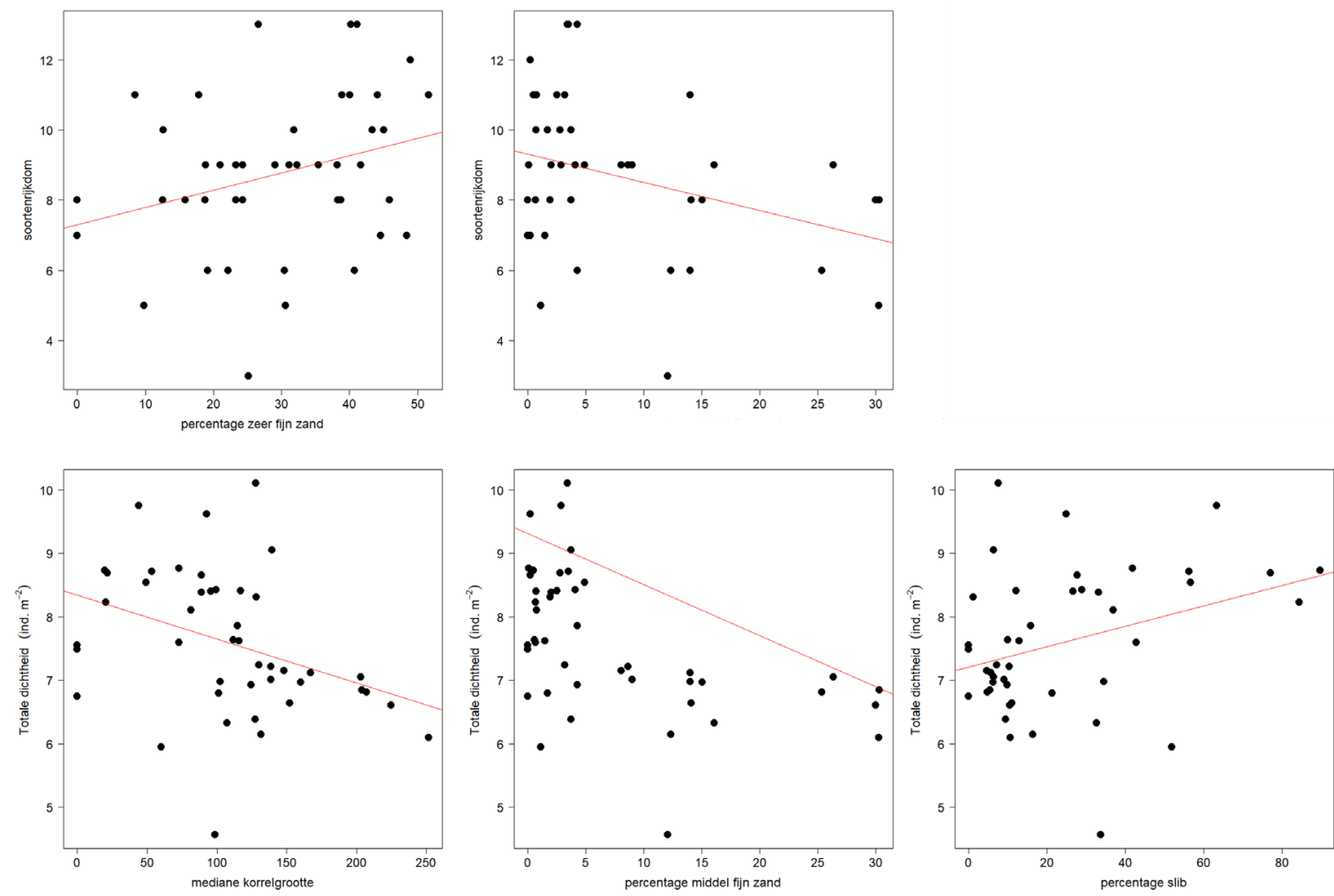

Figuur 16. Significante relaties tussen soortenrijkdom en totale dichtheid (individuen $\mathrm{m}^{-2}$ ) en sedimentsamenstelling.

\subsubsection{Soortenrijkdom, dichtheid en biomassa in relatie tot droogvalduur}

Soortenrijkdom $(F(1,42)=3.56, p=0.066)$, totale dichtheid $(F(1,42)=4.36, p=0.043)$ en totale biomassa $(F(1,42)=8.92, p=0.005)$ per $\mathrm{m}^{2}$ laten een toename zien met droogvalduur. Voor de twee laatst genoemde is deze toename significant, zie Figuur 17.
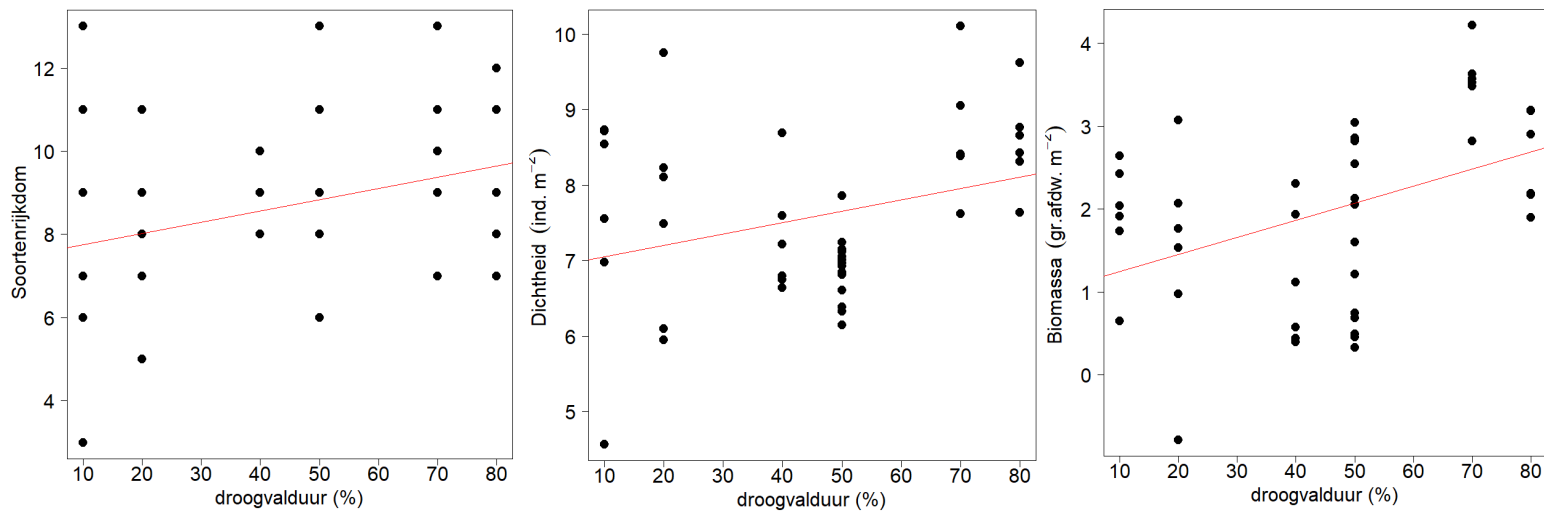

Figuur 17. Relatie tussen soortenrijkdom, totale dichtheid (individuen $\mathrm{m}^{-2}$ ), totale biomassa $\left(\mathrm{g} \mathrm{AFDW} \mathrm{m}^{-2}\right)$ en droogvalduur (in \%).

Van alle voorkomende soorten laten Hediste diversicolor $(F(1,27)=28.29, p=0.000)$, L. balthica $(F(1,20)=4.71, p=0.042)$ en de $S$. plana $(F(1,18)=5.00, p=0.038)$ een significante toename zien met droogvalduur, Figuur 18. Dichtheden van de ambergele zeeduizendpoot Alitta succinea $(F(1,15)=$ 5.23, $p=0.037)$ en de kokerworm Polydora cornuta $(F(1,8)=5.46, p=0.048)$ nemen juist significant af met droogvalduur. $H$. diversicolor $(F(1,27)=24.34, p=0.000)$ laat qua biomassa ook een significante toename zien richting de hoger gelegen delen van het slik, Figuur 19. Ook $H$. filiformis laat een significante $(F(1,40)=6.74, p=0.013)$ toename in biomassa zien richting de hogere delen. Biomassa van $A$. succinea $(F(1,15)=6.99, p=0.018)$ neemt net als hun dichtheid significant toe met 
droogvalduur. Van M. lateralis zijn maar enkele observaties (4 individuen). Deze laten wel een significante $(F(1,2)=111.4, p=0.009)$ toename richting de laagwaterlijn $(\mathrm{dvd}=0 \%)$ zien.

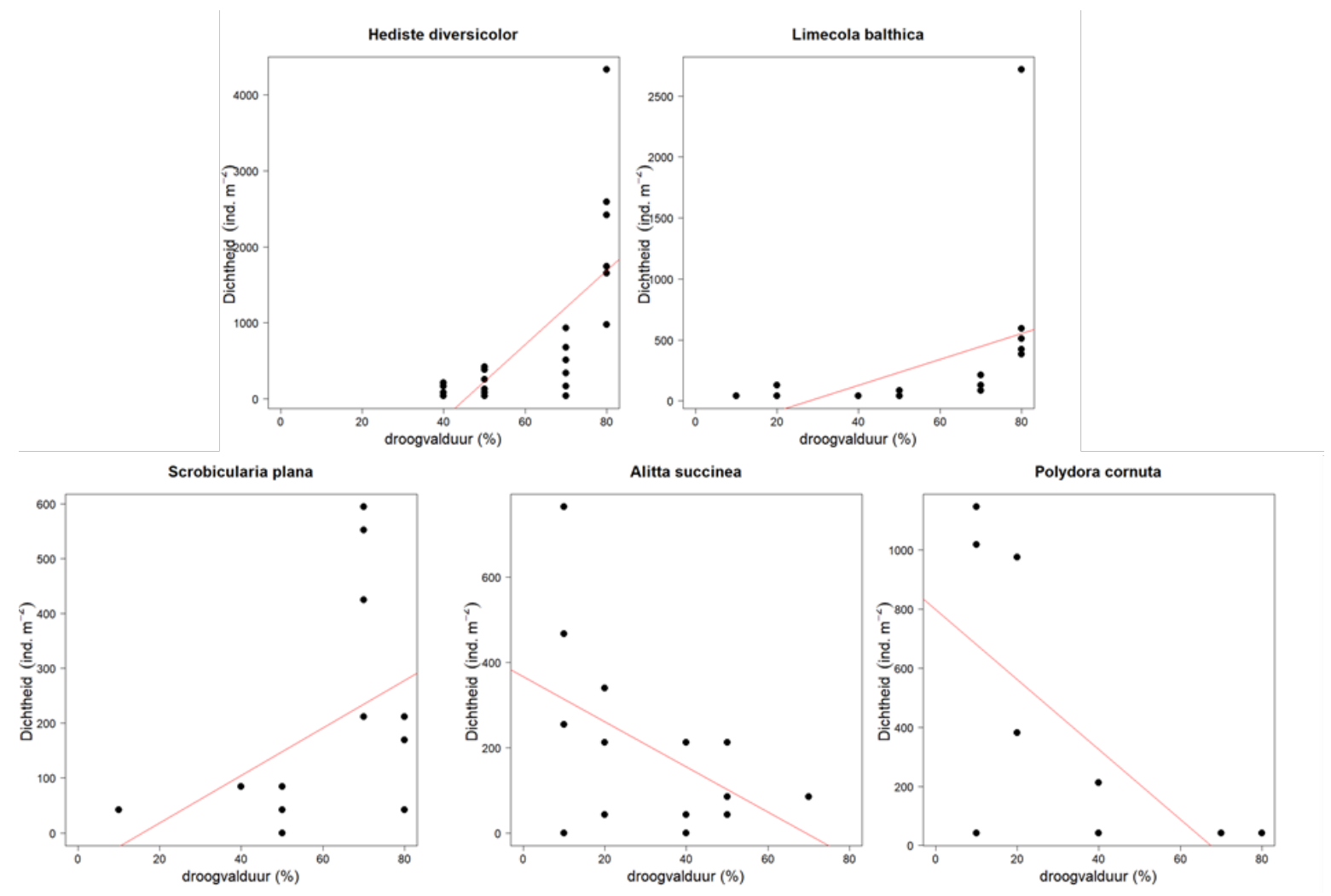

Figuur 18. Significante relaties tussen dichtheid (individuen $\mathrm{m}^{-2}$ ) en droogvalduur (in \%) voor zes soorten bodemdieren.

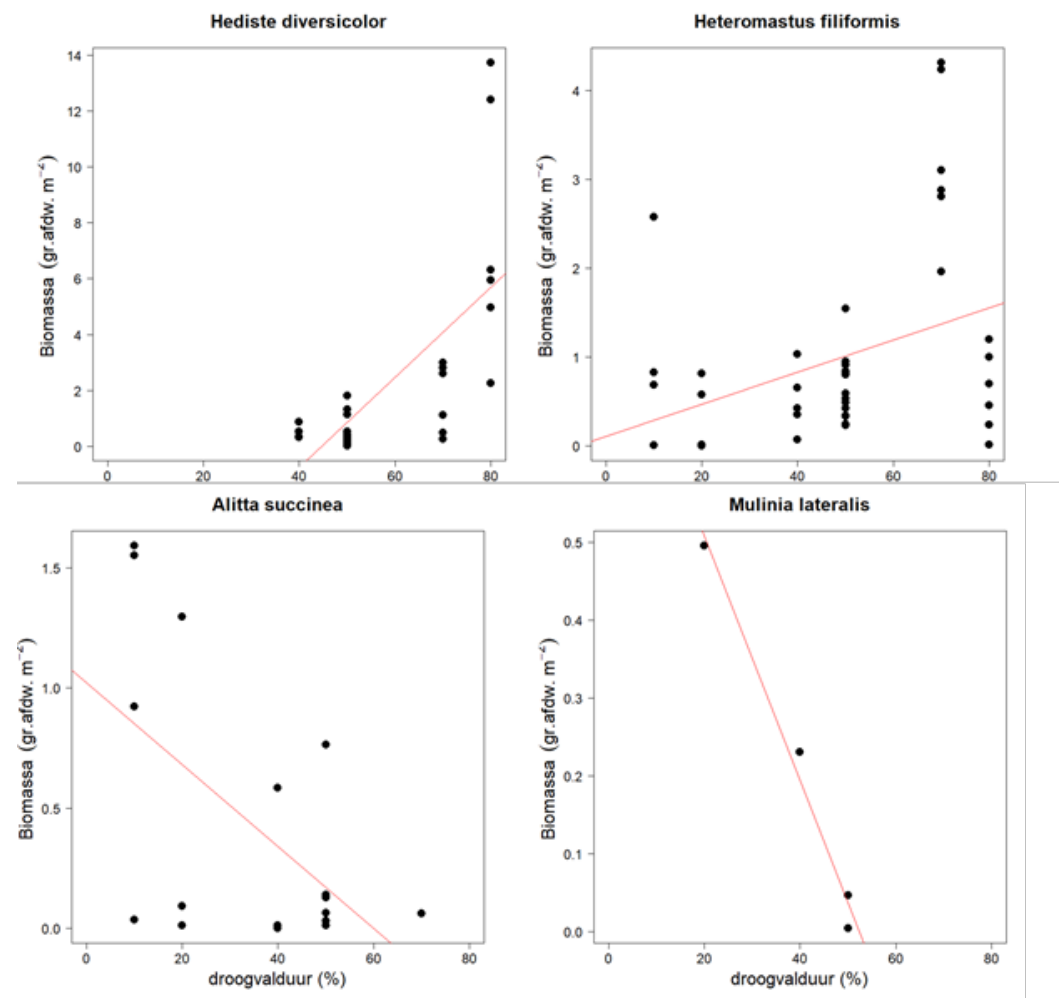

Figuur 19. Significante relaties tussen biomassa ( $g r A F D W m^{-2}$ ) en droogvalduur (in \%) voor vijf soorten bodemdieren. 


\subsubsection{Bodemdieren in relatie tot ecotopen}

We hebben gekeken of er ecotopen zijn die het rijkst of armst aan bodemdieren zijn in de huidige situatie. Soortenrijkdom en dichtheden lijken het hoogst in het laagdynamisch hooglitoraal ecotoop (Figuur 20), echter zijn de verschillen tussen de verschillende ecotopen in termen van soortenrijkdom $(F(3,39)=1.314, p=0.28)$ en dichtheden $(F(3,39)=2.002, p=0.13)$ niet significant. Biomassa was wel significant verschillend tussen de ecotopen $(F(3,39)=4.815, p=0.01)$ met een significant $(p=$ 0.01) hogere biomassa in het laagdynamisch middenlitoraal ecotoop ten opzichte van het hoogdynamische litoraal ecotoop, maar niet ten opzichte van de overige ecotopen.
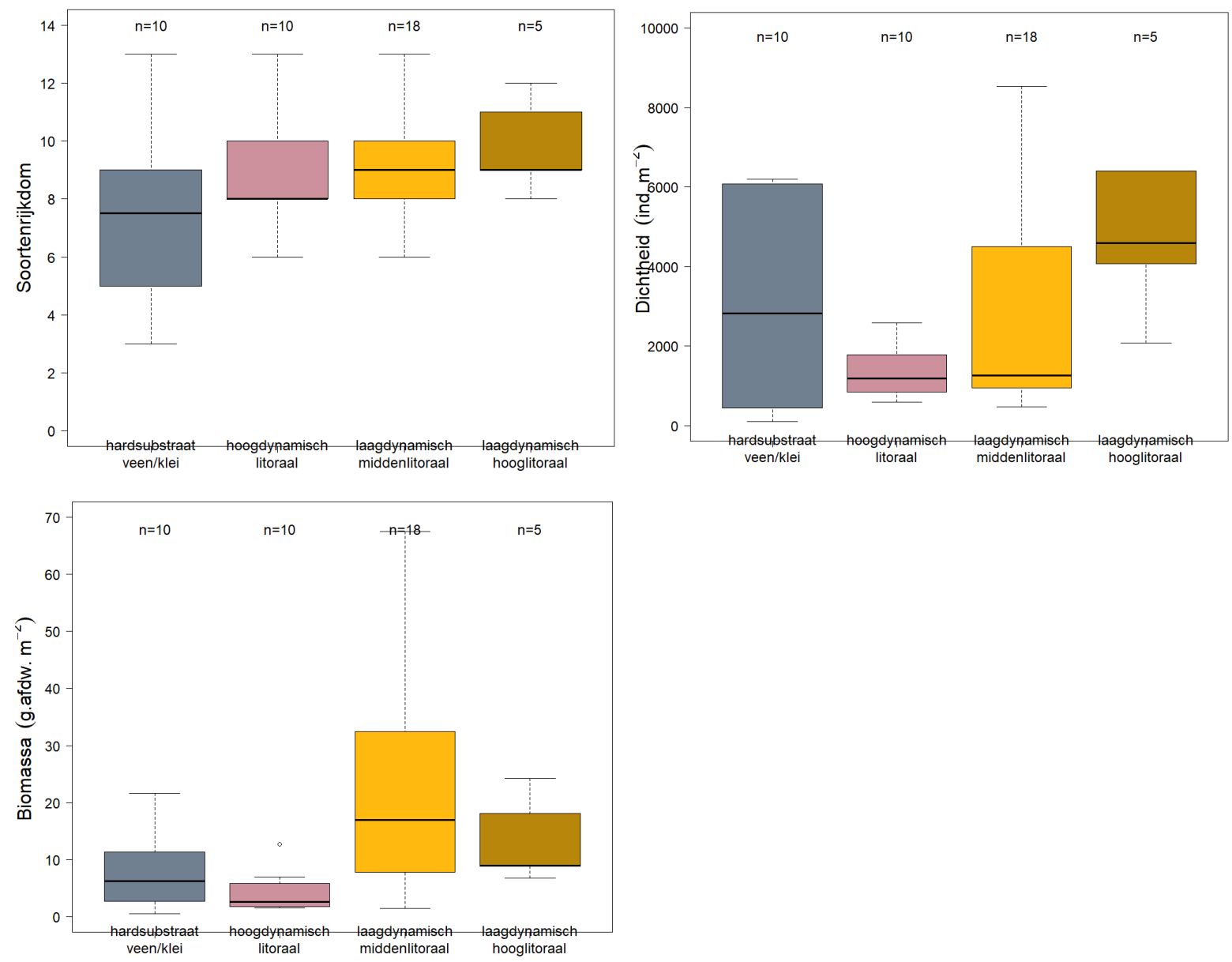

Figuur 20. Soortenrijkdom, dichtheid en biomassa per ecotoop.

\subsection{Vergelijking met MWTL bodemdieren}

Figuur 21 toont voor de relevante ecotopen (hoogdynamisch laaglitoraal, hard substraat veen/klei, laagdynamisch laag-, midden- en hooglitoraal) de bemonsterde stations binnen de MWTL-monitoring die meegenomen zijn in de vergelijking. Op de slikken van Bath hebben we maar 1 station in het laagdynamisch laaglitoraal bemonsterd. Dit ecotoop kunnen we niet vergelijken met de MWTLmonitoring. Andersom missen we voldoende stations binnen het ecotoop hard substraat veen/klei binnen de MWTL-monitoring. Voor de vergelijking kijken we naar boxplots van de parameters per ecotoop maar voeren geen verdere analyses uit. Bij verdere interpretatie moet in acht genomen worden dat de MWTL monitoring een spreiding in jaren ondervangt en een hogere meetdichtheid kent. Daarnaast wordt er een kleiner oppervlak bemonsterd. De gebruikte MWTL dataset omhelst een andere periode dan de bemonstering bij Bath en door grote jaar tot jaar verschillen in bodemdiergemeenschappen zijn de resultaten van Bath niet direct met de MWTL monitoring te vergelijken. De bodemdiergemeenschap bij Bath laat een hogere soortenrijkdom zien in vergelijking tot de gemiddelde soortenrijkdom in het gebied rondom Bath (Figuur 22). Totale dichtheden liggen bij Bath lager dan in het omliggende gebied (Figuur 23). Biomassa binnen het hoogdynamisch litoraal en laagdynamisch hooglitoraal ecotoop lijken vergelijkbaar met het omliggende gebied (Figuur 24). Biomassa binnen het laagdynamisch middenlitoraal ligt een stuk hoger bij Bath dan in het omliggende gebied. 


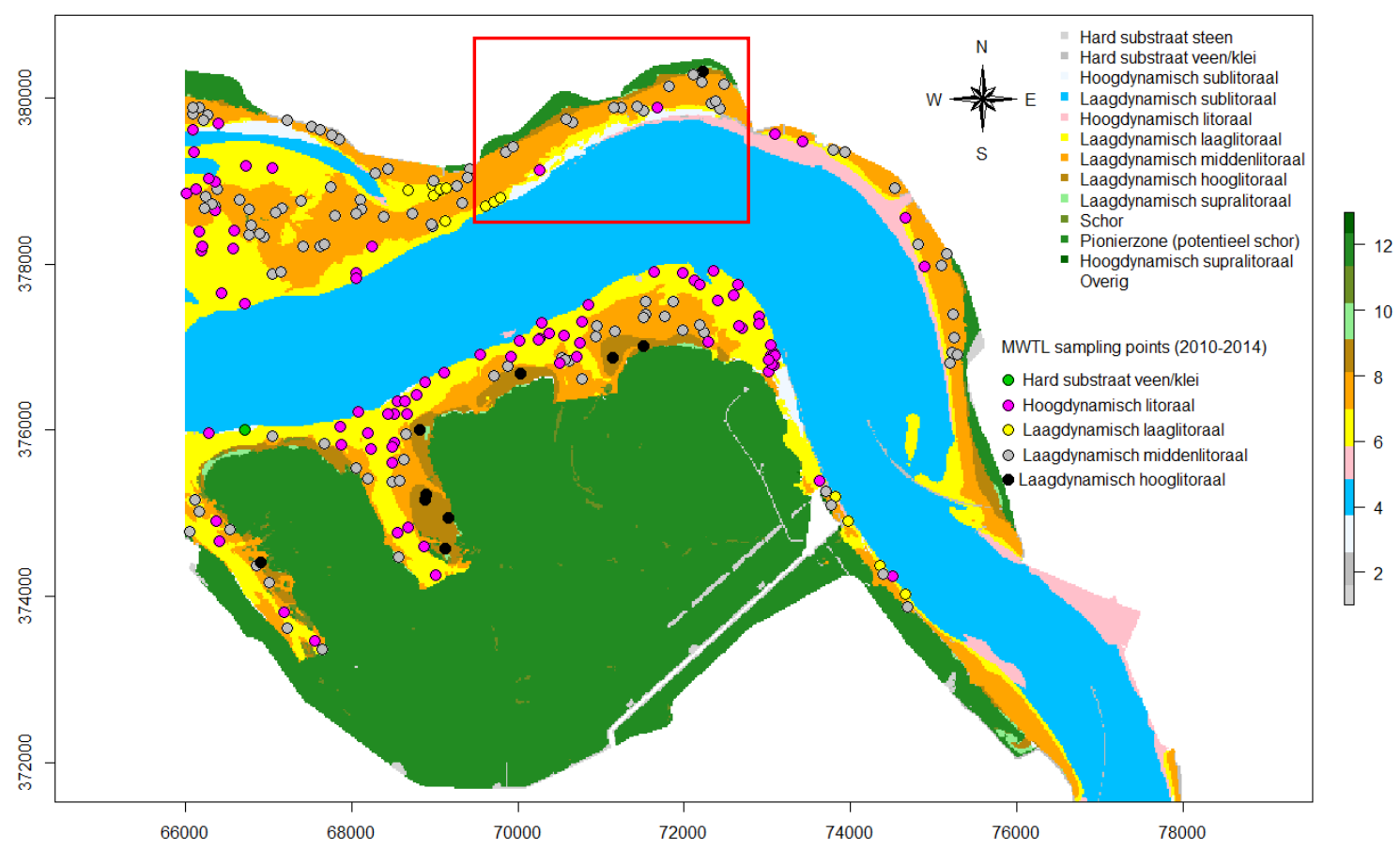

Figuur 21. De bemonsterde stations binnen de MWTL monitoring in de periode 2010 - 2014 voor de ecotopen hoogdynamisch laaglitoraal, hard substraat veen/klei, laagdynamisch laag-, midden- en hooglitoraal welke gebruikt zijn voor een vergelijking met Bath.
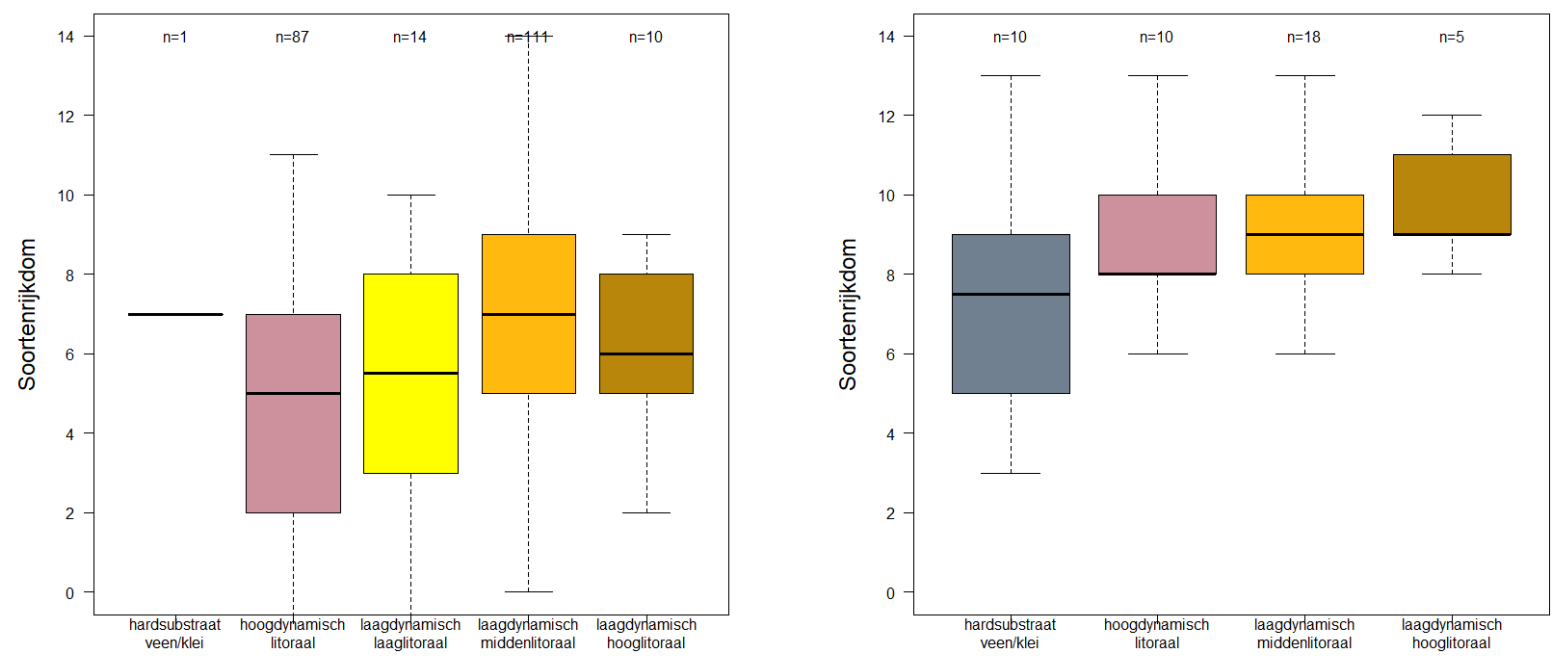

Figuur 22. Links toont de soortenrijkdom per ecotoop op basis van de bemonsterde locaties binnen de MWTL monitoring in de periode 2010-2014, zie Figuur 21. Rechts toont de soortenrijdom verkregen uit de T0 bemonstering in het najaar van 2019 op het slik bij Bath. De éénmalige monitoring bij Bath is niet direct vergelijkbaar met de meerjarige monitoring van de MWTL. 

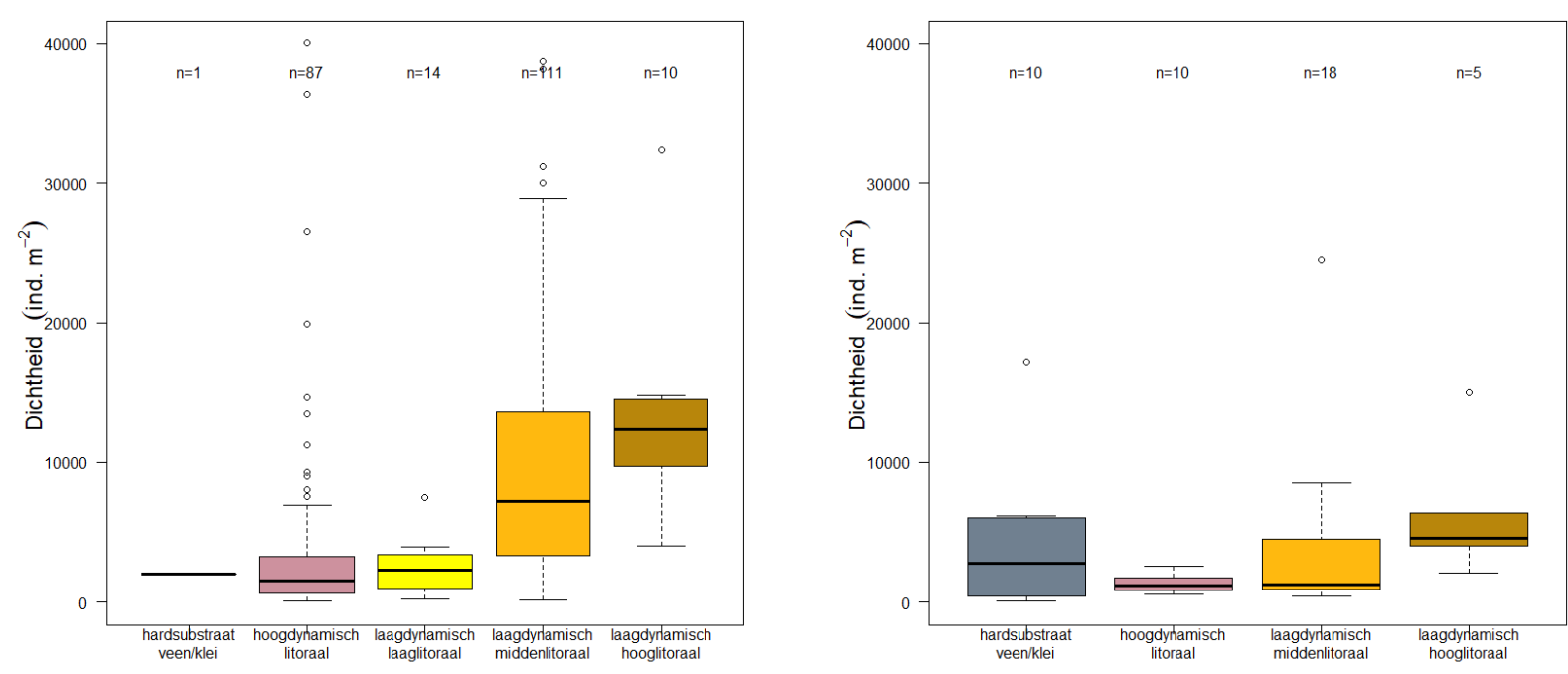

Figuur 23. Links toont de totale dichtheden per ecotoop op basis van de bemonsterde locaties binnen de MWTL monitoring in de periode 2010-2014, zie Figuur 21. Rechts toont de totale dichtheden verkregen uit de TO bemonstering in het najaar van 2019 op het slik bij Bath.
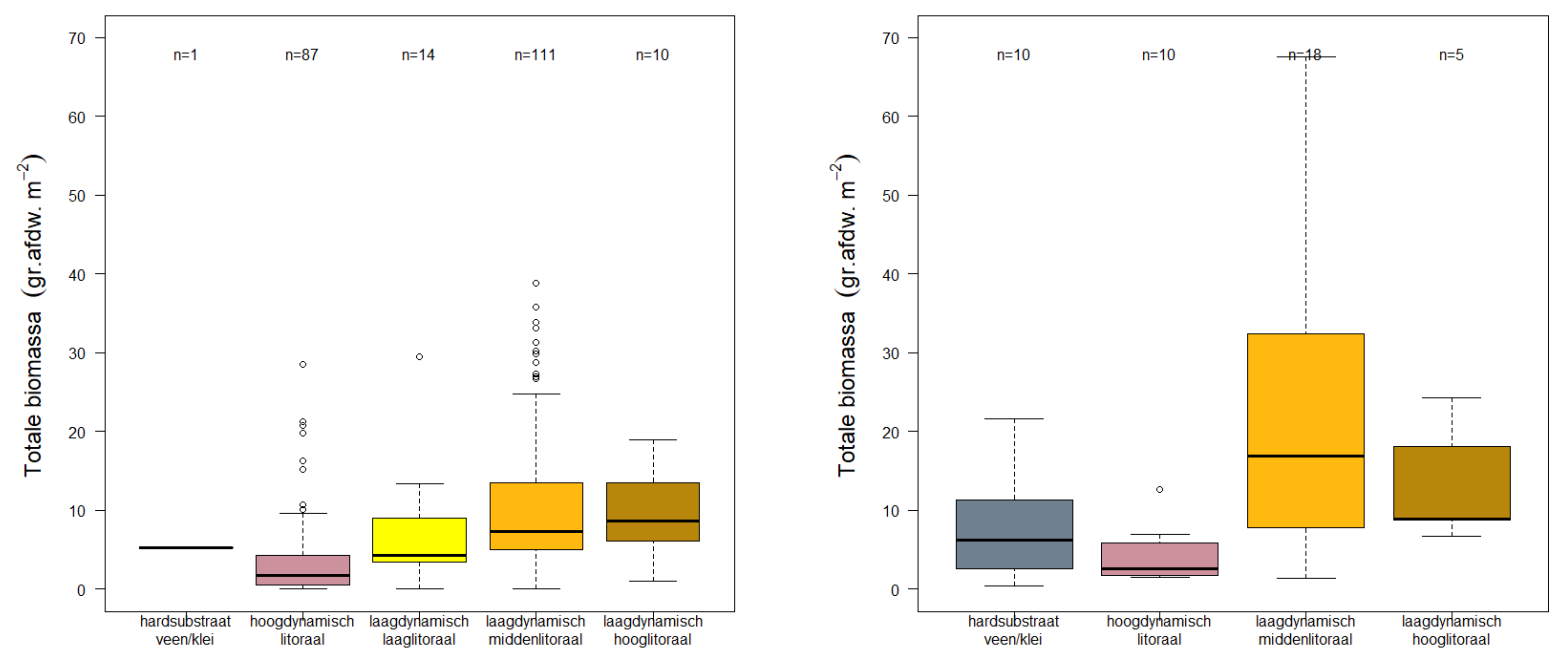

Figuur 24. Links toont de totale biomassa per ecotoop op basis van de bemonsterde locaties binnen de MWTL monitoring in de periode 2010-2014, zie Figuur 21. Rechts toont de totale biomassa verkregen uit de T0 bemonstering in het najaar van 2019 op het slik bij Bath. 


\section{Conclusies en aanbevelingen}

Voorliggende T0-monitoring geeft de huidige toestand van de aanwezige bodemdiergemeenschappen en de sedimentsamenstelling op het slik bij Bath zoals gemonitord op 44 locaties in het najaar van 2019. Het intergetijdengebied bij Bath kan op basis van de ecotopenkaarten uit 2026 en 2018 gekarakteriseerd worden als een grotendeels laagdynamisch slibrijk tot fijnzandig intergetijdengebied met een hoogdynamische zone met bloot spoelende klei en veenbanken in de buurt van de laagwaterlijn. Het gebied met klei en veenbanken is tussen 2016 en 2018 duidelijk toegenomen. In totaal werden 36 verschillende bodemdiertaxa aangetroffen in het najaar van 2019. De soortenrijkdom is met gemiddeld $7.8 \pm 0.3$ taxa per bemonsterd station relatief hoog in 2019. Benadrukt moet worden dat het hier gaat om een momentopname (najaar 2019) en dat jaar-op-jaar variaties in het voorkomen, dichtheden en biomassa's van bodemdieren groot kunnen zijn. Zo zijn in het verleden hoge dichtheden van het vlokreeftje Melita palmata gevonden op de slikken bij Bath (Figuur 25), terwijl in de T0-monitoring slechts 1 individu werd aangetroffen. Hetzelfde geldt voor de slijkgarnaal Corophium volutator welke tijdens een veldinventarisatie in 2016 (Ysebaert en Brummelhuis, 2016) tot één van de dominante soorten in het gebied gerekend kon worden, evenals tussen 2010 en 2014 binnen de MWTL-monitoring (Figuur 26).

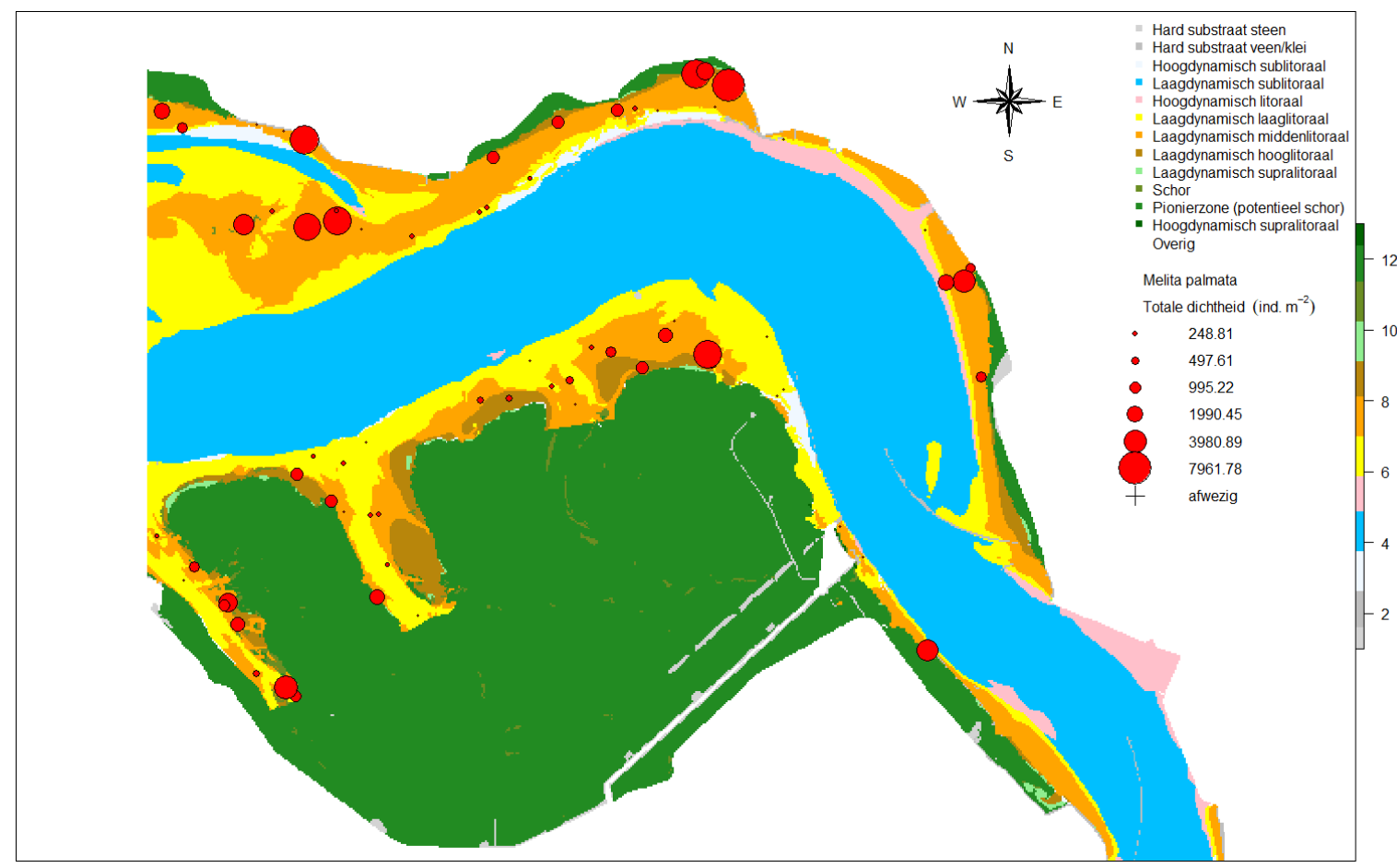

Figuur 25. Verspreidingskaart van het vlokreeftje Melita palmata tussen 2010 en 2014 (MWTL data). Hoe groter het bolletje hoe meer individuen per $\mathrm{m}^{2}$. Achtergrondkaart: Ecotopenkaart RWS 2016. 


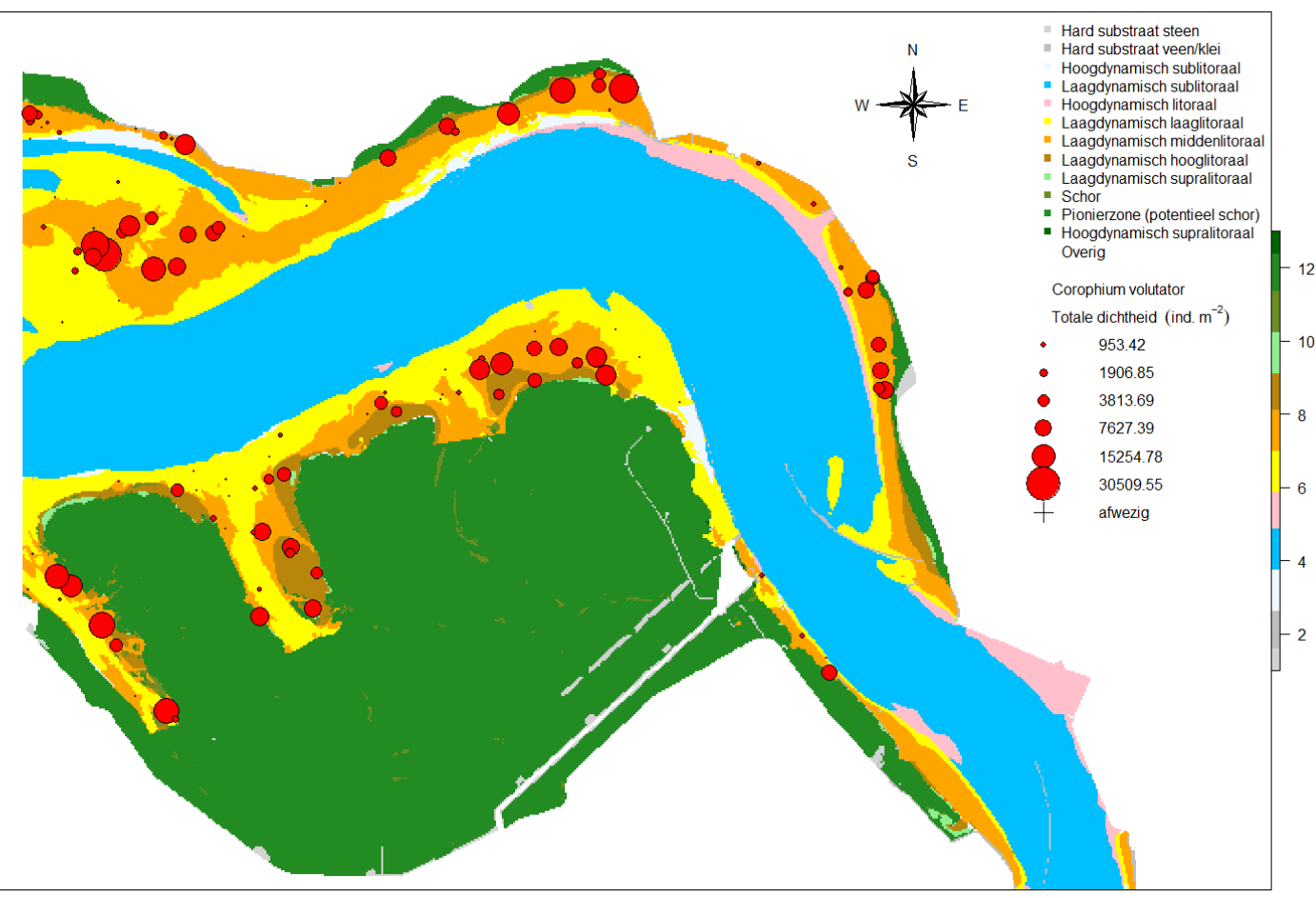

Figuur 26. Verspreidingskaart van de slijkgarnaal Corophium volutator tussen 2010 en 2014 (MWTL data). Hoe groter het bolletje hoe meer individuen per $\mathrm{m}^{2}$. Achtergrondkaart: Ecotopenkaart RWS 2016.

Uit de veld inventarisatie van Ysebaert en Brummelhuis (2016) bleek verder dat het voorkomen van bodemleven op de klei- en veenbanken en het hoogdynamisch slik beperkt was tot enkele soorten in lage aantallen (Figuur 27). Naar de dijk toe nam het aantal soorten, dichtheden en biomassa toe met de hoogste waarden in de slibrijke laagdynamische zone. Een dergelijke toename is ook aanwezig in de stations bemonsterd binnen de MWTL-monitoring en is ook in de huidige bemonstering vastgesteld. Op het slik van Bath laten de zeeduizendpoot $H$. diversicolor, het nonnetje $L$. balthica en de platte slijkgaper S. plana een significante toename in dichtheden met droogvalduur zien. Biomassa is het hoogst in het laagdynamisch middenlitoraal. S. plana, H. diversicolor, de brakwaterkorfschelp P. amurensis, de draadworm $H$. filiformis en $L$. balthica vertegenwoordigden het grootste aandeel aan biomassa. Er is geen significant verschil in soortenrijkdom en dichtheden tussen de verschillende ecotopen. Biomassa is wel significant hoger in het laagdynamisch middenlitoraal t.o.v het hoogdynamische litoraal. Totale dichtheid neemt toe naar mate het sediment slibrijker wordt. Biomassa laat geen relatie zien met sedimentsamenstelling.

Het intergetijdengebied bij Bath is aangewezen als een gebied waar strekdammen kunnen leiden tot een verhoging van de ecologische waarde van het gebied. Volgens het Monitoringsplan Buitendijkse Maatregelen bij Bath (Provincie Zeeland) wordt de huidige toestand van het slik bij Bath beoordeeld als een gebied met een relatief lage ecologische waarde als gevolg van de hoge hydrodynamiek en de aanwezigheid van steeds verder bloot-spoelende soortenarme kale klei- en veenbanken. Toch komen er in deze klei- en veenbanken verschillende soorten bodemdieren voor, en waren er geen significante verschillen in soortenrijkdom, dichtheid en biomassa in het hardsubstraat (klei- en veenbanken) ten opzichte van de andere aanwezige ecotopen binnen het gebied. Ondanks dat er veel soorten voorkwamen waren de dichtheden en biomassa's relatief laag in dit gebied. 


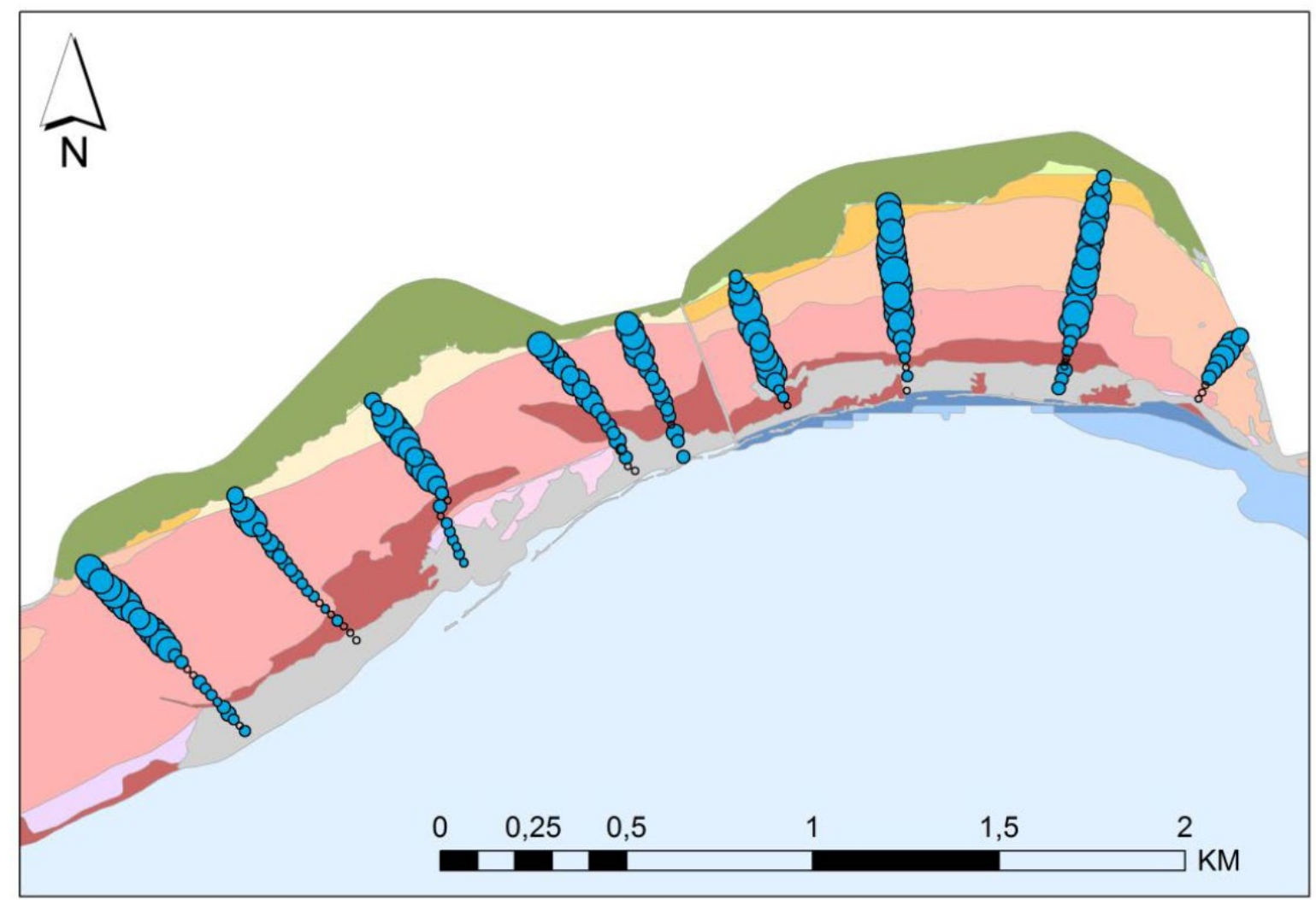

Figuur 27. Soortenrijkdom op basis van Ysebaert \& Brummelhuis 2016. Hoe groter het bolletje hoe meer soorten. Achtergrondkaart: Ecotopenkaart RWS. Overgenomen uit Jaspers et al. 2018.

Tijdens de T0-monitoring zijn drie exoten gevonden: twee bivalven, de brakwaterkorfschelp $P$. amurensis en de Amerikaanse strandschelp en M. lateralis, en de Oostzeegroenworm M. neglecta. Deze kwamen met name voor in het gebied tussen de toekomstige strekdammen (gebied met een droogvalduur van $50 \%$ of minder). $P$. amurensis werd aangetroffen in de klei- en veenbanken (Figuur 27) en op schelpenbanken.

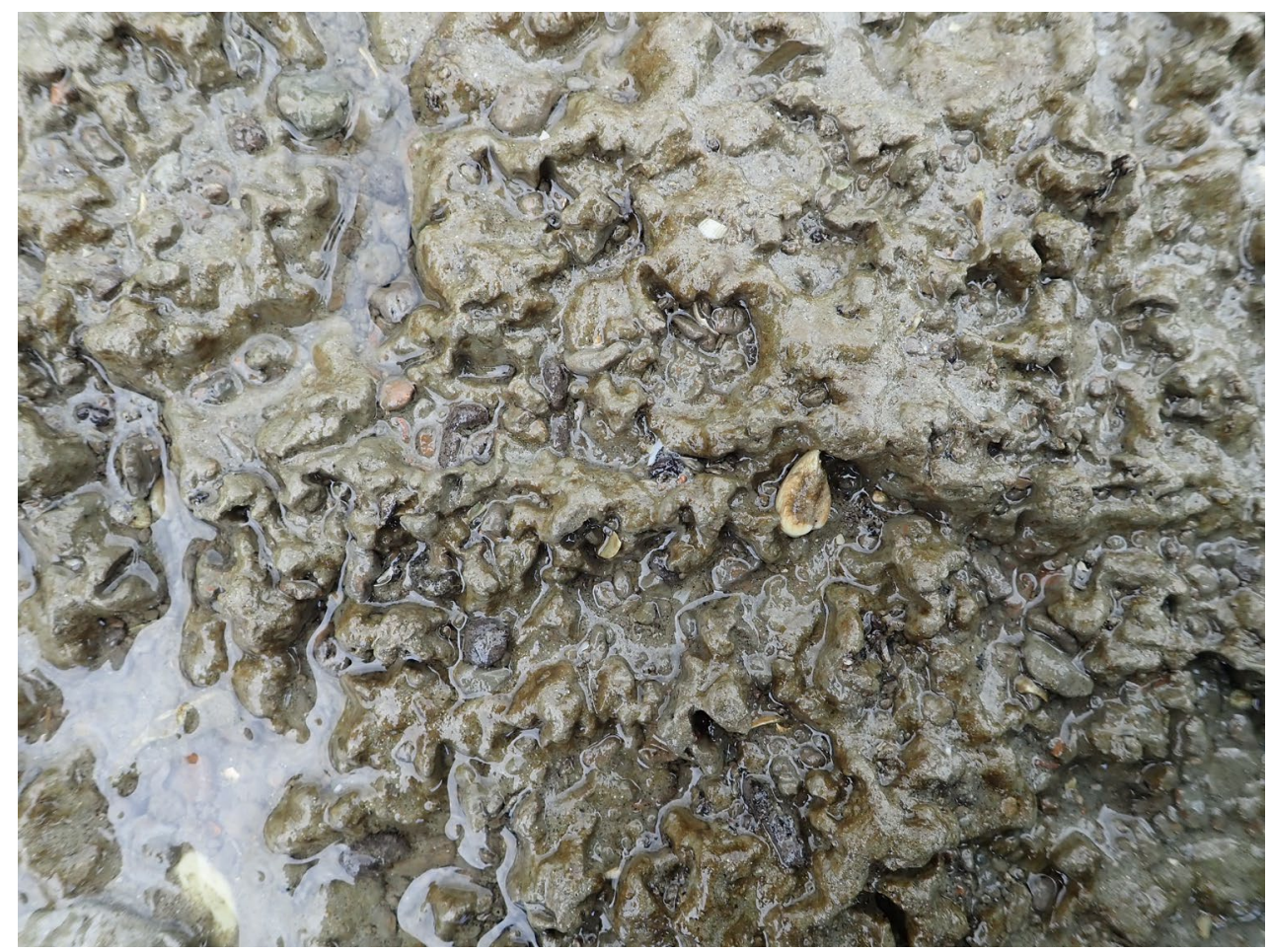

Figuur 28. $P$. amurensis in een kleibank op het slik van Bath ( 3 september 2019). 


\subsection{Aanbevelingen vervolgmonitoring}

In tegenstelling tot parameters zoals sediment hoogte, sediment samenstelling en vogels welke jaarlijks gemonitord zullen worden na aanleg van de strekdammen staat een bodemdierbemonstering alleen gepland voor T1 en T5, 1 jaar (2021) en 5 jaar (2026) na aanleg. Door eens per vijf jaar de bodemdieren te bemonsteren in combinatie met grote jaar-op-jaar variatie verkrijg je geen inzicht in de ontwikkeling in de tijd van de bodemdiergemeenschappen als voedsel voor vogels. Ons advies is om minstens één extra bemonster jaar toe te voegen om inzicht te verkrijgen in deze ontwikkeling. De geplande T1 en T5, 1 jaar (2021) en 5 jaar (2026) na aanleg van de strekdammen, kan met enkele kleine aanpassingen op eenzelfde manier uitgevoerd worden als de T0. De T0-monitoring geeft een goed beeld van de ruimtelijke spreiding van soorten en sedimentsamenstelling binnen het gebied.

Op de 50\% droogvalduur zijn meerdere stations loodrecht op raai 2 en raai 4 bemonsterd. Deze stations lieten in de huidige situatie weinig variatie in bodemdieren zien (zie Bijlage 3). Indien grote verschillen in bodemdiersamenstelling op verschillende afstanden tot de strekdam (op basis van de extra punten loodrecht op de raai) worden vastgesteld bij de T1 en T5 monitoring, kan besloten worden om, in samenspraak met de opdrachtgever, hier extra aandacht aan te geven.

De locaties van de bemonsteringspunten langs de raaien zijn op basis van de droogvalduur bepaald. Dit kan van jaar tot jaar verschillen door morfologische veranderingen, mede door de aanleg van de strekdammen. M.a.w., de bemonsteringspunten zullen bij de T1 en T5 niet op dezelfde locatie liggen als bij de T0, maar wel eenzelfde droogvalduur hebben. Het bepalen van de bemonsterpunten langs de raai middels droogvalduur heeft de voorkeur over stationaire punten, omdat de kans bestaat bij stationaire punten dat een gradiënt in droogvalduur verloren gaat wanneer het gebied morfologisch verandert. De punten tussen de strekdammen kunnen bijvoorbeeld tijdens de nul-situatie verschillen in droogvalduur, maar door sedimentatie allemaal op dezelfde hoogte komen te liggen. Wanneer dit gebeurd wordt de parameter droogvalduur niet meer goed ondervangen. Afhankelijk van de ontwikkeling tussen de strekdammen en op basis van een visuele inspectie kan besloten worden om extra bemonsteringslocaties toe te voegen.

Wij adviseren om in een vervolgmonitoring de stations gelegen op de $10 \%$ en $20 \%$ droogvalduur niet te voet te bemonsteren, maar vanuit een boot, mits haalbaar. Op de $10 \%$ en $20 \%$ droogvalduur bevinden zich oude afgravingen die soms meer dan $50 \mathrm{~cm}$ diep zijn (Figuur 29). Wanneer deze geulen opslibben is het een verraderlijk gebied om te voet te betreden. 


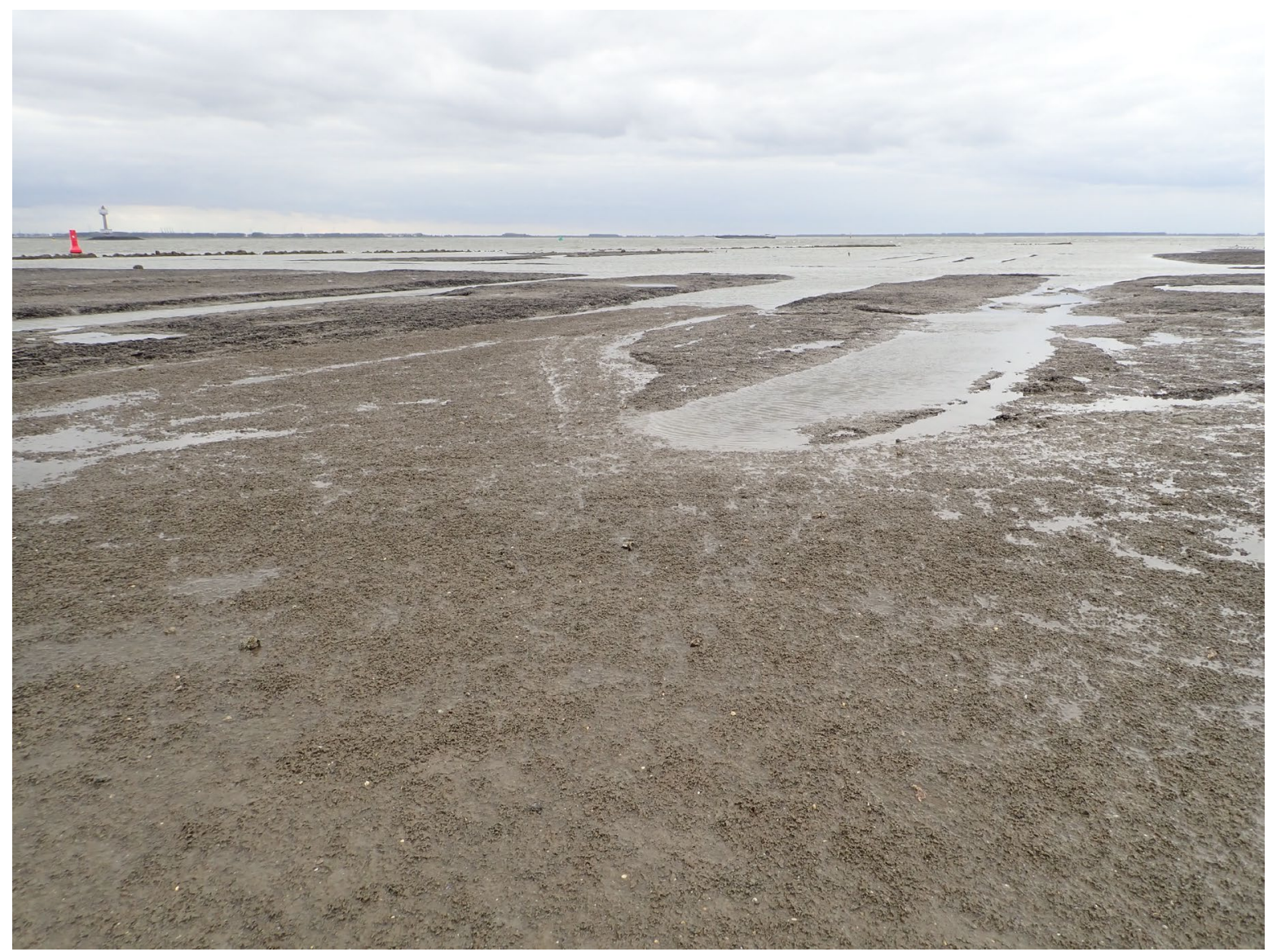

Figuur 29. Afgravingen nabij de waterlijn.

Tot slot is het belangrijk de biologische monitoring (zowel bodemdieren maar indien mogelijk ook het gebruik van het gebied door vogels) te koppelen aan een gedegen morfologische (sedimentatie/erosie, sedimentsamenstelling) en hydrologische (stroming, golven) monitoring, incl. modellering. Het monitoringsplan voor de buitendijkse maatregelen bij Baalhoek en Knuitershoek kan hiervoor als leidraad dienen. 


\section{Kwaliteitsborging}

Wageningen Marine Research beschikt over een ISO 9001:2015 gecertificeerd

kwaliteitsmanagementsysteem. Dit certificaat is geldig tot 15 december 2021. De organisatie is gecertificeerd sinds 27 februari 2001. De certificering is uitgevoerd door DNV GL. 


\section{Literatuur}

Armonies, W., \& M. Hellwig-Armonies (1992). Passive settlement of Macoma balthica spat on tidal flats of the Wadden Sea and subsequent migration of juveniles. Netherlands Journal of Sea Research, 29 (4): $371-378$.

Barneveld, H.J., R.P. Nicolai, T.J. Boudewijn, I. Van de Moortel, R. Postma (2018). Evaluatie Scheldeestuarium: de toestand van Veiligheid, Toegankelijkheid en Natuurlijkheid. Samenvatting van de T2015-rapportage.

Beukema, J.J. (1993). Successive changes in distribution patterns as an adaptive strategy in the bivalve Macoma balthica (L.) in the Wadden Sea. Helgolander Meeresuntersuchungen, 47: 287-304.

Bouma, H., J.M.C. Duiker, P.P. de Vries, P.M.J. Herman (1998). Ecomorfologie op de Plaat van Baarland. De invloed van substraatdynamiek, - samenstelling en hoogteligging op de vestiging en handhaving van het Nonnetje en de Kokkel op de plaat van Baarland. Werkdocument RIKZ/OS$98.881 x$

Craeymeersch, J., \& V. Escaravage (2014). Perceel Benthos. PMR Monitoring natuurcompensatie Voordelta. Eindrapport 1e fase 2009-2013 deel B. . In: T. Prins and G. van der Kolff. Delft D (ed) Deltares rapport 1200672 -ZKS-0043.

Craeymeersch, J.A., M.A. Faasse, H. Gheerardyn, K. Troost, R. Nijland, A. Engelberts, K.J. Perdon, D. van den Ende, J. van Zwol. (2019). First records of the dwarf surf clam Mulinia lateralis (Say, 1822) in Europe. Marine Biodiversity Records. 12. 1-11.

Dam, G., P. van de Rest (2015). Buitendijks Natuurherstel voor het projectgebied Bath. SVASEK rapport

Jaspers, H., Buchoic, A., Verduin, E. (2018). Toetsing Buitendijkse Maatregelen projectgebied Bath aan de Wet natuurbescherming. SWECO rapport SWNL0225627.

Kattenwinkel, L. (2019). Brakwatercorbula in de Westerschelde: Potamocorbula amurensis (Schrenck, 1861) een nieuwe exoot. 't Heelblaadje 36(2): 20-23

LNV (2005) Natuurprogramma Westerschelde. Verantwoording realisering (minimaal) 600 ha estuariene nieuwe natuur en de relatie met de instandhoudingsdoelstellingen Vogel - en Habitatrichtlijn. Ministerie van Landbouw, Natuur en Voedselkwaliteit, 15 september 2005, DRZ-35311.

VLIZ Alien Species Consortium (2011). Oostzeegroenworm - Marenzelleria neglecta. Niet-inheemse soorten van het Belgisch deel van de Noordzee en aanpalende estuaria. Vlaams Instituut voor de Zee (VLIZ). Geraadpleegd op 28-04-2020. Beschikbaar op http://www.vliz.be/wiki/Lijst_niet-inheemse_soorten_Belgisch_deel_Noordzee_en_ aanpalende_estuaria

Wiesenborn, L., J. van Dalen, B. Walles, T. Ysebaert, J. van der Werf, L. de Vet, T. van Ooijen, J. Salvador de Paiva, T. Bouma (2019). Buitendijkse maatregelen Knuitershoek en Baalhoek, voortgangsrapportage 2 (2017-2018-2019). NIOZ report.

Ysebaert, T., E. Brummelhuis (2016). Ecomorfologische quicksan slikken van Bath. IMARES Wageningen UR rapport. 


\section{Bijlage 1 Coördinaten bemonsteringslocaties}

Tabel 3. Coördinaten van de 44 bemonsterslocaties op de slikken bij Bath. Per locatie staat de bijbehorende raai (zie Figuur 4) en droogvalduur (dvd) weergegeven. RDx en RDy staan in het rijksdriehoekcoördinatenstelsel, Lat en Lon in het WGS84 coördinatenstelsel.

\begin{tabular}{|c|c|c|c|c|c|c|}
\hline Raai & dvd & RDx & Rdy & Lat & Lon & code \\
\hline 1 & 10 & 70466.65 & 379189 & 51.39543 & 4.172389 & 11010 \\
\hline 1 & 20 & 70451.1 & 379211.4 & 51.39563 & 4.17216 & 12020 \\
\hline 1 & 40 & 70386.02 & 379305 & 51.39646 & 4.171203 & 14040 \\
\hline 1 & 50 & 70360.43 & 379341.8 & 51.39679 & 4.170826 & 15050 \\
\hline 1 & 70 & 70254.86 & 379493.7 & 51.39814 & 4.169273 & 17070 \\
\hline 1 & 80 & 70176.03 & 379607.2 & 51.39915 & 4.168113 & 18080 \\
\hline 2 & 10 & 70711.99 & 379370.4 & 51.3971 & 4.17587 & 21010 \\
\hline 2 & 20 & 70647.15 & 379462.5 & 51.39792 & 4.174917 & 22020 \\
\hline 2 & 40 & 70618.46 & 379503.2 & 51.39828 & 4.174495 & 24040 \\
\hline 2 & 50 & 70602.96 & 379525.6 & 51.39848 & 4.174267 & 25050 \\
\hline 2 & 50 & 70557.56 & 379499.1 & 51.39823 & 4.173621 & 25250 \\
\hline 2 & 50 & 70513.52 & 379472.3 & 51.39798 & 4.172995 & 25150 \\
\hline 2 & 50 & 70647.17 & 379549 & 51.39869 & 4.174896 & 25350 \\
\hline 2 & 50 & 70691.64 & 379571.8 & 51.39891 & 4.17553 & 25450 \\
\hline 2 & 70 & 70529.12 & 379630.1 & 51.39941 & 4.173181 & 27070 \\
\hline 2 & 80 & 70430.07 & 379770.8 & 51.40066 & 4.171724 & 28080 \\
\hline 3 & 10 & 70974.58 & 379510.3 & 51.3984 & 4.17961 & 31010 \\
\hline 3 & 20 & 70930.83 & 379589.4 & 51.3991 & 4.178963 & 32020 \\
\hline 3 & 40 & 70908.98 & 379629 & 51.39945 & 4.178639 & 34040 \\
\hline 3 & 50 & 70896.51 & 379652.2 & 51.39966 & 4.178455 & 35050 \\
\hline 3 & 70 & 70822.72 & 379785 & 51.40084 & 4.177363 & 37070 \\
\hline 3 & 80 & 70759.24 & 379899.8 & 51.40186 & 4.176423 & 38080 \\
\hline 4 & 10 & 71792.57 & 379818.3 & 51.40129 & 4.191291 & 41010 \\
\hline 4 & 20 & 71786.33 & 379850.8 & 51.40158 & 4.191194 & 42020 \\
\hline 4 & 40 & 71777.26 & 379897.9 & 51.402 & 4.191052 & 44040 \\
\hline 4 & 50 & 71771.59 & 379926.2 & 51.40225 & 4.190964 & 45050 \\
\hline 4 & 70 & 71742.83 & 380077.1 & 51.4036 & 4.190515 & 47070 \\
\hline 4 & 80 & 71707.93 & 380258.7 & 51.40523 & 4.189971 & 48080 \\
\hline 5 & 10 & 72024.71 & 379838.5 & 51.4015 & 4.194622 & 51010 \\
\hline 5 & 20 & 72024.95 & 379866.5 & 51.40175 & 4.194619 & 52020 \\
\hline 5 & 40 & 72025.31 & 379908.8 & 51.40213 & 4.194614 & 54040 \\
\hline 5 & 50 & 72026.09 & 379940.4 & 51.40242 & 4.194618 & 55050 \\
\hline 5 & 50 & 71986.71 & 379939 & 51.4024 & 4.194053 & 55250 \\
\hline 5 & 50 & 71947.08 & 379934.9 & 51.40236 & 4.193484 & 55150 \\
\hline 5 & 50 & 72105.31 & 379938.1 & 51.40241 & 4.195757 & 55450 \\
\hline 5 & 50 & 72066.09 & 379939.6 & 51.40242 & 4.195193 & 55350 \\
\hline 5 & 70 & 72027.71 & 380190 & 51.40466 & 4.194583 & 57070 \\
\hline 5 & 80 & 72028.62 & 380297.1 & 51.40562 & 4.194571 & 58080 \\
\hline 6 & 10 & 72293.11 & 379819.9 & 51.40137 & 4.198483 & 61010 \\
\hline 6 & 20 & 72297.19 & 379848.6 & 51.40163 & 4.198535 & 62020 \\
\hline 6 & 40 & 72304.55 & 379900.2 & 51.4021 & 4.198629 & 64040 \\
\hline 6 & 50 & 72309.52 & 379936.2 & 51.40242 & 4.198692 & 65050 \\
\hline 6 & 70 & 72352.96 & 380239.5 & 51.40515 & 4.199245 & 67070 \\
\hline 6 & 80 & 72365.72 & 380328.9 & 51.40596 & 4.199408 & 68080 \\
\hline
\end{tabular}




\section{Bijlage 2 Conversiefactoren}

Tabel 4. Conversiefactoren voor het omzetten van natgewichten (wet weight (WW) in mg) naar asvrijdrooggewichten (ash-free dry weight (AFDW) in $\mathrm{mg}$ ). Per conversiefactor is aangegeven op hoeveel observaties de conversie is gebaseerd, de standard afwijking en in welk jaar dit bepaald is. Voor een aantal soorten was geen conversiefactor beschikbaar. Voor deze soorten staat aangegeven van welke andere soort een conversiefactor is geadopteerd.

\begin{tabular}{|c|c|c|c|c|c|}
\hline Taxa & $\begin{array}{c}\text { Conversiefactor } \\
\text { (AFDW in } \mathrm{mg} / \mathrm{WW} \text { in } \mathrm{mg} \text { ) }\end{array}$ & \# observaties & sd & jaar & opmerking \\
\hline Alitta succinea & 0.1144 & 97 & 0.0245 & 2011 & als Nereis succinea \\
\hline Aphelochaeta & 0.1268 & 2 & & & als Tharyx marioni \\
\hline Arenicola marina & 0.1446 & 18 & 0.0177 & 2011 & \\
\hline Bathyporeia pilosa & 0.1147 & & & & als Bathyporeia \\
\hline Bivalvia & 0.1367 & 10 & 0.022 & 2011 & \\
\hline Capitella & 0.1214 & 21 & 0.0093 & 2011 & als capitella capitata \\
\hline Carcinus maenas & 0.1296 & 21 & 0.0258 & 2011 & \\
\hline Caridea & 0.1399 & 144 & 0.0308 & 2011 & \\
\hline Cerastoderma edule & 0.0349 & 33 & 0.0085 & 2011 & \\
\hline Cirratulidae & 0.1268 & & & 2010 & \\
\hline Corophium volutator & 0.1012 & & & & als Corophium arenarium \\
\hline Crangon crangon & 0.1638 & 38 & 0.0184 & 2011 & \\
\hline Cyathura carinata & 0.1012 & & & & als Corophium arenarium \\
\hline Ensis & 0.0952 & 94 & 0.0221 & 2011 & \\
\hline Eteone & 0.1326 & 20 & 0.0209 & 2011 & \\
\hline Hediste diversicolor & 0.1144 & 97 & 0.0245 & 2011 & \\
\hline Heteromastus filiformis & 0.1205 & 19 & 0.0093 & 2011 & \\
\hline Hypereteone foliosa & 0.1326 & 20 & 0.0209 & 2011 & \\
\hline Idotea emarginata & 0.1382 & & & & als Idotea linearis \\
\hline Limecola balthica & 0.068 & 50 & 0.0135 & 2011 & \\
\hline Marenzelleria neglecta & 0.1296 & & & & als Marenzelleria \\
\hline Melita palmata & 0.1147 & & & & als Melita \\
\hline Microdeutopus & 0.1147 & 10 & 0.0075 & 2011 & \\
\hline Mulinia lateralis & 0.052 & & & & als Spisula \\
\hline Mya arenaria & 0.0888 & 110 & 0.0202 & 2011 & \\
\hline Nemertea & 0.1648 & 40 & 0.0257 & 2011 & \\
\hline Nephtys & 0.1243 & 62 & 0.018 & 2011 & \\
\hline Nereididae & 0.1296 & & & & als Nereis \\
\hline Oligochaeta & 0.1111 & 14 & & 2009 & \\
\hline Peringia ulvae & 0.0728 & 20 & 0.0065 & 2011 & \\
\hline Petricolaria pholadiformis & 0.061 & 14 & 0.0153 & 2011 & \\
\hline Polydora cornuta & 0.1296 & 32 & 0.0161 & 2011 & \\
\hline Potamocorbula amurensis & 0.0486 & & & & als Corbula gibba \\
\hline Pygospio elegans & 0.1296 & 32 & 0.0161 & 2011 & \\
\hline Scrobicularia plana & 0.0604 & 12 & 0.0201 & 2011 & \\
\hline Streblospio benedicti & 0.1296 & 32 & 0.0161 & 2011 & \\
\hline
\end{tabular}




\section{Bijlage 3 Verspreidingskaarten dichtheden en biomassa per soort}

Verspreidingskaarten van dichtheden (individuen per $\mathrm{m}^{2}$ ) en biomassa ( $\mathrm{g}$ AFDW per $\mathrm{m}^{2}$ ) per soort. Verspreidingskaarten worden enkel getoond voor soorten die op meer dan 2 locaties voorkomen (met uitzondering van Petricolaria pholadiformis) en in dichtheden groter dan 84 individuen per $\mathrm{m}^{2}$.

Alitta succinea
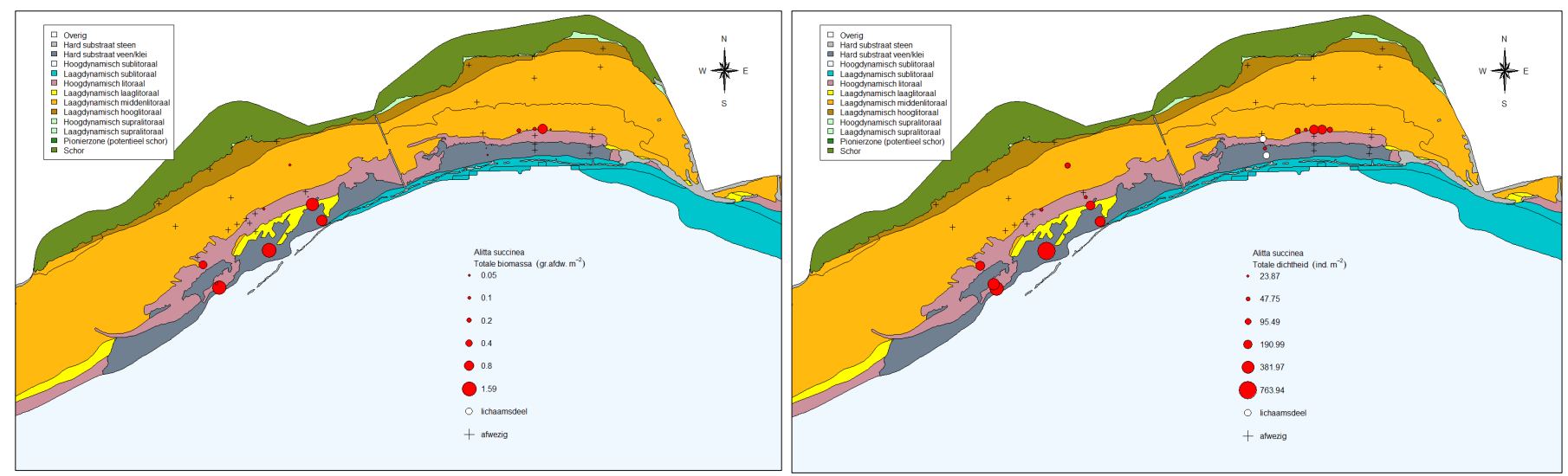

Cerasoderma edule
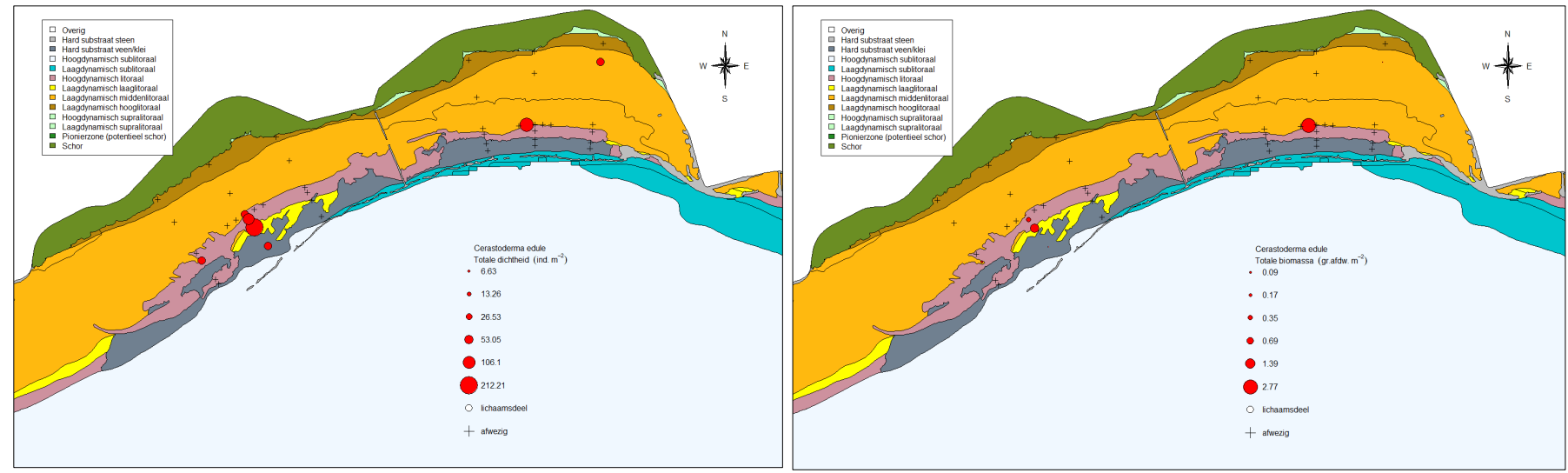

\section{Corophium volutator}
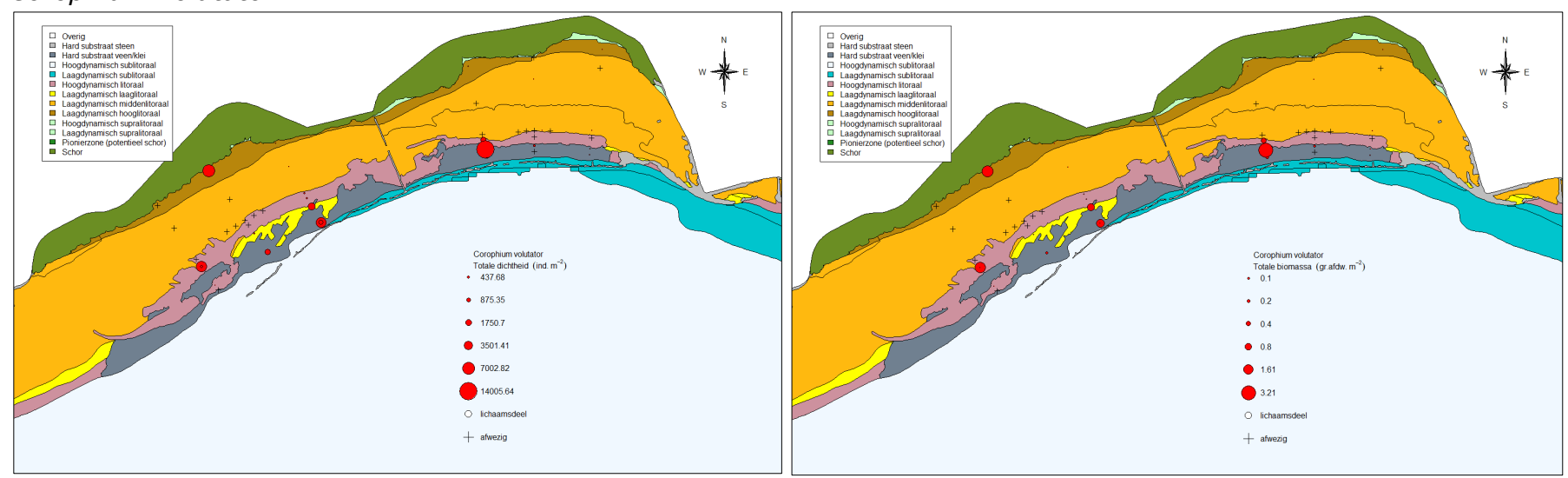

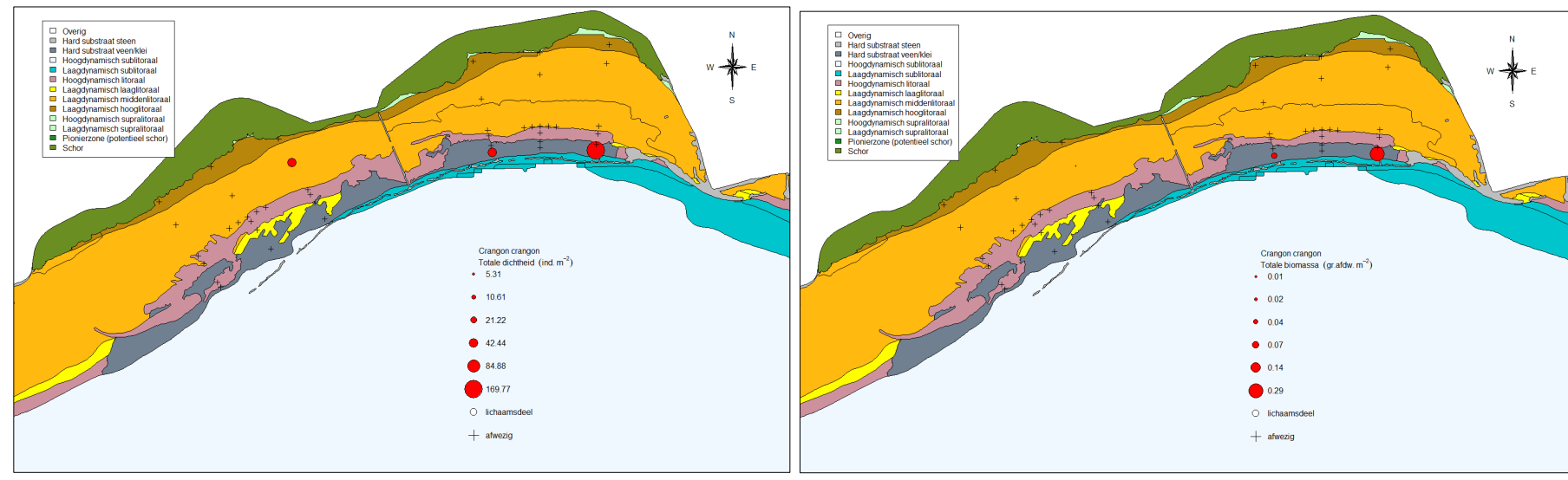

\section{Cyathura carinata}

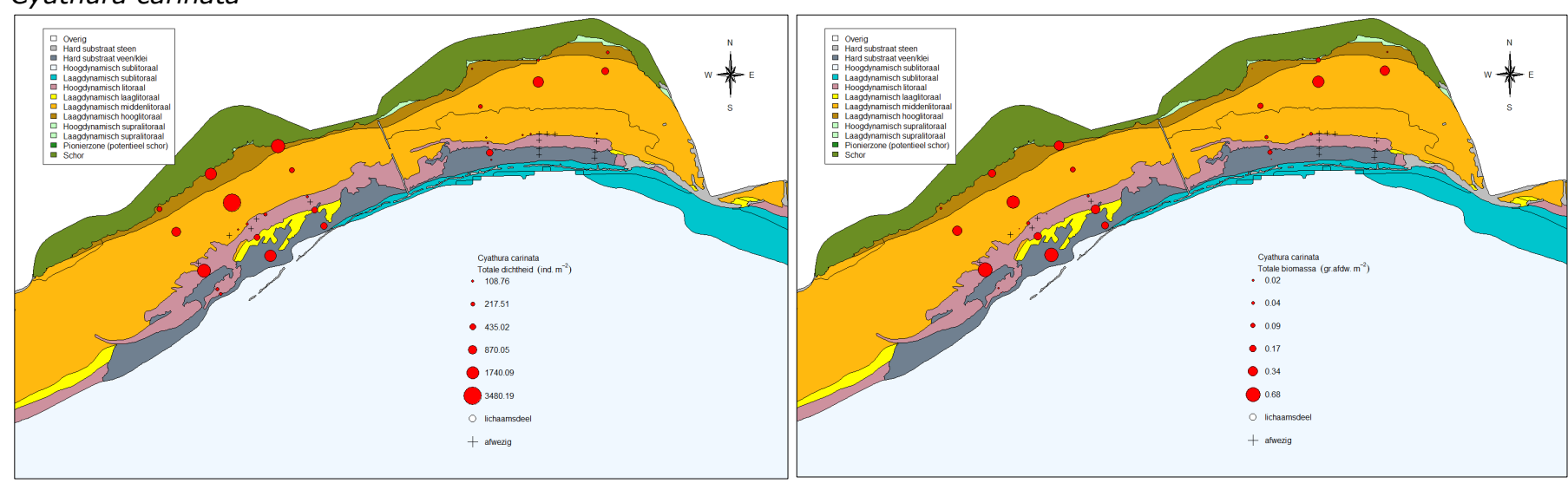

\section{Easone}

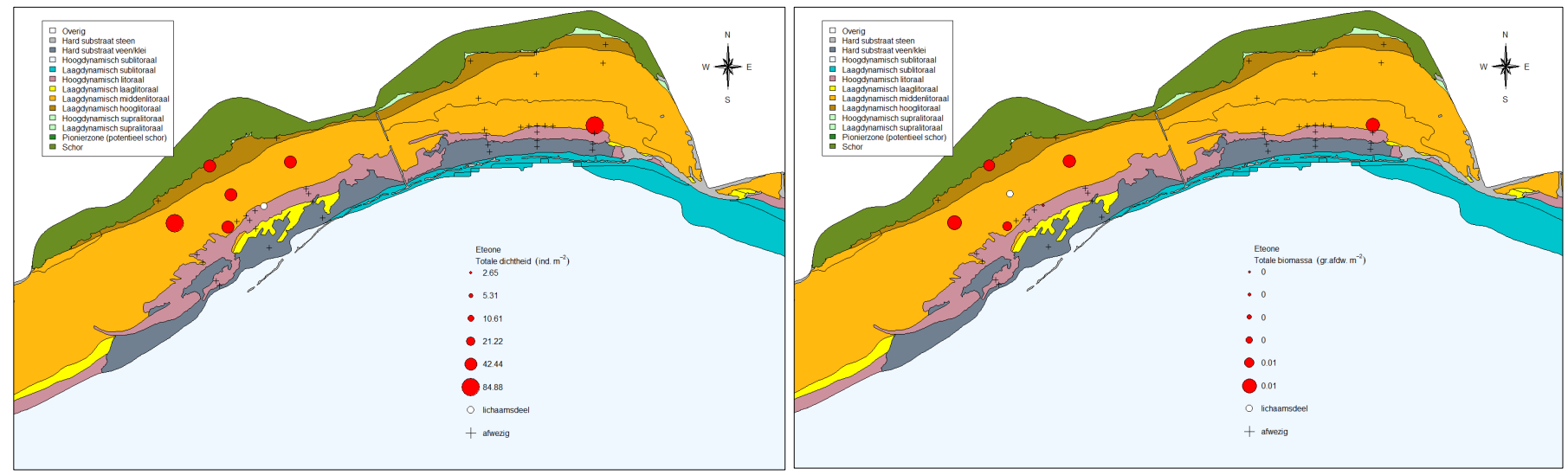

\section{Hediste diversicolor}

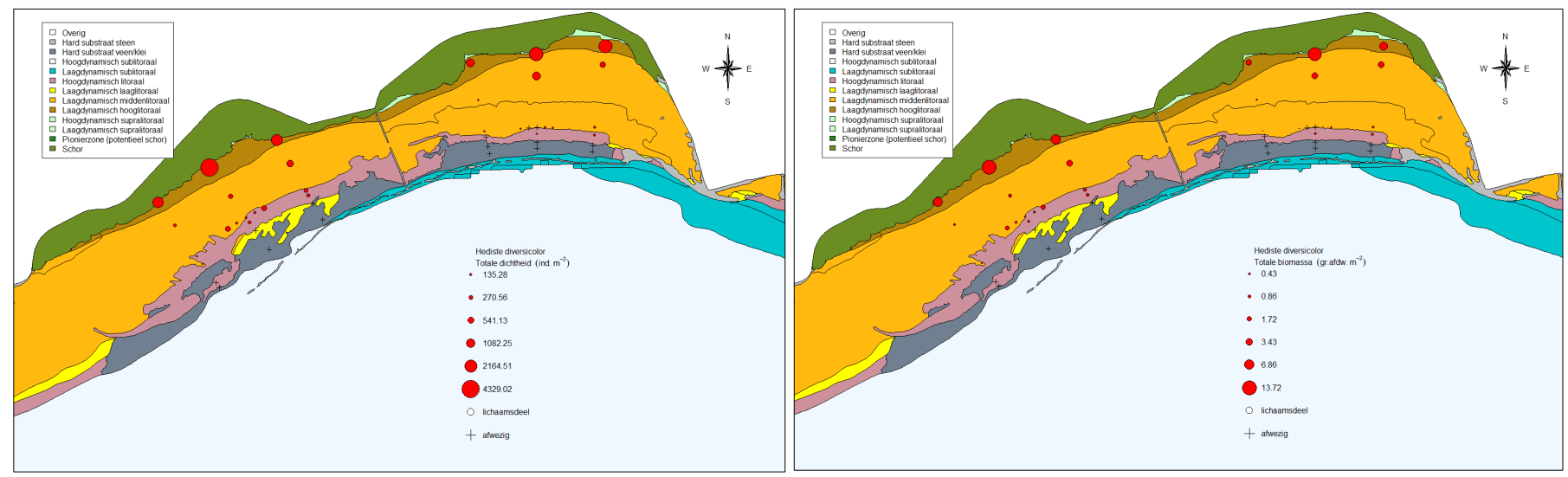



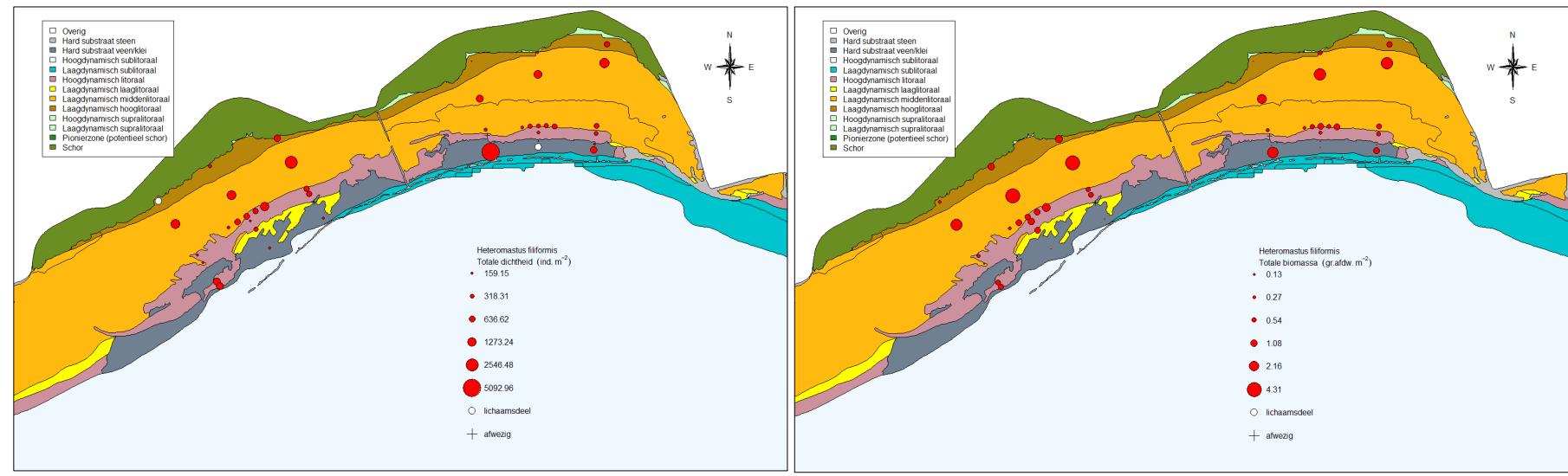

\section{Hypereteone foliosa}
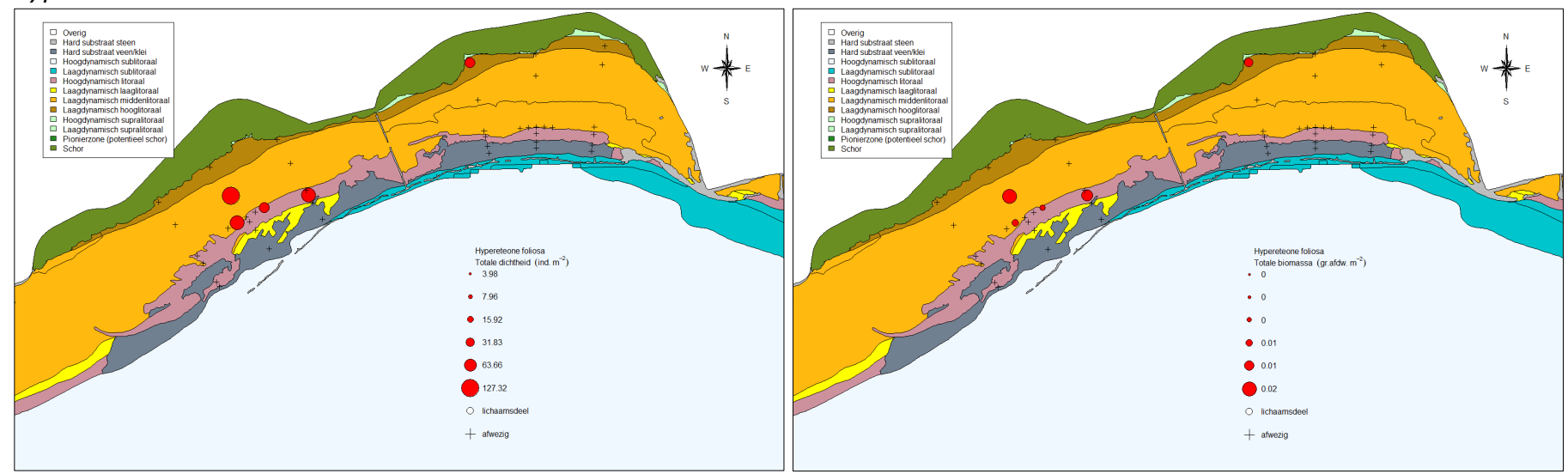

\section{Limecola Balthica}
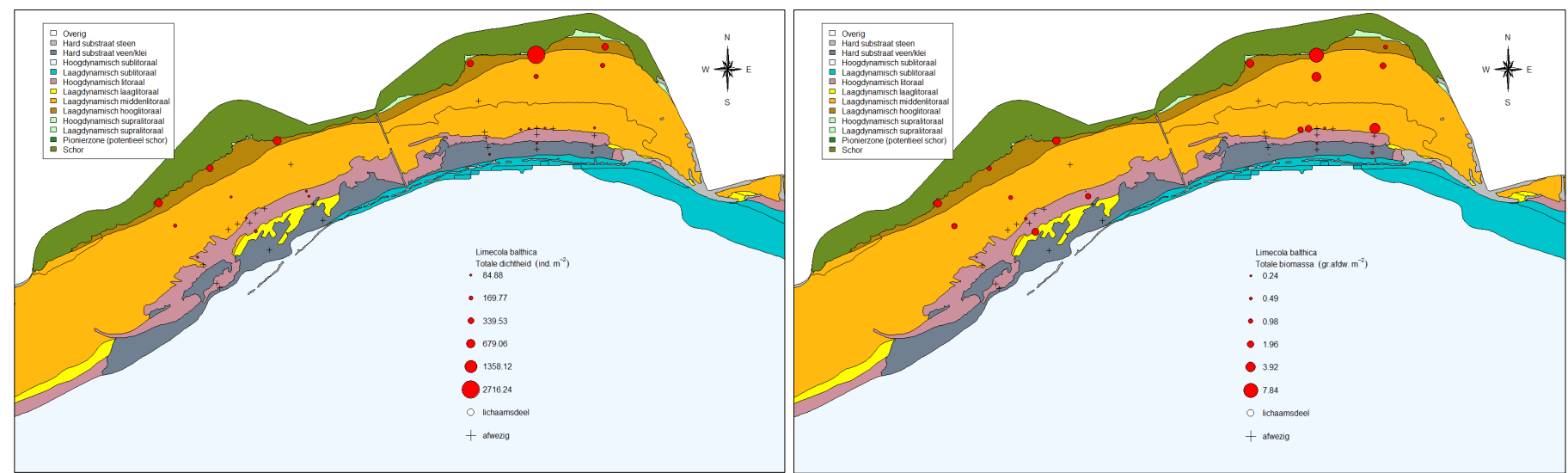

\section{Marenzelleria neglecta}
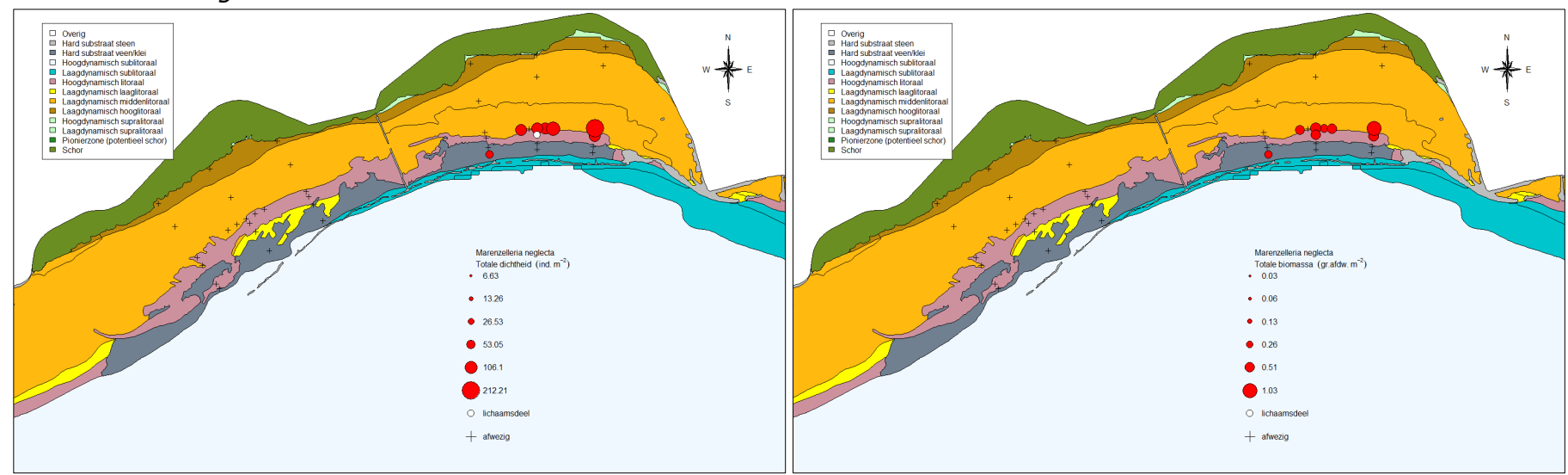

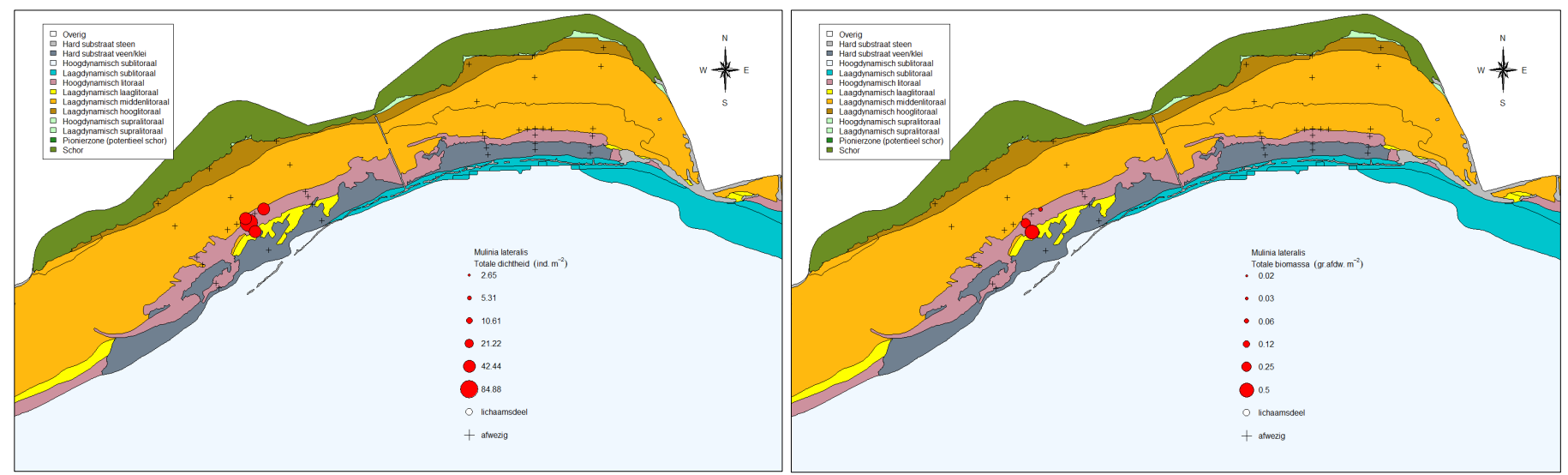

\section{Mya arenaria}
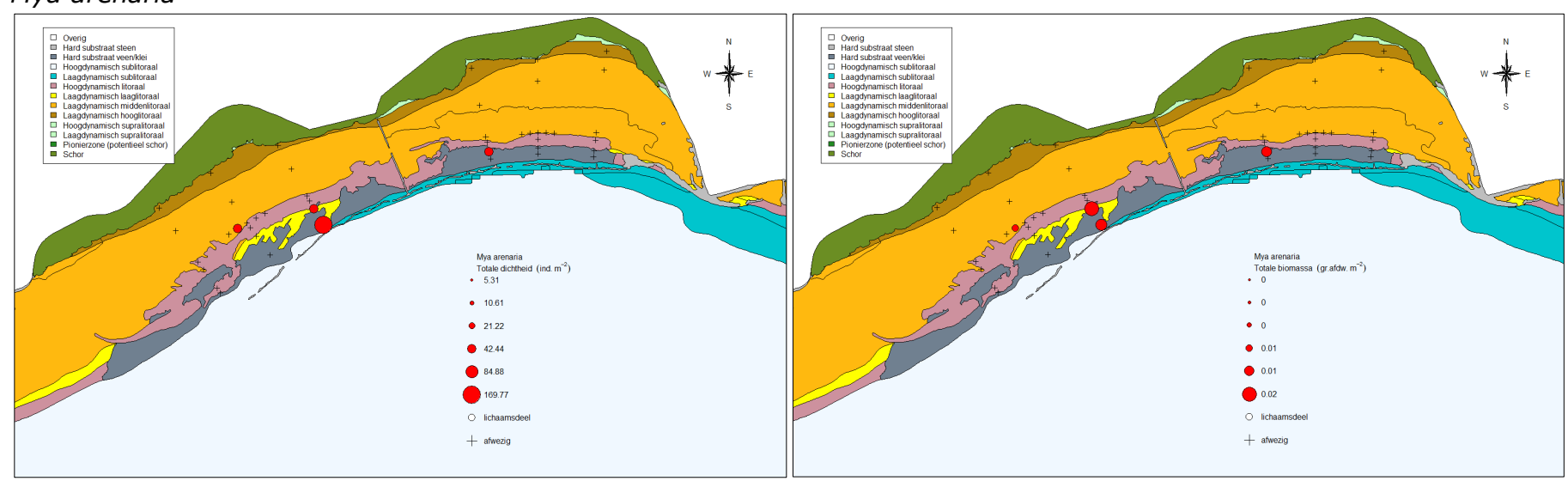

\section{Nereididae}
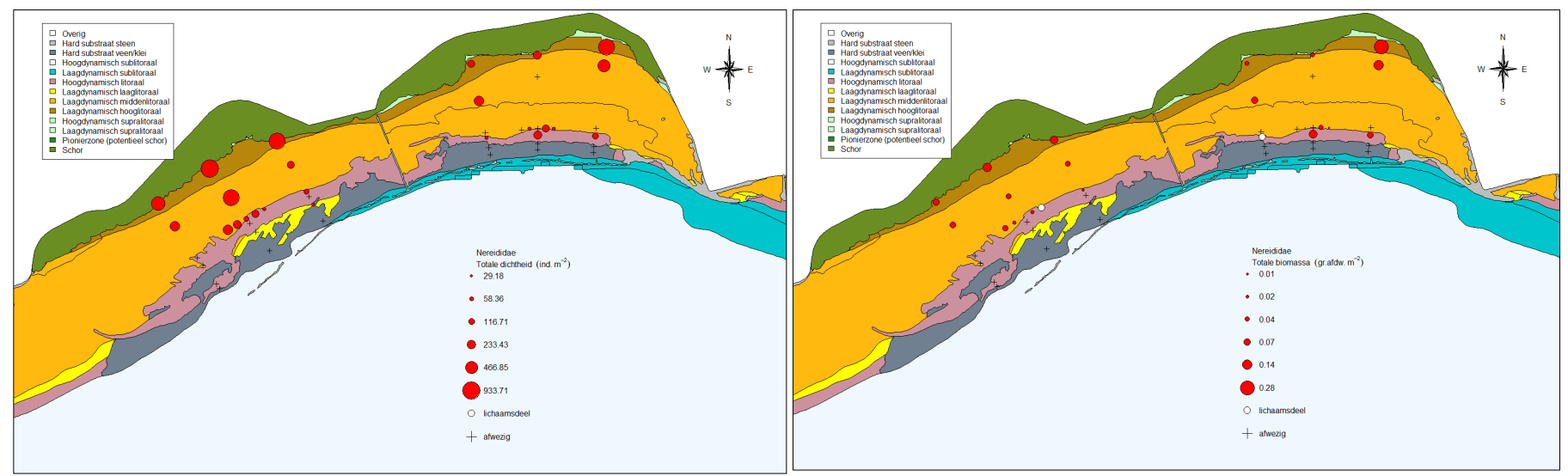

\section{Oligochaeta}
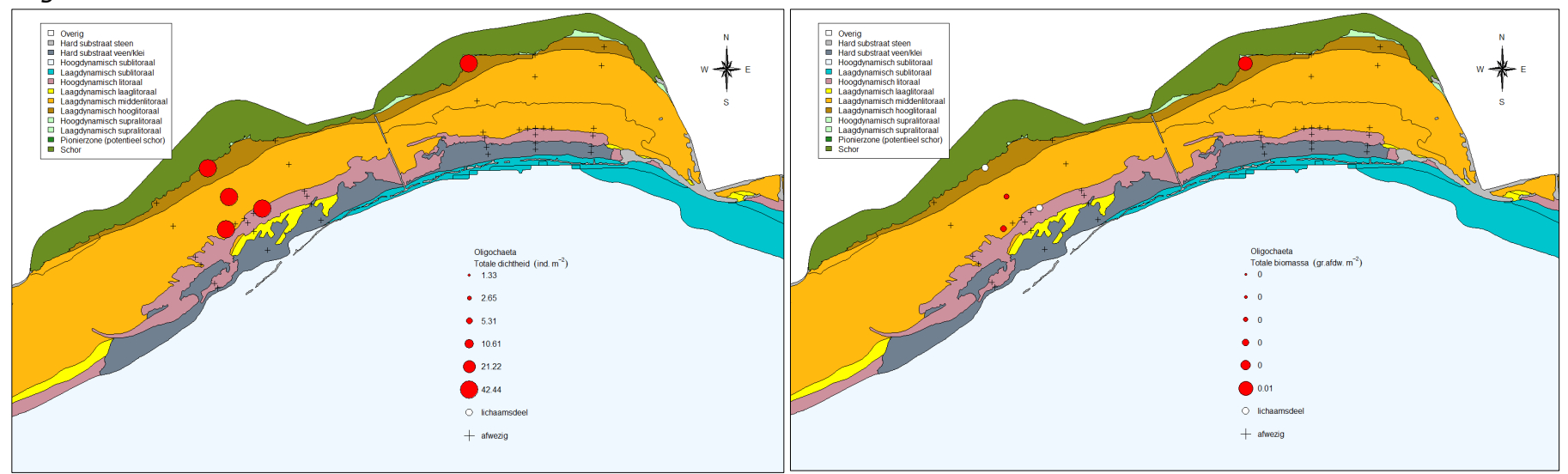
Peringia ulvae
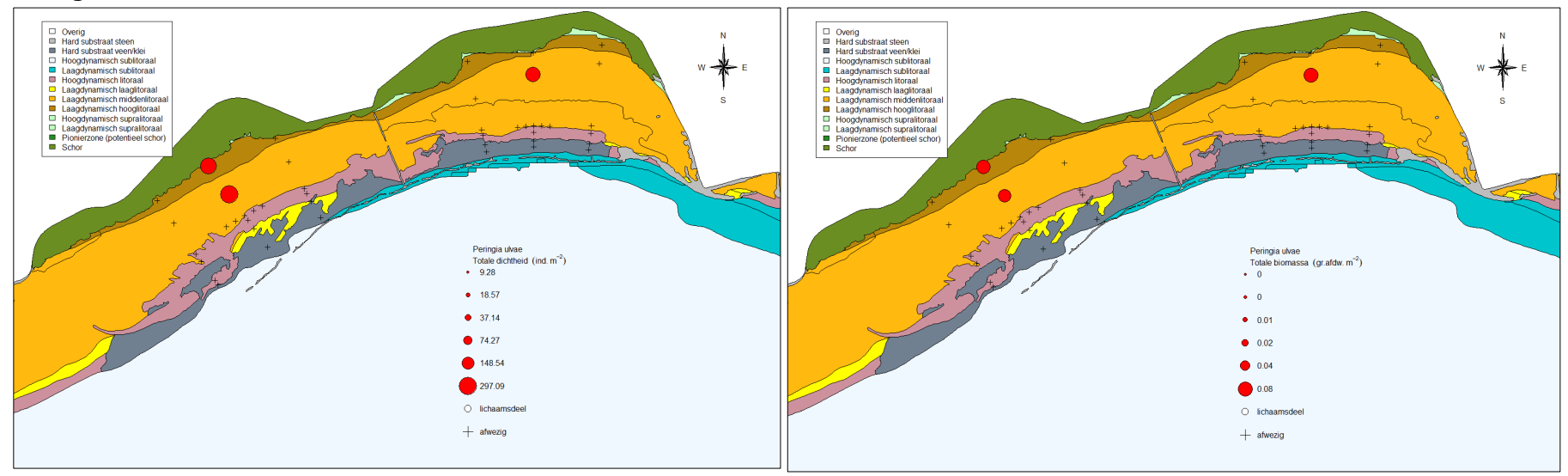

\section{Petricolaria pholadiformis}
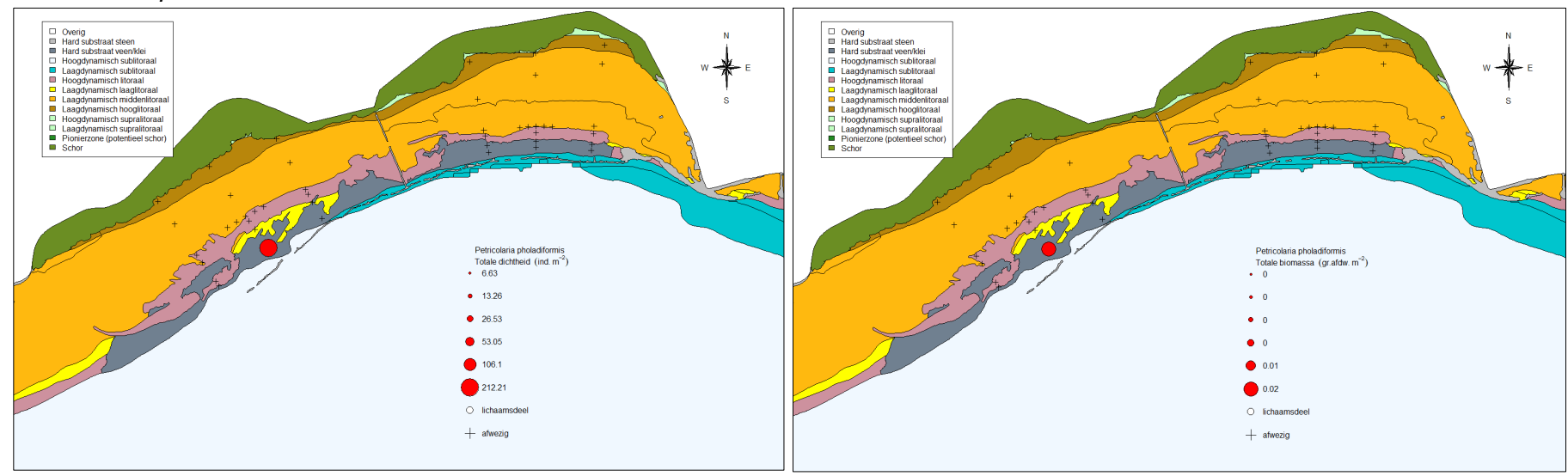

\section{Polydora cornuta}
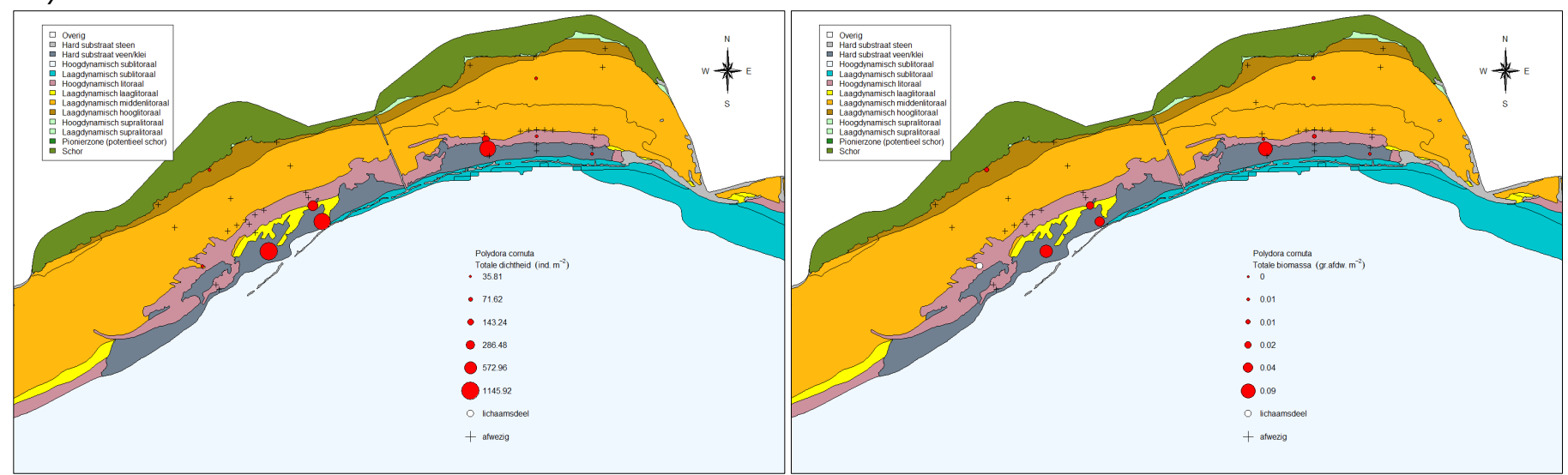

\section{Potamocorbula amurensis}
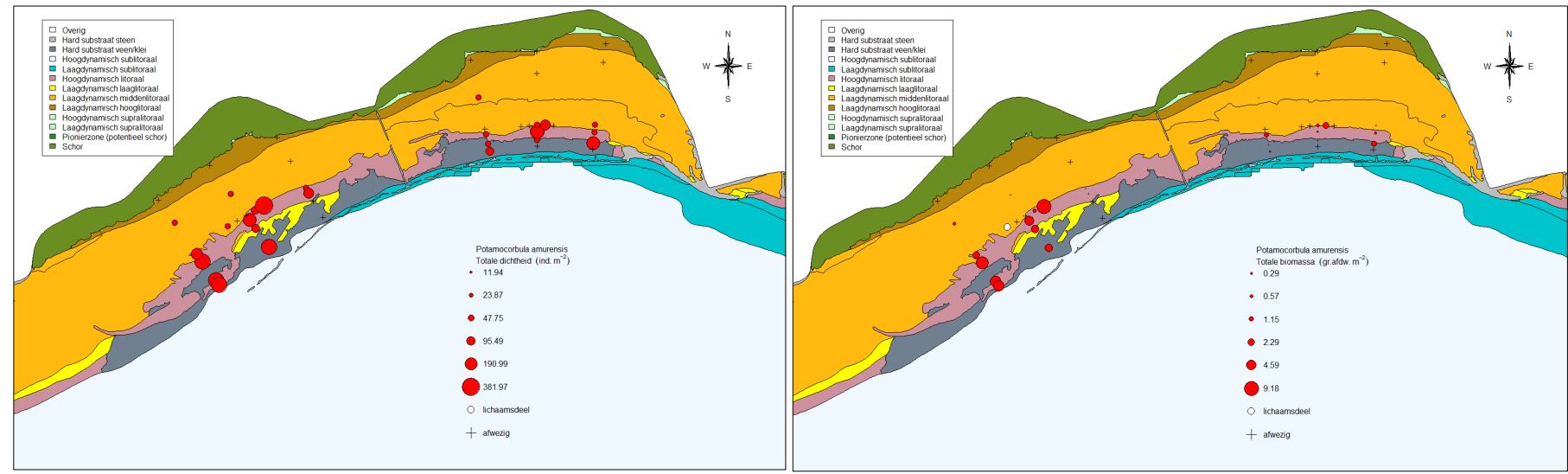


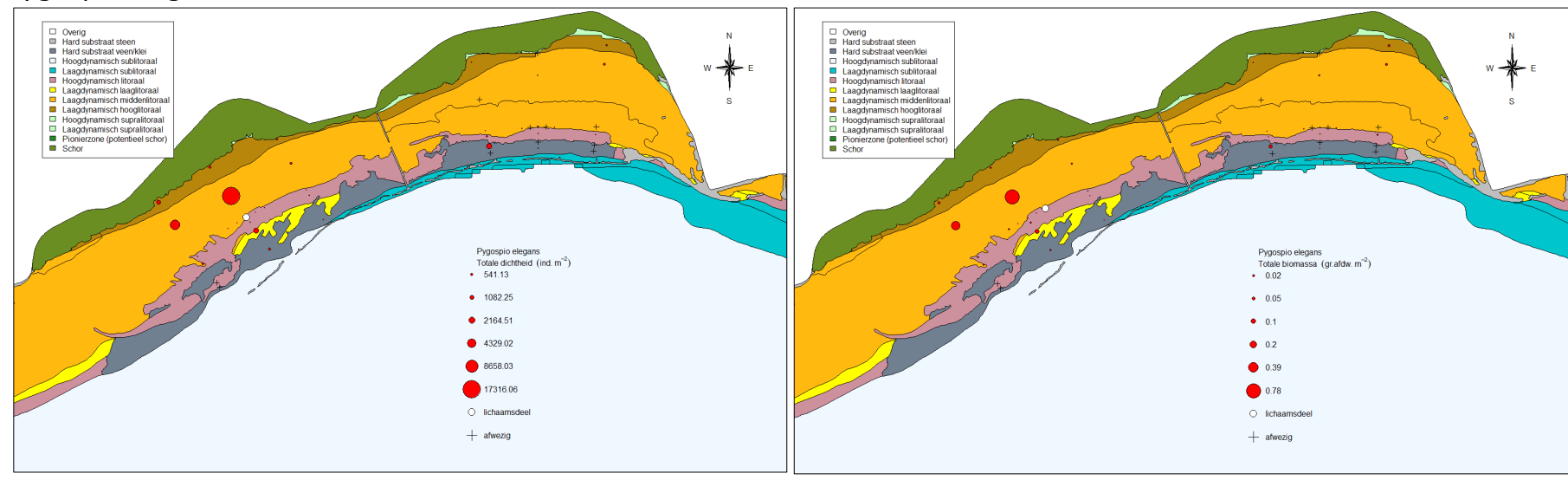

\section{Scrobicularia plana}

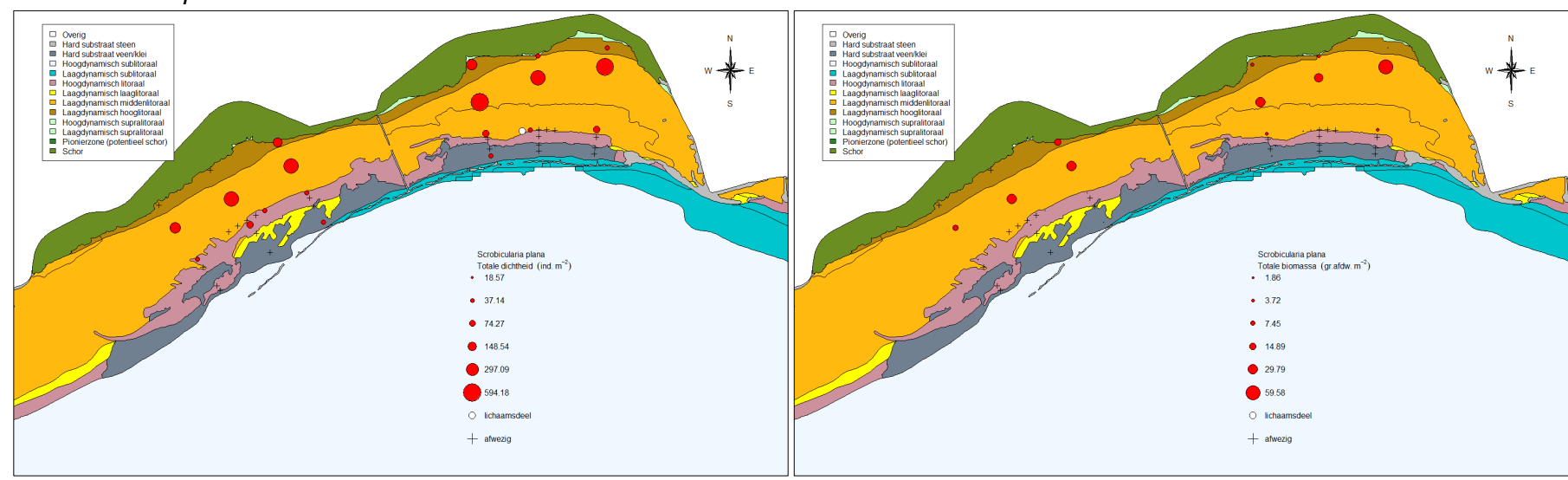

\section{Streblospio benedicti}

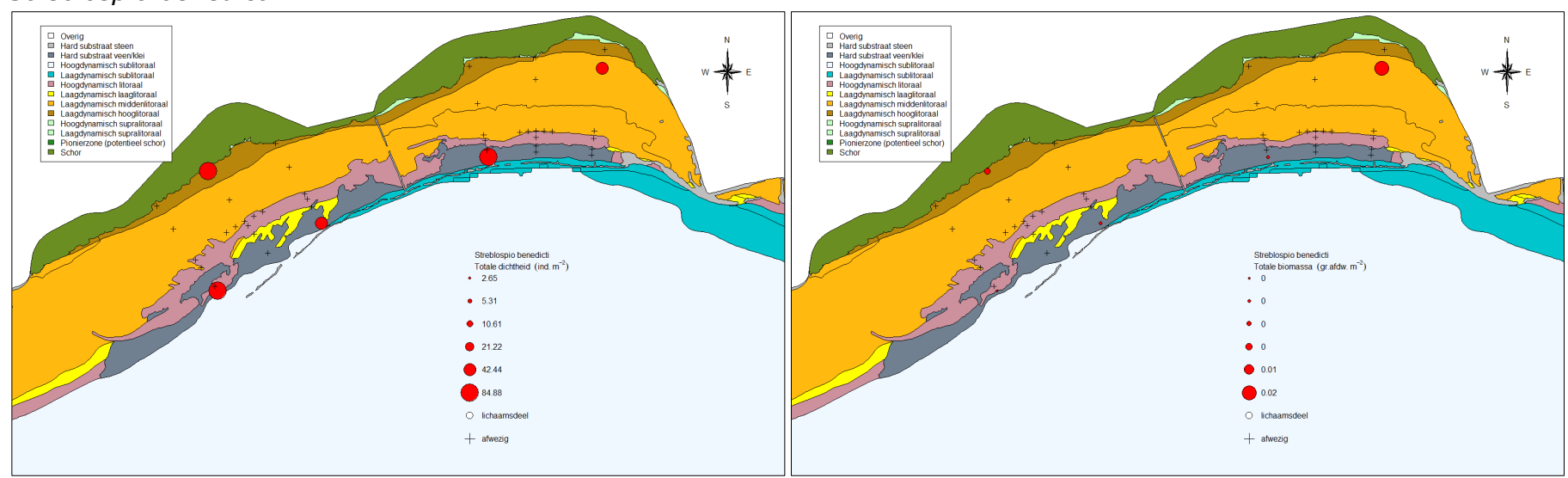




\section{Bijlage 4 Verspreidingskaart grof, middel fijn, fijn en zeer fijn sediment.}

Percentage zeer fijn zand per bemonsterstation en per droogvalduur. Witte stippen geven aan waar geen monster genomen zijn (raai 1 , dvd $10 \%$ en $20 \%$ en raai 5 , dvd $40 \%$ ).
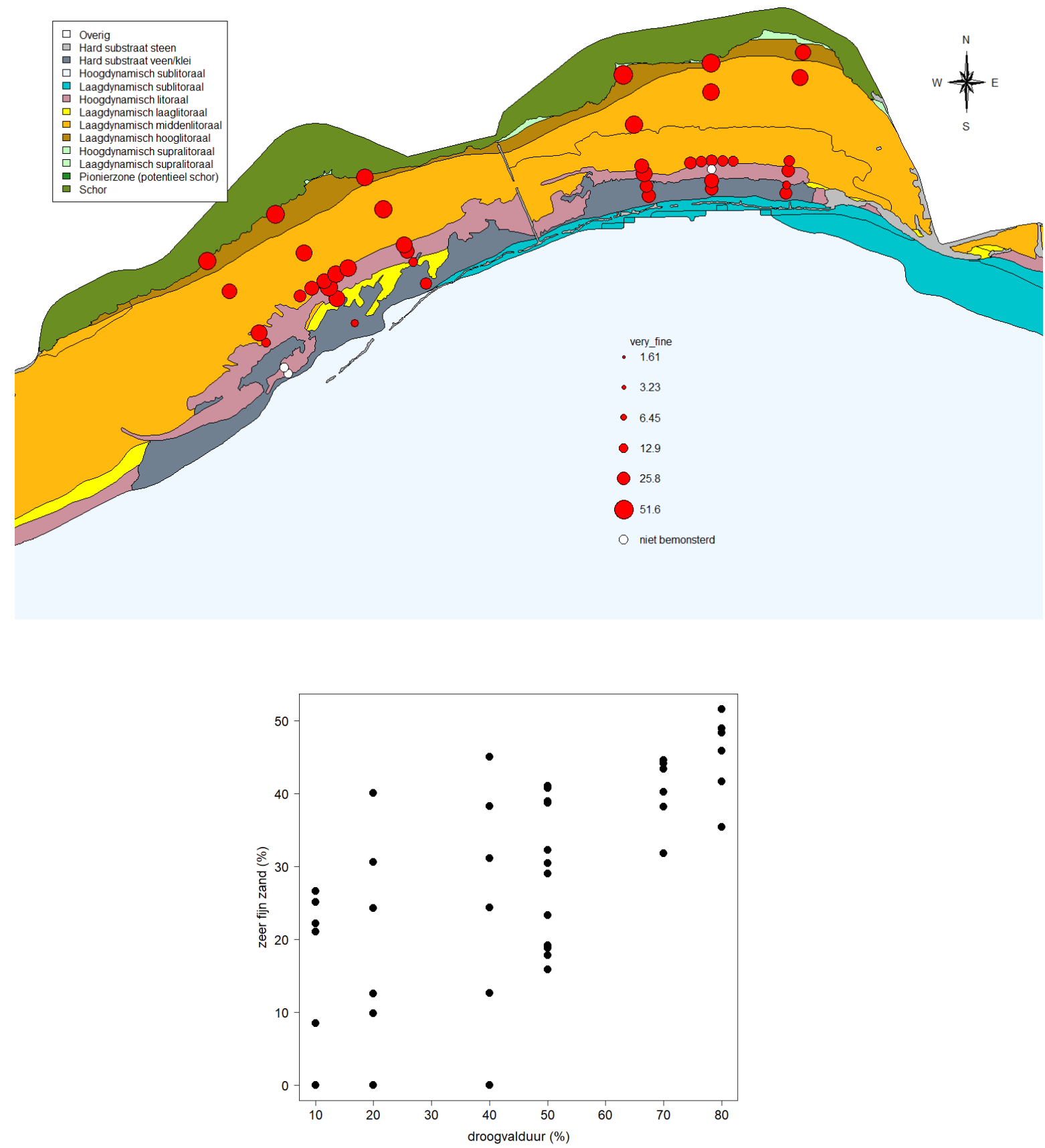
Percentage fijn zand per bemonsterstation en per droogvalduur. Witte stippen geven aan waar geen monster genomen zijn (raai 1 , dvd $10 \%$ en $20 \%$ en raai 5 , dvd $40 \%$ ).
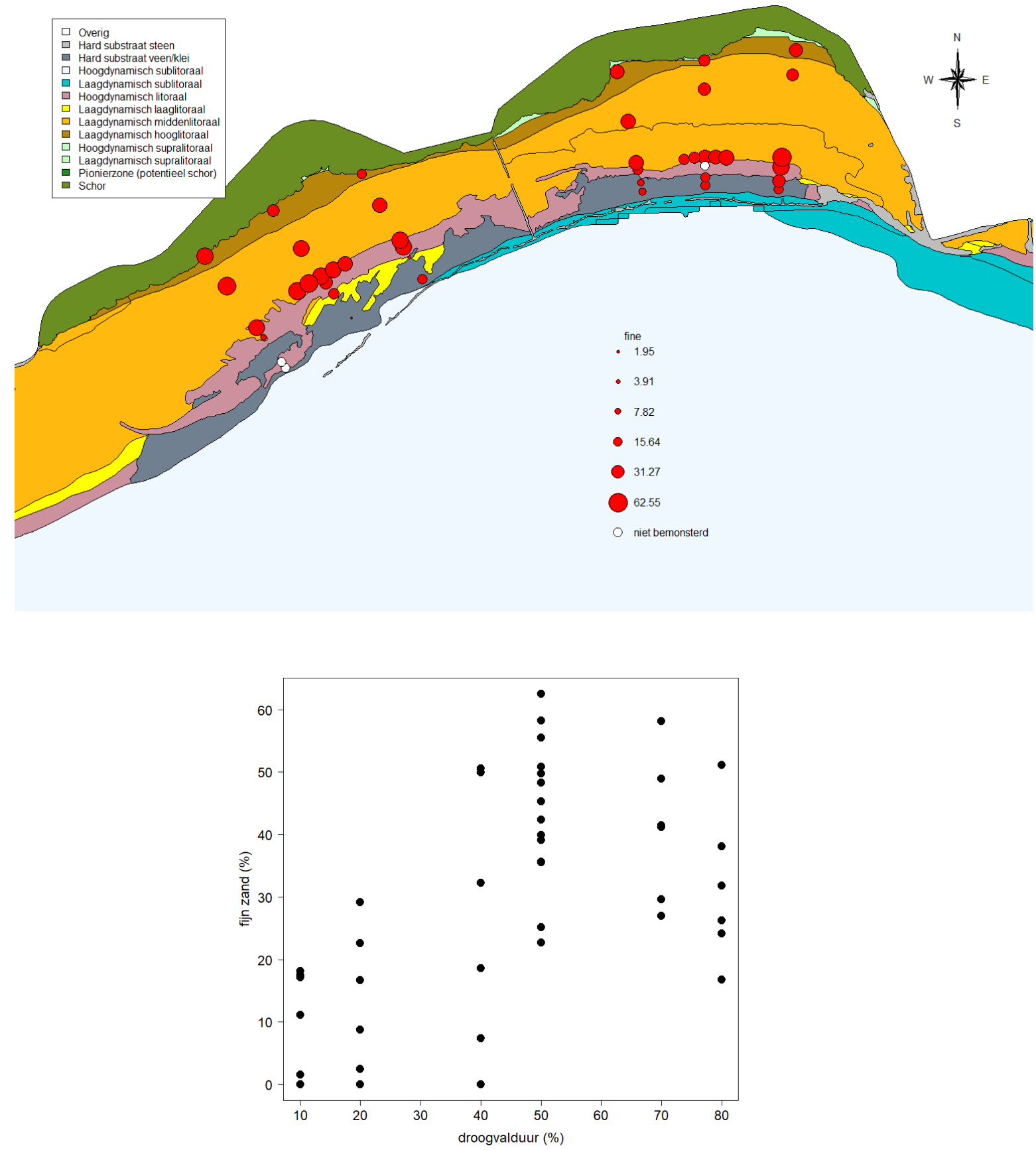
Percentage midden fijn zand per bemonsterstation en per droogvalduur. Witte stippen geven aan waar geen monster genomen zijn (raai 1 , dvd $10 \%$ en $20 \%$ en raai 5 , dvd $40 \%$ ).
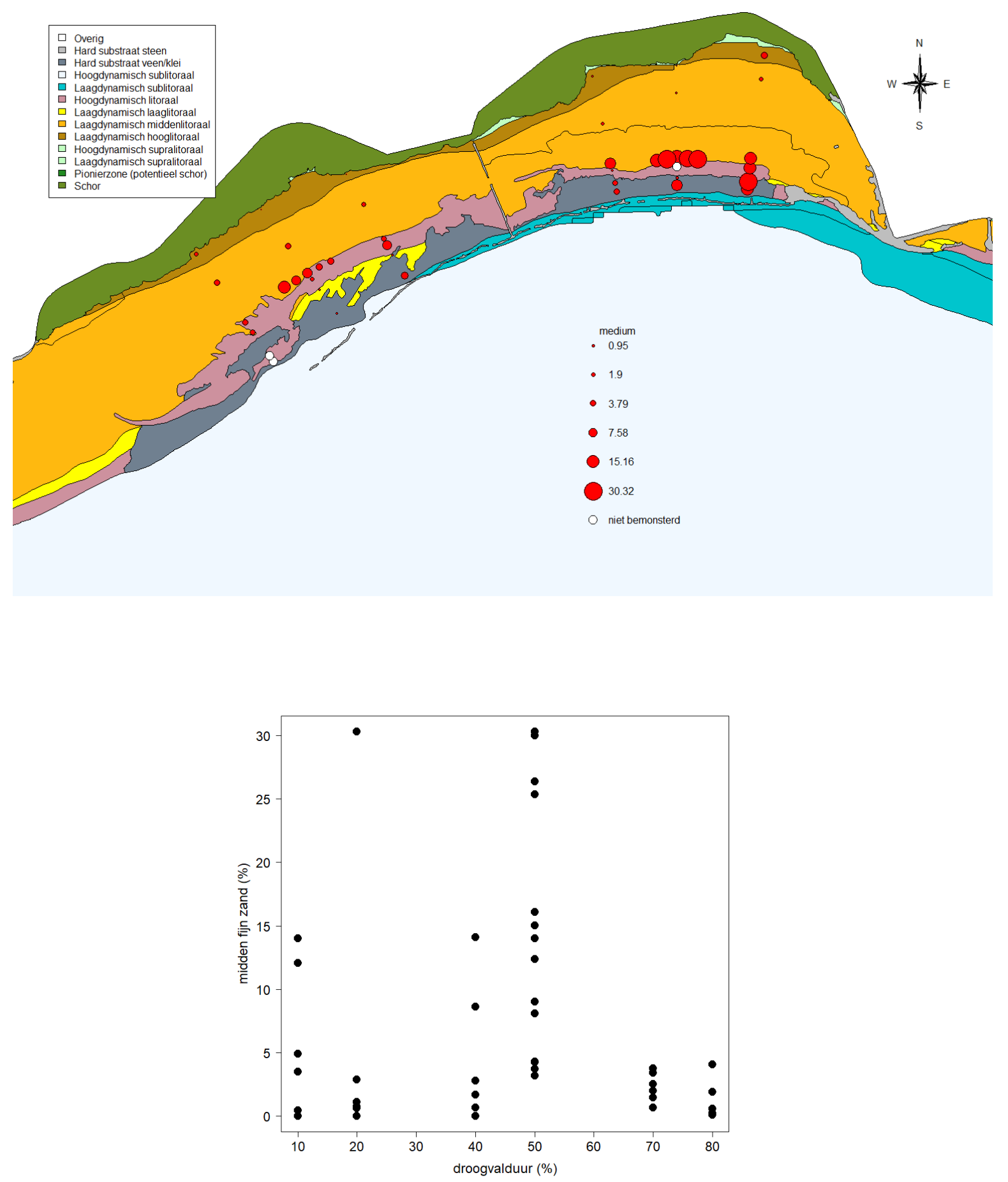
Percentage grof sediment per bemonsterstation. Witte stippen geven aan waar geen monster genomen zijn (raai 1 , dvd $10 \%$ en $20 \%$ en raai 5 , dvd $40 \%$ ), kruisjes waar geen grof sediment aanwezig was.

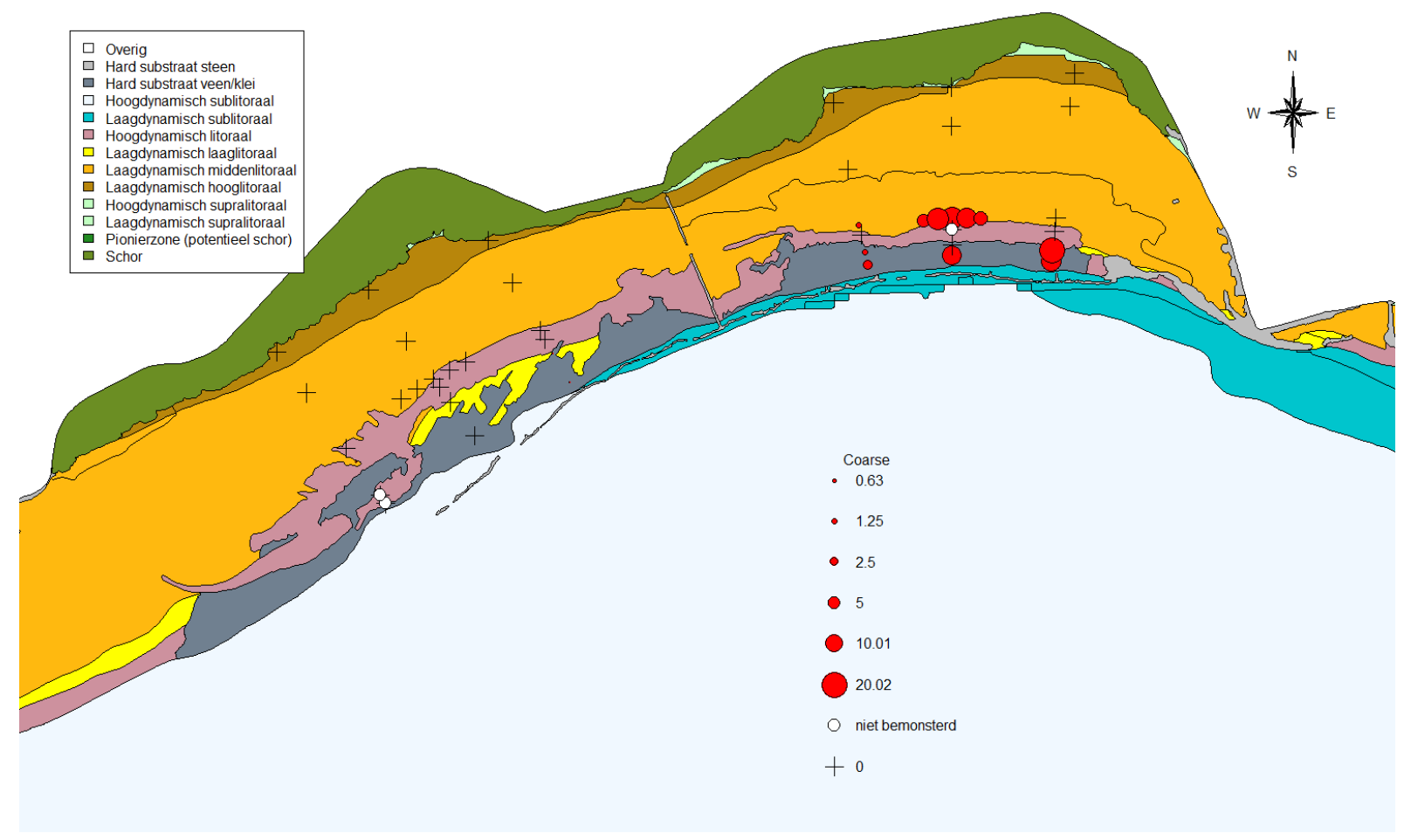




\section{Verantwoording}

Rapport C050/20

Projectnummer: 4313100105

Dit rapport is met grote zorgvuldigheid tot stand gekomen. De wetenschappelijke kwaliteit is intern getoetst door een collega-onderzoeker en het verantwoordelijk lid van het managementteam van Wageningen Marine Research

Akkoord:

Johan Craeymeersch

Senior onderzoeker

Handtekening:

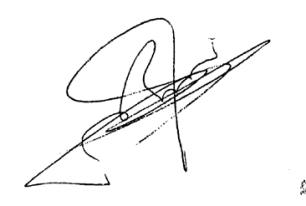

Datum:

5 juni 2020

Akkoord:

Drs. Jakob Asjes

MT lid Integratie

Handtekening:

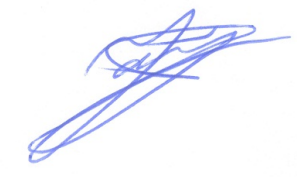

Datum:

5 juni 2020 
Wageningen Marine Research

T: +31(0)317480900

E: marine-research@wur.nl

www.wur.nl/marine-research

Bezoekers adres:

- Ankerpark 271781 AG Den Helder

- Korringaweg 7, 4401 NT Yerseke

- Haringkade 1, 1976 CP IJmuiden
Wageningen Marine Research levert met kennis, onafhankelijk wetenschappelijk onderzoek en advies een wezenlijke bijdrage aan een duurzamer, zorgvuldiger beheer, gebruik en bescherming van de natuurlijke rijkdommen in zee-, kust- en zoetwatergebieden.

Wageningen Marine Research is onderdeel van Wageningen University \& Research. Wageningen University \& Research is het samenwerkingsverband tussen Wageningen University en Stichting Wageningen Research en heeft als missie: 'To explore the potential of nature to improve the quality of life' 